Estela Waksberg Guerrini

\title{
AÇÕES AFIRMATIVAS PARA NEGROS NAS UNIVERSIDADES PÚBLICAS BRASILEIRAS: O CASO DO TRIBUNAL DE JUSTIÇA DO RIO DE JANEIRO (2001 - 2008)
}

Dissertação de mestrado

Orientadora: Professora Dra. Eunice Aparecida de Jesus Prudente

Faculdade de Direito da Universidade de São Paulo São Paulo

2010 
Estela Waksberg Guerrini

\section{AÇÕES AFIRMATIVAS PARA NEGROS NAS \\ UNIVERSIDADES PÚBLICAS BRASILEIRAS: O CASO DO \\ TRIBUNAL DE JUSTIÇA DO RIO DE JANEIRO (2001 - 2008)}

Dissertação apresentada à Faculdade de Direito da USP, na área de concentração de Direitos Humanos, como requisito para obtenção do título Mestre.

Orientadora: Professora Doutora Eunice Aparecida de Jesus Prudente 


\section{AÇÕES AFIRMATIVAS PARA NEGROS NAS \\ UNIVERSIDADES PÚBLICAS BRASILEIRAS: O CASO DO \\ TRIBUNAL DE JUSTIÇA DO RIO DE JANEIRO (2001 - 2008)}

Dissertação apresentada à Faculdade de Direito da USP, na área de concentração de Direitos Humanos, como requisito para obtenção do título Mestre.

Orientadora: Professora Doutora Eunice Aparecida de Jesus Prudente

Aprovada em:

Banca Examinadora

Prof. Dr.

Instituição

Assinatura

Prof. Dr.

Instituição

Assinatura

Prof. Dr.

Instituição

Assinatura 
Ao meu marido, Rafael, por ouvir, por falar, por construir mais uma coisa junto comigo 


\section{AGRADECIMENTOS}

Agradeço à minha irmã, Ana, e ao meu marido, Rafael, pela paciência e pela atenção na elaboração desta dissertação, por me trazerem ideias, por dialogarem, por me ensinarem. À minha irmã, também por ter sido sempre a professora número um. Ao meu marido, pelos gráficos, pela convivência, por cozinhar para mim, por me dar um ambiente tranquilo para estudar, por cuidar de mim todos os dias.

Aos meus pais, Sara e Irineu, pelo amor e constante apoio, em todos os infinitos sentidos.

À minha orientadora, Eunice, pela oportunidade.

À turma da pós-graduação de direitos humanos, pelo espaço de reflexão.

Aos amigos queridos: Akemi Kamimura, Camila Perruso, Fernanda Fernandes e Julia Neiva, pelos anos de discussão sobre direitos humanos; Paulo Macedo, por ter sido a primeira pessoa a me fazer refletir sobre as ações afirmativas para negros, e Rafael Alves e Gustavo Bambini, pelas adoráveis conversas; a Carolina Marinho e Daniela Trettel, pelo generoso empréstimo dos livros e textos; Mariana Ferraz, pelas risadas; Fernanda Pellegrini, Débora Doimo, Juliana Dias, Maria Jamile, Frederico Kling, Fernanda Yazbek e toda a turma, pelos papos e pela diversão; Maria Stella Fagundes, pela amizade eterna.

À Pipa, companheira de doze anos. 
Cher frère blanc,

Quand je suis né, j'étais noir, Quand j'ai grandi, j'étais noir, Quand je vais au soleil, je suis noir, Quand j'ai peur, je suis noir, Quand je suis malade, je suis noir... Quand je mourrai, je serai noir...

Tandis que toi, homme blanc...

Quand tu es né tu étais rose,

Quand tu as grandi, tu étais blanc, Quand tu vas au soleil, tu es rouge, Quand tu as froid, tu es bleu, Quand tu as peur, tu es vert, Quand tu es malade, tu es jaune, Quand tu mourras, tu seras gris... Et après cela, tu as le toupet de m'appeler Homme de couleur.

(Léopold SEDAR SENGHOR)

Os seres humanos são naturalmente diferentes quanto ao seu fenótipo étnico ou à sua conformação sexual. Nenhuma dessas diferenças deveria, em boa razão, implicar uma posição de desigualdade social. No entanto, é com base nelas que, desde sempre, uns se consideram superiores a outros

(Fabio Konder Comparato)

Do que temos medo? Das diferenças, ou das semelhanças escondidas atrás das diferenças?

(Kabengele Munanga) 


\section{RESUMO}

A presente dissertação teve como objeto o estudo do princípio da igualdade e das ações afirmativas. O objetivo específico foi o de investigar se nas decisões julgadas de 2001 a 2008 do Tribunal de Justiça do estado do Rio de Janeiro, o argumento racial foi mais utilizado que o argumento social. O recorte espacial se deu em função de esse estado ser o único a instituir reserva de vagas em suas universidades públicas por meio de lei estadual. O recorte temporal justifica-se pelo fato de o ano de 2001 ter sido praticamente o primeiro ano de vigência da primeira lei estadual, e o ano de 2008 ter sido o último ano de coleta de julgados na página eletrônica do Tribunal. O trabalho está dividido em duas partes: na primeira parte, foi realizada uma revisão bibliográfica sobre o princípio da igualdade e suas diferentes acepções, sobre as ações afirmativas e sobre a condição do negro no Brasil. Na segunda parte, uma exposição das leis do estado do Rio de Janeiro foi feita, para em seguida apresentar uma análise dos julgados pesquisados. Ao final, concluiuse que o argumento racial aparece mais nos julgados do que o social, mas que, ao longo dos anos, esse argumento desaparece gradualmente das decisões, deslocando o eixo da discussão para o critério social da carência. Ademais, concluiu-se que as ações afirmativas são meios legítimos de concretizar o princípio da igualdade, que distinguem-se de medidas universalistas, e devem com elas ser conjugadas.

Palavras-chave: Igualdade. Ações afirmativas. Cotas. Negros. Decisões judiciais. 


\begin{abstract}
This work aimed to study the principle of equality and affirmative action. The specific objective was to investigate whether in the Rio de Janeiro Court's decisions between 2001 and 2008 the racial argument was used more often than the social argument. The study was limited to the State of Rio de Janeiro, as it pioneered the implementation of quotas in public universities by a State law. The time delimitation is justified by the fact that the first State law came into effect in 2001 and 2008 was the last year of data collection from the Court's website. The work is divided into two parts: the first one consists of a literature review of the principle of equality and its various meanings, the affirmative action concept, and the condition of black people in Brazil. The second part discusses the relevant laws in the State of Rio de Janeiro, followed by an analysis of the decisions encountered during the referred period. This research concludes that the racial argument appears more frequently than the social argument; but over the years, this very argument faded away, shifting the centre of the debate to the criterion of social deprivation. Moreover, it concludes that affirmative action is a legitimate means of achieving the principle of equality, serving a different purpose than universal measures, and should be combined with them.
\end{abstract}

Keywords: Equality. Affirmative Action. Quotas. Black People. Judgments. 
$\underline{\text { Sumário }}$

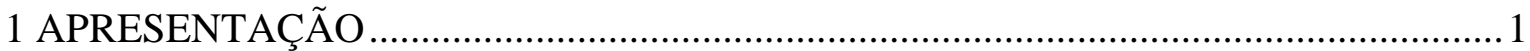

2 JUSTIFICATIVA DA ESCOLHA E DA IMPORTÂNCIA DO TEMA

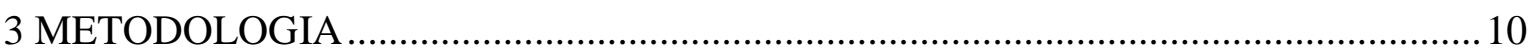

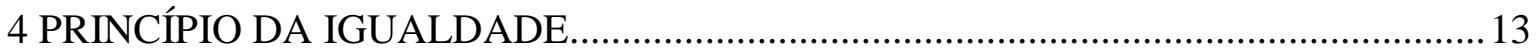

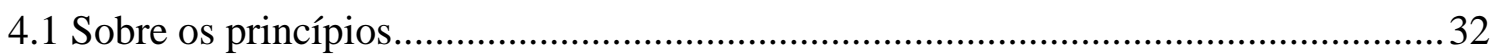

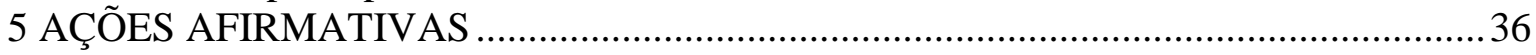

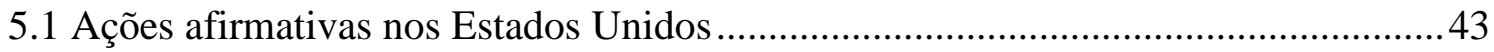

5.2 Ações afirmativas nas universidades no Brasil........................................................ 48

5.3 Principais argumentos contrários e favoráveis às ações afirmativas nas universidades

5.3.1 O ingresso na universidade deve ter como critério exclusivo o mérito................55

5.3.2 A qualidade do ensino universitário ficará prejudicada por um baixo desempenho dos alunos admitidos por meio de ações afirmativas ..............................57

5.3.4 A ausência de alunos negros nas universidades tem como causa a deterioração do ensino público médio e fundamental, de modo que a prioridade deveria ser a melhoria desses níveis escolares. A desigualdade é de ordem social, e não racial, pois no Brasil existe uma democracia racial. Portanto, a solução viria de uma política voltada para a população pobre.

5.3.5 Não existem raças e, por isso, não há sentido em políticas direcionadas a raças

5.3.6 Não há como definir quem é negro no Brasil. As ações afirmativas podem promover o oportunismo de pessoas que não correspondem aos povos ou grupos discriminados, pois há aqueles que nunca se identificaram como negros e assumem essa identidade étnica para serem beneficiados.

5.3.7 Cotas e ações afirmativas vão permitir que se forme uma elite negra. A grande massa negra e pobre continuará excluída.....

5.3.8 As ações afirmativas são inconstitucionais, pois contrariam o princípio de que todos são iguais perante a lei....

5.3.9 As ações afirmativas para negros em universidades seriam humilhantes para os negros.

6 O NEGRO NO BRASIL: O QUE OS NÚMEROS REVELAM...................................69

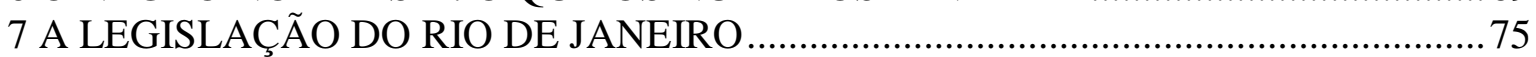

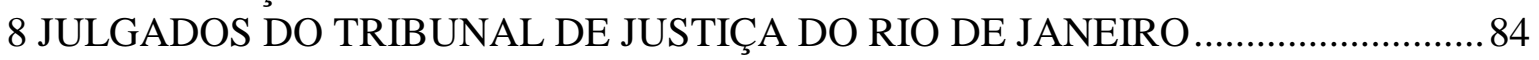

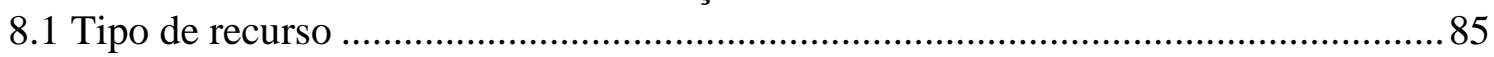

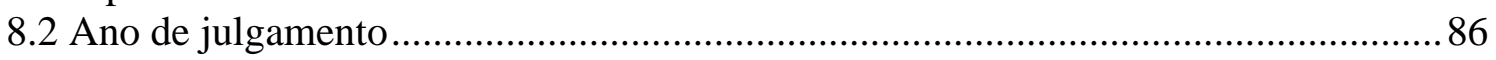

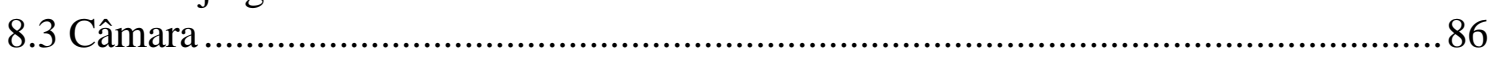

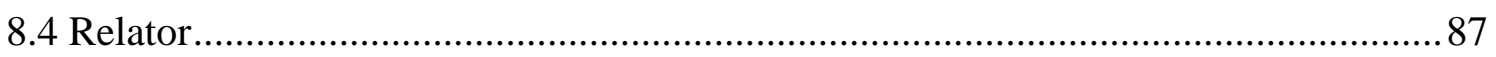

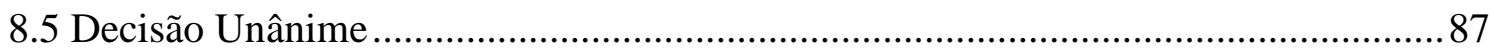

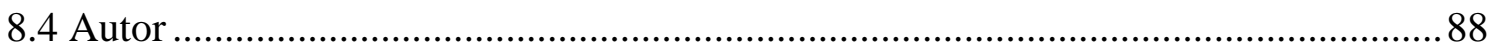

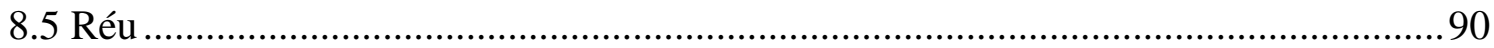

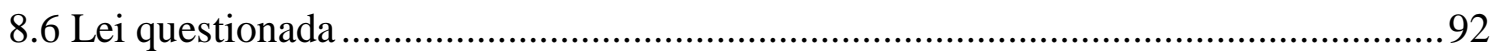

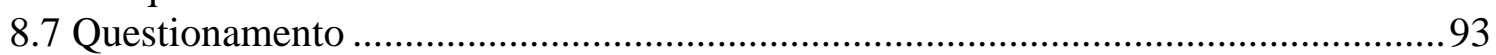

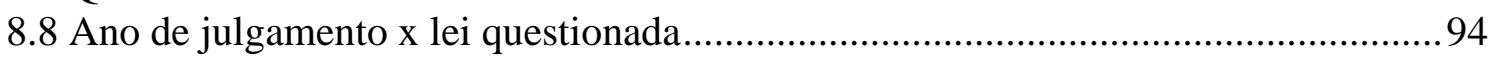

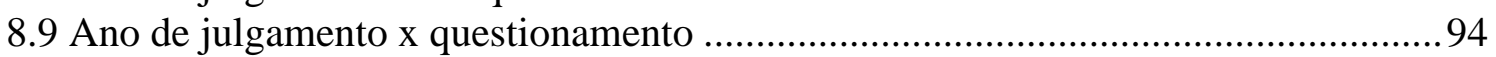

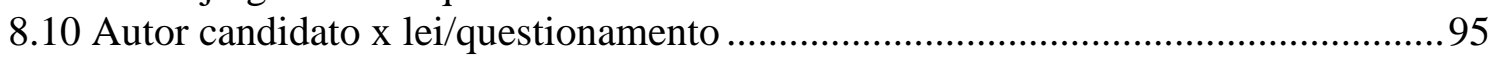

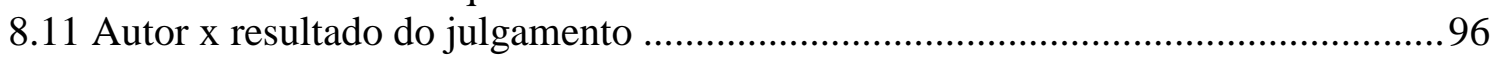

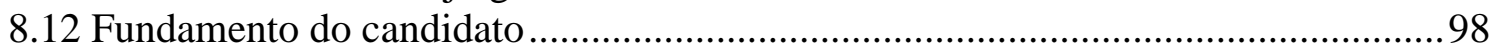




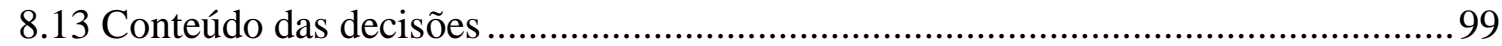

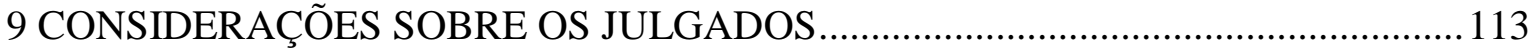

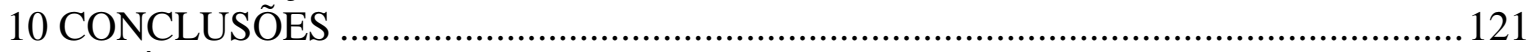

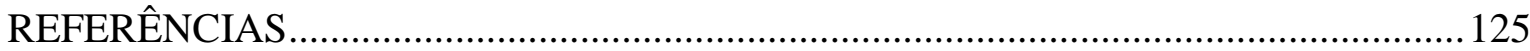




\section{APRESENTAÇÃO}

Todos os animais são iguais mas alguns animais são mais iguais do que os outros. A célebre frase de George Orwell (1982, p. 130) traduz a realidade de que, em tese, todos são iguais, mas na prática uns têm mais privilégios ou gozam de mais direitos que outros. A frase espelha a realidade desigual e injusta em que vivemos. Mas a partir dela podemos chegar a uma outra ideia: sim, os seres humanos são todos iguais, por simplesmente possuírem a condição da humanidade, mas, por razões históricas, culturais, econômicas etc. encontram-se em situações desiguais, injustamente diferentes. Para remediar a injusta realidade, os membros de um grupo que possuem ou gozam de menos direitos são considerados iguais entre si, mas desiguais em relação aos demais grupos, para que assim, sujeitos e destinatários de medidas e políticas distintas, possa-se alcançar uma igualdade de fato, uma igualdade real entre todos os grupos, naquilo que é essencial a todo o ser humano. A presente dissertação trata dessas medidas e políticas distintas.

O tema escolhido para esta pesquisa foi, mais precisamente, as ações afirmativas para negros nas universidades públicas brasileiras. Dentro desse tema, a curiosidade específica que motivou o estudo foi conhecer as decisões proferidas pelo Poder Judiciário do estado do Rio de Janeiro com relação ao uso, ao fundamento e à legalidade de medidas positivas que conferem aos negros uma posição diferente dos demais grupos de pessoas, no que tange o acesso às universidades públicas.

Ao longo da pesquisa, pretendeu-se responder à seguinte pergunta:

A existência de discriminação racial é um argumento mais utilizado que a existência de desigualdade social nas decisões do Tribunal de Justiça do Rio de Janeiro que trataram de cotas nas universidades estaduais do Rio de Janeiro, entre o período que vai de 2001 a 2008? Em que medida? ${ }^{1}$ Em outras palavras: quais são os argumentos utilizados pelos magistrados a julgarem os casos nos quais é questionada a adoção de ações afirmativas nas universidades públicas?

\footnotetext{
${ }^{1}$ A explicação para o recorte de pesquisa (Tribunal de Justiça do Estado de Rio de Janeiro e período temporal) será feita no capítulo sobre metodologia.
} 
Em virtude de ter existido mais de uma lei ${ }^{2}$ que regulamentou o sistema de reserva de vagas nas universidades públicas do estado do Rio de Janeiro, no período que vai de 2001 a 2008, a pergunta geral foi subdividida em três perguntas específicas, quais sejam:

1) Tendo em vista que a Lei $3524 / 2000$ reserva $50 \%$ das vagas para alunos que "tenham cursado integralmente os ensinos fundamental e médio em instituições da rede pública dos Municípios e/ou do Estado”, não há que se falar em raça, somente em origem escolar. Por essa razão, os julgados que de alguma forma questionam somente essa lei terão um olhar analítico particular, sendo que se pretende investigar aqui quais os tipos de argumentos mais utilizados para legitimar ou não o uso da ação afirmativa. Vale ressaltar que o intuito não é aprofundar-se na discussão sobre a legitimidade da ação afirmativa para alunos oriundos de escola pública, mas sim captar os argumentos utilizados nessa discussão, no que tange à legitimidade do uso da ação afirmativa, com vistas a comparar esses argumentos com aqueles utilizados na discussão sobre a legitimidade do uso desse tipo de política para o ingresso de negros nas universidades públicas.

2) A Lei 3708/2001 reserva $40 \%$ das vagas para alunos negros, sem revogar a Lei 3254/2000. Dessa maneira, temos que há cota para alunos da rede pública e há cota para alunos negros, sendo essas cotas independentes. A Lei 3708 apenas prevê que o número de alunos oriundos da rede pública e que são negros, e entrarem pela cota da Lei 3524 , será descontado da cota prevista na Lei $3708^{3}$. Estando, portanto, as duas leis em vigor à época e existindo duas formas de cotas, a curiosidade que surge é se a raça ou a origem escolar é o argumento mais mencionado nos julgados, e de que forma.

3) Por sua vez, a Lei 4151/2003 reserva $45 \%$ das vagas para alunos carentes, sendo que este percentual está distribuído da seguinte maneira: $20 \%$ para alunos da rede pública, 20\% para negros e 5\% para pessoas com deficiência, minorias étnicas, filhos de policiais civis e militares, bombeiros militares e inspetores de segurança e administração penitenciária, mortos ou incapacitados em razão do serviço. O

\footnotetext{
${ }^{2}$ Essas leis são a Lei 3524/2000, a Lei 3708/2001, a Lei 4151/2003 e a Lei 5074/2007. O conteúdo delas será explicado em capítulo específico, mais adiante.

${ }^{3}$ Por exemplo: a primeira lei reserva $50 \%$ das vagas para alunos da rede pública. Se, num caso concreto, há 100 vagas, 50 dessas são reservadas. Digamos que dos 50 alunos que estudaram na rede pública e que entraram pelas cotas, 20 sejam negros. A segunda lei reserva $40 \%$ das vagas para alunos negros. Assim, das 100 vagas, 40 são reservadas para negros. Se pela primeira lei já entraram 20 alunos negros, para completar a cota de $40 \%$ previsa na segunda lei será preciso apenas de mais 20 alunos negros.
} 
objetivo na análise dos julgados que mencionam essa lei é verificar se a raça ou a origem escolar é mais mencionada, e de que forma, ou se é apenas mencionado o requisito da carência, sem que as partes ou os desembargadores tenham entrado na questão da subcota de origem escolar ou da raça.

A Lei 5074/2007 veio apenas a alterar o inciso III e o $\S 3^{\circ}$ do art. $1^{\circ}$ da Lei 4151/2003. A entrada em vigor dessa lei, no entanto, não altera a essência do que se pretende investigar com a análise de julgados proposta nesta dissertação, e, por essa razão, a norma de 2007 não foi incluída na análise.

Como hipótese de resposta à pergunta geral, tem-se que os magistrados reconhecem a legitimidade do uso da ação afirmativa, mas somente para candidatos oriundos da rede pública de ensino, reconhecendo, portanto, somente a desigualdade de ordem social. Nesse aspecto, para os magistrados, preponderaria na ação afirmativa uma medida de redistribuição ${ }^{4}$.

As hipóteses de resposta às perguntas específicas são as seguintes:

1) O uso das ações afirmativas para o ingresso de alunos oriundos da escola pública é legítimo, porém deve-se investir na educação de base (no ensino fundamental e médio) para que os alunos que estudaram na rede pública tenham condições de passar no vestibular sem a necessidade de reserva de vagas.

2) No período em que a Lei $3524 / 2000$ e a Lei 3708/2001 estiveram ambas em vigor, houve mais ações judiciais de candidatos que não passaram no vestibular questionando a violação do princípio da igualdade pelo uso de raça como forma de reserva de vagas. Ou seja, a Lei 3708 foi mais questionada do que a Lei 3524. Outra hipótese, que não exclui a primeira, é a existência de julgados que trataram da discussão sobre a desproporcionalidade da reserva de $40 \%$ das vagas para alunos negros.

3) A hipótese é que a maioria dos julgados que se debruçaram sobre a Lei 4151/2003 concentrou-se mais na discussão do requisito da carência e menos na discussão das subcotas (raça e origem escolar).

\footnotetext{
${ }^{4}$ Em item próprio será explicada a dupla dimensão de justiça proposta por Nancy Fraser, mas cabe adiantar aqui que ela engloba medidas de redistribuição de riquezas materiais e medidas de reconhecimento, no sentido de que todas as pessoas e todos os grupos devem possuir paridade de participação na vida social (2003; 2007).
} 
Para a análise dos julgados coletados, o repertório teórico teve como base o estudo do princípio da igualdade, seu conceito e suas aplicações (capítulo 4), e sobre as ações afirmativas, seu conceito e suas aplicações (capítulo 5).

Um levantamento da legislação pertinente ao tema foi imprescindível: a Constituição Federal do Brasil, a Convenção Internacional sobre a Eliminação de Todas as Formas de Discriminação Racial, a Declaração Universal dos Direitos Humanos e as leis do estado do Rio de Janeiro que instituíram cotas para o acesso às universidades públicas desse estado.

Também foram coletados números de centros de pesquisa, como o Instituto Brasileiro de Geografia e Estatística (IBGE), o Instituto de Pesquisa Econômica Aplicada (Ipea) e o Datafolha, que revelam qual é a situação atual do negro no Brasil. O conhecimento desses dados, apresentados no capítulo 6, é importante pois, somente com a comprovação de que ainda existe uma situação de desigualdade injusta entre negros e não negros no país é que se pode justificar a adoção de um tratamento desigual para aquele grupo de pessoas. 


\section{JUSTIFICATIVA DA ESCOLHA E DA IMPORTÂNCIA DO TEMA}

Conforme é examinado em capítulo específico (6), os números oficiais falam por si só: há desigualdade socioeconômica entre negros (incluindo aqui os denominados pretos e pardos) e brancos no Brasil. Quanto a esse fato, não há discussão, pois até mesmo aqueles que criticam o uso de ações afirmativas reconhecem a desigualdade exposta pelos dados oficiais. Os números oficiais revelam, por exemplo, que a renda média do negro é menor do que a renda média do branco.

Entretanto, um dos argumentos usados pelas pessoas contrárias a políticas de ações afirmativas para negros é que, na verdade, esses números tratam de uma desigualdade social dissociada de qualquer fator racial ${ }^{5}$. Ou seja, os críticos reconhecem que a maioria dos negros é pobre, mas creditam esse fato à existência da escravidão no Brasil. Em outras palavras, os negros são, em sua maioria, pobres, muito provavelmente porque no passado existiu escravidão e eles sofrem até hoje as conseqüências sociais desse período de exploração.

Mesmo tomando como hipótese a premissa de que a discriminação racial $^{6}$ existiu somente no passado e hoje temos um problema apenas de desigualdade social, a conclusão a que se chega é que não foi suficiente proibir o racismo, proibir a discriminação e proibir a escravidão para melhorar a situação do negro. A história do Brasil prova que não bastam leis para proibir determinadas ações injustas, porque cento e vinte anos após a abolição da escravatura os números oficiais ainda nos mostram que os negros continuam em situação vulnerável: são os mais pobres, ganham menos, têm menor acesso à educação, à saúde etc.

Segundo Jaccoud:

\footnotetext{
${ }^{5}$ Sem se alongar na discussão, toma-se como premissa para esta dissertação a ideia já hoje bastante aceita (GUIMARÃES, 2002, LAFER, 2005, TELLES, 2003) de que raça é uma construção social, sem qualquer base biológica. Edward Telles cita W. I. Thomas, para quem "Se os homens definem situações como reais, elas se tornam reais em suas consequências" (TELLES, 2003, p. 39). Assim, independente de raça corresponder a qualquer característica biológica, o fato é que os seres humanos ainda usam desse conceito e o aplicam socialmente, de modo que sofrem das suas consequências.

${ }^{6}$ É importante fazer uma distinção conceitual no início deste trabalho. Há discriminação quando uma pessoa é impedida de exercer algum direito ou de usufruir de oportunidades em função da sua raça, sexo, idade, origem ou outra característica. Discriminação é, assim, uma ação ou omissão. Já o preconceito está situado no pensamento, na esfera subjetiva, e corresponde a preconcepções ou prejulgamentos não exteriorizados em forma de ação ou omissão que consiga impedir alguém de exercer seu direito. Por isso, o preconceito não é punível. Por fim, o racismo reflete uma ideologia em que determinados grupos ("raças") são natural e essencialmente superiores a outros.
} 
... não há dúvidas de que uma parte importante dos fatores que impedem a melhoria das condições de vida e oportunidades dos negros se encontra ofertada em padrões limitados e insuficientes devido à naturalização social da condição subalterna dessa população. (2008b, p. 55)

E, não só. Pesquisas recentes mostram que a sociedade brasileira ainda se considera racista. Ainda é possível encontrar depoimentos de casos de preconceito e discriminação racial. Nancy Fraser relata o caso de um executivo, de terno e gravata, que é negro e não consegue um táxi em Nova Iorque, quando outras pessoas conseguem (2007, p. 116). No Brasil há diversos casos similares ${ }^{7}$, de pessoas negras e não pobres e que são discriminadas, colocando em xeque a premissa de que existe, hoje, uma desigualdade somente de ordem social. O fato é que, como bem lembra Walter Feinberg, uma política de erradicação da pobreza só terá sucesso a partir do momento em que as pessoas deixarem de ser pobres. No entanto, essa política tem um alcance limitado, pois uma pessoa negra que deixa de ser pobre não deixará de ser negra, mesmo depois de uma mudança de status educacional e econômico (1998, p. 45).

Teun A. Van Dijk lembra que o próprio interesse acadêmico no estudo do racismo surgiu tarde na América Latina, muito em razão da crença na democracia racial; do fato de as elites acreditarem que o racismo aqui era mais benevolente do que, por exemplo, nos Estados Unidos, onde ele foi mais explícito; de sempre ter-se atribuído à desigualdade social diferenças de classe social e não de raça $(2008$, p. 13). O autor também afirma que o estudo do racismo nunca fez parte da corrente predominante da pesquisa acadêmica, e de alguma forma aqueles que se debruçavam sobre esse estudo eram (e são) vistos como militantes, como políticos, e não como responsáveis pela construção de um "empreendimento científico relevante" (2008, p. 14).

No início dos anos 50, conforme relata Hasenbalg (2007, p. 234), a Unesco passou a financiar algumas pesquisas sobre as questões raciais no país, com a intenção de explicar ao mundo a "convivência harmoniosa" da democracia racial brasileira.. Essa expectativa não se confirmou, pois foram constatadas associações claras entre a cor da pele, ou a raça, e a pobreza, principalmente nos estudos feitos em São Paulo. Foi a primeira vez que a pesquisa acadêmica nacional passou a discutir o mito da democracia racial.

Ronaldo Jorge A. Vieira Júnior lembra que no meio jurídico a discussão sobre o racismo era praticamente inexistente, durante a primeira metade do século passado, visto

\footnotetext{
${ }^{7}$ Há um caso amplamente comentado à época, e que inclusive foi matéria da Revista Veja de 7 de julho de 1993 (p. 66-67): a filha (negra) de um ex-governador do Espírito Santo foi verbal e fisicamente agredida por uma empresária e seu filho dentro do elevador do prédio onde moravam, sendo chamada de "empregadinha".
} 
que predominava a crença na democracia racial. Assim, não se falava em discriminação, em danos, tampouco em reparação. Somente na segunda metade do século XX, a discussão assumiu outros enfoques: já se falava em discriminação, porém aquela ocorrida entre particulares, e o estudo jurídico sobre o racismo acontecia primordialmente no âmbito do direito penal (2005, p. 82-83).

Hoje, a discussão da questão racial assume cada vez mais um caráter público. Além do reconhecimento da discriminação entre particulares, há agora uma discussão sobre o racismo que ocorre na esfera social e coletiva, dentro das instituições e até mesmo no inconsciente coletivo. O Estado, assim, tornou-se responsável pela desigualdade entre negros e brancos, no passado e no presente, e possui o dever de implementar medidas que diminuam essa desigualdade no decorrer do tempo, até que ela finalmente deixe de existir.

A escolha de estudar as ações afirmativas na educação se deve a alguns fatores. Primeiramente, a política destinada ao acesso de negros nas universidades parece ser a mais polêmica: a impressão que se tem é que há pouco embate de ideias dedicado, por exemplo, às cotas para mulheres nos partidos políticos e às cotas para pessoas com deficiência no trabalho, mas há muito debate - em livros, artigos, matérias de jornal sobre as cotas para pessoas negras. Uma segunda razão para a escolha do tema diz respeito à importância da educação, sobre a qual é necessário dizer pouco: dentro dos padrões sociais ocidentais, uma pessoa formalmente educada tem mais chances de obter mais sucesso profissional, aumentar sua renda, desenvolver-se como pessoa em diversos aspectos, ter conhecimento sobre diferentes assuntos etc. Além disso, conforme constata Flávia Piovesan, a universidade é um espaço de poder, e é necessário democratizar o acesso ao poder (2005, p. 51). As ações afirmativas para pessoas negras são uma maneira de promover essa democratização.

Ademais, acredita-se que a discussão sobre justiça deva ser o centro das reflexões em uma faculdade de direto, pensamento corroborado por Calixto Salomão. O professor explica que, desde os antigos, passando pelos modernos, tentou-se chegar a concepções absolutas, transcendentais de justiça. Citando Amartya Sen (Uma ideia de justiça), Salomão argumenta que para nos aproximarmos mais do ideal de justiça precisamos lutar contra as injustiças (informação verbal, 2009a).

Atualmente, até já há um número razoável de livros, artigos, matérias sobre ações afirmativas. Essa produção intelectual é uma representação concreta do muito que já foi dito, escrito e debatido sobre ações afirmativas: conceitos, tipos, origem, importância, (in) constitucionalidade. Outro estudo sobre o tema, sob as mesmas perspectivas já antes 
abordadas, poderia levar a uma sensação de satisfação, pelo fato de que, mesmo assim, novas ideias seriam trazidas ao diálogo, ou ao menos determinados pontos seriam reforçados. De outro lado, porém, poderia levar a uma sensação de insatisfação, em razão de correr o risco de não provocar mudanças, ou seja, os olhares e opiniões sobre o tema não mudariam já que a discussão se apresenta sempre da mesma forma.

Não se tem a pretensão de, com a presente pesquisa, realmente transformar posicionamentos e influenciar as pessoas. Se isso for alcançado indiretamente, é algo sem dúvida positivo. O objetivo, no entanto, é apresentar o tema sob uma perspectiva diferente daquela mais costumeira ${ }^{8}$. A impressão que se tem é que aqueles que são favoráveis às ações afirmativas para negros nas universidades continuarão sendo, e aqueles que são contrários assim o continuarão. Talvez a partir da tentativa de apresentar esse outro olhar o olhar daqueles que possuem o poder de aplicar o direito na prática, em casos concretos alguma mudança no entendimento de toda essa discussão tenha mais chances de acontecer.

A escolha de analisar as decisões do Poder Judiciário decorre do entendimento de também ser imprescindível conhecer, após alguns anos de vigência da primeira lei que implementou uma medida de ação afirmativa em universidades, o que pensam os magistrados. Em outras palavras, como julgam aqueles que possuem o poder de aplicar uma norma a um caso concreto e, fazendo isso, decidir não somente um caso particular, mas influenciar a decisão de muitos outros e toda uma política pública pensada e executada pelo poder público. ${ }^{9}$

O estudo de casos do Tribunal de Justiça do Rio de Janeiro faz mais sentido para esta pesquisa, pois a existência de cotas naquele estado traz um rico material de análise sobre como a questão social e a questão racial se operam na prática.

Em resumo, parte-se da ideia de que descobrir e entender como os conceitos de igualdade material e ações afirmativas são aplicados de verdade, na realidade, pode ser mais útil e pode contribuir mais para todo o debate que cresce no Brasil. Pode contribuir

\footnotetext{
${ }^{8}$ O objetivo é, nas palavras de Jocélio dos Santos e Delcele Queiroz, transformar um discurso opinativo em um discurso analítico (2005-2006, p. 60).

${ }^{9}$ Não fará parte da discussão deste trabalho, mas a posição aqui defendida é que os magistrados possuem o papel de completar a criação do direito, e não apenas de reconstruir o que pensou o legislador, ou de ser apenas a "boca da lei” (MONTESQUIEU, 1973, p. 160). Nas palavras de Eros Grau: “... o intérprete autêntico 'produz' direito porque necessariamente completa o trabalho do legislador (ou do autor do texto, em funções regulamentar ou regimental). O intérprete autêntico completa o trabalho do autor do texto normativo; a finalização desse trabalho, pelo intérprete autêntico, é necessária em razão do próprio caráter da interpretação, que se expressa na produção de um novo texto sobre aquele primeiro texto" (2005, p. 60). Daí o tamanho poder dos magistrados na definição do conteúdo normativo e na sua aplicação aos casos concretos.
} 
com a própria comunidade científica e novos tipos de conhecimento produzidos. Pode, inclusive, apontar novas estratégias para os defensores das ações afirmativas. 


\section{METODOLOGIA}

Para saciar a curiosidade específica que motivou esta pesquisa, todas as decisões disponíveis na página eletrônica do Tribunal de Justiça do Rio de Janeiro ${ }^{10}$, do ano de 2001 ao ano de 2008, que trataram de cotas, ações afirmativas, negros e universidade, foram coletadas e analisadas, em sua íntegra (e não apenas pela ementa).

O estado do Rio de Janeiro foi escolhido porque é o único que possuiu e possui lei estadual para reservar vagas nas suas universidades públicas estaduais. Nas outras universidades onde há a adoção de ações afirmativas, a base normativa não foi uma lei, mas um ato da própria universidade, com fundamento na garantia constitucional da autonomia universitária ${ }^{11}$.

Além desse primeiro recorte espacial, também foi aplicado um temporal: as decisões buscadas foram todas de 2001 a 2008. O marco inicial se justifica em razão do primeiro ano de vigência da primeira lei estadual que instituiu o uso de cotas para pobres em universidades estaduais do Rio de Janeiro ${ }^{12}$, e o marco final corresponde ao segundo ano da elaboração da presente pesquisa, durante o qual foi feita a coleta dos julgados analisados no terceiro e último ano da elaboração desta dissertação ${ }^{13}$.

A página eletrônica do Tribunal de Justiça do Rio de Janeiro onde consta a pesquisa de jurisprudência contém oito campos ou filtros de busca de julgados. O procedimento metodológico de busca foi o seguinte: em tipo de consulta, o filtro escolhido foi "por assunto/palavra na ementa"; em origem foi escolhido "Tribunal de Justiça - processos cíveis"; em ano foram escolhidas as decisões julgadas a partir de 2001 até 2008; em desembargador não houve escolha, tampouco em órgão julgador; o campo ementário não foi selecionado; e, finalmente, no campo assunto foi digitada a expressão "cotas e universidades", a expressão "ações afirmativas e universidades", a expressão "negros e

\footnotetext{
${ }^{10}$ Ressalta-se que o Poder Judiciário do Rio de Janeiro não necessariamente apresenta uma visão de todo o Poder Judiciário no Brasil. O Estado do Rio de Janeiro foi pesquisado em razão do que se explica neste capítulo, e toda e qualquer afirmação que é feita nesta dissertação refere-se somente ao universo de julgados pesquisado.

${ }^{11} \mathrm{O}$ art. 207 da Constituição Federal prevê que "As universidades gozam de autonomia didático-científica, administrativa e de gestão financeira e patrimonial, e obedecerão ao princípio de indissociabilidade entre ensino, pesquisa e extensão."

${ }^{12}$ A primeira lei estadual foi a 3254/2000, a segunda foi a 3708/2001, a terceira a 4151/2003, com alteração da 5074/2007, todas revogadas, e a que está hoje em vigor é a lei 5346/2008. A primeira lei data de 28 de dezembro de 2000, e por essa razão o ano de 2001 é o marco inicial da pesquisa de julgados.

${ }^{13}$ Apenas para conhecimento, em 2009 estão disponíveis na página do Tribunal três novos julgados, sendo um deles a representação por inconstitucionalidade, mencionada nas páginas 77, 78 e 79 desta dissertação.
} 
universidades", a expressão "negros e cotas e universidades" e a expressão "negros e ações afirmativas e universidades”. Nesse campo, as aspas não foram digitadas, já que a intenção não foi obter julgados que contivessem esses termos nessa ordem exata, mas apenas decisões que contivessem necessariamente os termos escritos em ordem aleatória, próximos ou distantes no texto.

Até a data final para a coleta de julgados (24 de dezembro de 2008), foram encontrados cento e um casos para a primeira expressão, dezesseis para a segunda, trinta e oito para a terceira, trinta para a quarta e dez para a quinta, totalizando cento e noventa e cinco. Desconsiderando dois que tratavam de assuntos diferentes ${ }^{14}$ e os que apareceram em mais de um termo de busca, o número total de casos distintos analisados foi cento e oito.

É importante ter em mente que nem sempre o Tribunal disponibiliza todos os julgados em sua base de dados eletrônica online ${ }^{15}$, no entanto não foi encontrada nenhuma informação a esse respeito na página eletrônica acessada. Caso o Tribunal de Justiça do Rio de Janeiro não disponibilize todas as decisões julgadas, ou seja, caso o banco de dados online não esteja completo, não há como saber se as decisões encontradas por meio da pesquisa feita no âmbito desta dissertação correspondem a $100 \%$ das decisões proferidas de 2001 a 2008 ou se correspondem a uma amostra. Na conclusão da presente pesquisa, portanto, jamais se poderá falar em "tendência do Tribunal de Justiça do Rio de Janeiro", ou em "jurisprudência dominante”, uma vez que só se pode ter certeza da tendência real de um Tribunal quando o universo com o qual se está trabalhando é conhecido. Dessa forma, o universo de julgados desta pesquisa corresponde simplesmente ao número total de decisões encontradas no banco de dados online.

Como repertório teórico para esta análise, foram estudados diversos autores, dos clássicos (Aristóteles, Rousseau etc.), passando pelos modernos (Rawls, Dworkin, Bobbio) até aqueles que têm despontado no estudo sobre direitos humanos (Sarmento e outros). Além disso, uma atenção especial foi dedicada a livros e artigos que tratam especificamente das ações afirmativas, seu histórico, seu conceito, suas espécies.

Visto que para a aplicação de ações afirmativas é requisito um estado concreto de situações desiguais entre iguais, ou situações iguais entre desiguais, foi imprescindível a contextualização da situação do negro e do branco no Brasil. Para tanto, os dados mais

\footnotetext{
${ }^{14}$ A apelação 2240005 trata de leilão de bens da UERJ e a apelação 200700152219 trata de ação revisional de alimentos.

15 A premissa adotada é que não se está diante de uma amostra, a partir da qual seria possível fazer inferências para o todo, justamente por não se conhecer o universo total e a porcentagem a que a eventual amostra corresponderia.
} 
recentes, sobre o negro brasileiro, de órgãos de pesquisa oficiais, como o IBGE (Instituto Brasileiro de Geografia e Estatística) e o Ipea (Instituto de Pesquisa Econômica Aplicada), foram consultados. Não é objeto desta dissertação a discussão sobre o conceito de negro no Brasil, de modo que se adotou a ideia de que negro corresponde aos pretos e aos pardos, padrão adotado pelo IBGE.

Como repertório normativo, foram utilizados a Constituição da República Federativa do Brasil, tratados internacionais pertinentes ao tema da igualdade, da discriminação racial e das ações afirmativas, e as leis do estado do Rio de Janeiro referentes à implementação de ações afirmativas nas universidades desse estado. 


\section{PRINCÍPIO DA IGUALDADE}

A concepção de igualdade $^{16}$ foi pela primeira vez concretizada, em termos jurídicos, nas declarações do século XVIII. Foi com as declarações ${ }^{17}$ francesa e americana, de 1789 e 1776 respectivamente, que pela primeira vez se falou em uma lei igualmente válida para todos os homens, ou igualdade de tratamento perante a lei ${ }^{18}$. Essa foi a consequência direta de uma luta contra um sistema de privilégios por nascença, que vigorava em um regime absolutista e aristocrático. Pela primeira vez, com a Declaração dos Direitos dos Homens, o próprio ser humano seria a fonte da lei, e não um deus ou os costumes da história (ARENDT, 1989, p. 324). Sob o conceito de igualdade formal, os seres humanos eram considerados de uma forma abstrata e geral, de modo que a lei deveria regular as situações da vida de igual maneira, independentemente de quais eram essas situações. A noção de igualdade formal tem, então, uma enorme importância histórica por ter constituído um freio aos privilégios legais.

Para Hannah Arendt, a Declaração de 1789 também se destinou a ser uma proteção necessária em uma era em que os indivíduos já não estavam a salvo nos estados onde

\footnotetext{
${ }^{16}$ Para Aristóteles, "a justiça nas transações entre um homem e outro é, efetivamente uma espécie de igualdade, e a injustiça uma espécie de desigualdade (...) Portanto, a justiça corretiva será o intermediário entre a perda e o ganho (...) O igual é intermediário entre a linha maior e a menor de acordo com uma proporção aritmética. (...) Ora, o juiz restabelece a igualdade. É como se houvesse uma linha dividida em partes desiguais e ele retirasse a diferença pela qual o segmento maior excede a metade para acrescentá-la ao menor. E quando o todo foi igualmente dividido, os litigantes dizem que receberam 'o que lhes pertence' isto é, receberam o que é igual (...) Logo, o justo é o intermediário entre uma espécie de ganho e uma espécie de perda..." (1973, p. 326-327). Bonavides faz um resumo da evolução das concepções de igualdade. Inicia lembrando que para Platão e Aristóteles haveria uma desigualdade natural entre os seres humanos, e que Hobbes fez estremecer essas premissas platônicas e aristotélicas, pois, para ele, haveria, ao contrário, uma igualdade natural no estado de natureza, o que causaria um estado de insegurança entre os homens. Justamente para criar um ambiente de paz e segurança é que os homens firmaram um contrato social, criando, então, uma desigualdade institucional. Os filósofos ainda precisaram traçar um caminho entre a igualdade natural e a igualdade civil. Rousseau chega, então, à igualdade perante a lei (2003, p. 211).

${ }^{17}$ Uma das fontes de inspiração das revoluções foi o filósofo inglês John Locke, conhecido por seu Segundo Tratado sobre o Governo, no qual defende que os homens nascem iguais e escolhem viver em sociedade. Para ele, o homem nasce em um estado de liberdade e de igualdade, "no qual é recíproco qualquer poder e jurisdição, ninguém tendo mais do que qualquer outro; nada havendo de mais evidente que criaturas da mesma espécie e da mesma ordem, nascidas promiscuamente a todas as mesmas vantagens da natureza e ao uso das mesmas faculdades, terão também de ser iguais umas às outras sem subordinação ou sujeição; a menos que o senhor de todas elas, mediante qualquer declaração manifesta de sua vontade, colocasse uma acima de outra, conferindo-lhe, por indicação evidente e clara, direito indubitável ao domínio e à soberania" (1973, p. 41).

${ }^{18}$ Bonavides (2003, p. 212) lembra que os dois princípios da igualdade - natural e civil - são, finalmente, exteriorizados na Constituição francesa de 1791, que incorporou o art. 111 da Declaração dos Direitos do Homem e do Cidadão: Os homens nascem e permanecem livres e iguais em direitos. As distinções sociais somente podem fundar-se na utilidade comum. É claro, contudo, que essa utilidade comum é relativa e histórica, e os seres humanos souberam preencher esse conceito das mais variadas formas...
} 
haviam nascido. Assim, a ideia da existência de direitos naturais, que emanavam da própria condição humana, era muito importante para que os indivíduos possuíssem direitos em quaisquer lugares. "Como se afirmava que os Direitos do Homem eram inalienáveis, irredutíveis e indeduzíveis de outros direitos ou leis, não se invocava nenhuma autoridade para estabelecê-los; o próprio Homem seria a sua origem e seu objetivo último" (ARENDT, 1989, p. 324). A autora completa sua tese refletindo sobre o paradoxo da Declaração, que reconhecia a existência de direitos de um ser humano, porém que não existia, era abstrato (1989, p. 325).

No século XIX, com o crescimento das massas de trabalhadores e desempregados, a luta pelos direitos sociais e econômicos ganhou força, de modo que a concepção de igualdade formal começou a ser superada pela ideia de igualdade material ou substancial. À luz desse novo entendimento, o ser humano passou a ser considerado em sua forma concreta, com suas particularidades e peculiaridades. Por conseguinte, a lei não poderia ser igual para todos quando as pessoas viviam sob condições diversas, sob pena de se perpetuar uma situação de desigualdade. A lei deveria, assim, tratar os iguais de maneira igual e os desiguais de maneira desigual, na medida dessa desigualdade. Só desse modo seria possível buscar a igualdade de fato entre todos. E só desse modo seria possível a garantia dos direitos humanos, com o respeito à dignidade de todas as pessoas humanas.

Robert Alexy defende que o princípio da igualdade não pode querer dizer que todas as pessoas sejam iguais sob todos os aspectos, tampouco que o princípio consiga prever todas as diferenças e distinções entre as pessoas. Nesse sentido, é preciso haver um meiotermo entre os dois extremos, e assim o autor também chega à fórmula clássica: "Há de tratar igualmente o igual e desigualmente o desigual" (2007, p. 350-351) (tradução da autora $\left.^{19}\right)$.

De modo similar consagrou Rui Barbosa, em sua célebre Oração aos Moços, ao afirmar que as desigualdades podem e devem ser combatidas com a aplicação da clássica fórmula:

\begin{abstract}
A regra da igualdade não consiste senão em quinhoar desigualmente aos desiguais, na medida em que se desigualam. Nesta desigualdade social, proporcionada à desigualdade natural, é que se acha a verdadeira lei da igualdade. O mais são desvarios da inveja, do orgulho, ou da loucura. Tratar com desigualdade a iguais, ou a desiguais com igualdade, seria desigualdade flagrante, e não igualdade real. Os apetites humanos conceberam inverter a norma universal da criação, pretendendo, não dar a cada um, na razão do que vale, mas atribuir o mesmo a todos, como se todos se eqüivalessem.
\end{abstract}

\footnotetext{
${ }^{19}$ No original: "Hay que tratar igual a lo igual y desigual a lo desigual".
} 
(...)

Mas, se a sociedade não pode igualar os que a natureza criou desiguais, cada um, nos limites da sua energia moral, pode reagir sobre as desigualdades nativas, pela educação, atividade e perseverança. Tal a missão do trabalho. (1920)

No âmbito internacional, inspirada na Declaração Universal dos Direitos Humanos, de $1948^{20}$, foi aprovada a Convenção sobre a Eliminação de Todas as Formas de Discriminação Racial, adotada pelas Nações Unidas em 21 de dezembro de 1965. Esse documento concretizou em termos jurídicos o entendimento de que os seres humanos, para serem mais eficazmente protegidos, deveriam ser considerados em suas particularidades.

Segundo Flávia Piovesan e Luis Carlos Rocha Guimarães,

na qualidade de instrumento global de proteção dos direitos humanos ditado pelas Nações Unidas, a Convenção integra o denominado sistema especial de proteção dos direitos humanos. Ao contrário do sistema global de proteção que tem por destinatário toda e qualquer pessoa, abstrata e genericamente considerada, o sistema especial de proteção dos direitos humanos é endereçado a um sujeito de direito concreto, visto em sua especificidade e na concreticidade de suas diversas relações. Vale dizer, do sujeito de direito abstrato, genérico, destituído de cor, sexo, etnia, idade, classe social, dentre outros critérios, emerge o sujeito de direito concreto, historicamente situado, com especificidades e particularidades. Daí apontar-se não mais ao indivíduo genérica e abstratamente considerado, mas ao indivíduo especificado, considerando-se categorizações relativas ao gênero, idade, etnia, raça,... (2000, p. 355)

O artigo $1^{\circ}$ da Convenção define a discriminação racial como toda distinção, exclusão, restrição ou preferência que tenha por objeto ou resultado anular ou prejudicar o reconhecimento, gozo ou exercício dos direitos humanos e liberdades fundamentais em pé de igualdade.

O tratado das Nações Unidas veio transcender a ideia de que os Estados possuem apenas deveres de caráter negativo (não apoiar, ou proibir práticas de caráter discriminatório), para dar à luz a ideia de que os Estados também devem tomar medidas de caráter positivo, dentre elas, as ações afirmativas. Gomes afirma o que valia à época e aindo é válido hoje: “... a ideia de neutralidade estatal tem-se revelado um formidável fracasso... passaram-se os anos (e séculos) e a situação desses grupos marginalizados pouco ou quase nada mudou" (2001, p. 36).

De modo geral, as leis existiam somente para proibir condutas discriminatórias e racistas. O que se percebe é que nem sempre é suficiente a proibição legal da discriminação para que a igualdade seja alcançada ou que se resulte a inclusão de modo

\footnotetext{
${ }^{20}$ Seu art. I prevê que "Todos os seres humanos nascem livres e iguais em dignidade e direitos". Disponível na página http://www.onu-brasil.org.br/documentos_direitoshumanos.php. Acesso em: 30.12.2009.
} 
automático. Por vezes, aliada à vertente repressivo-punitiva, é necessária a vertente promocional, isto é, políticas positivas que acelerem o processo de igualdade e inclusão.

Walter Feinberg explica porque as leis antidiscriminatórias não são suficientes:

\begin{abstract}
No entanto, leis antidiscriminatórias não buscam aumentar o número de grupos previamente discriminados em um determinado espaço. Elas simplesmente visam tornar atos de exclusão baseados em fatores alheios, como raça, religião, etnicidade, gênero e assim por diante, ilegais. (1998, p. 4) (tradução da autora ${ }^{21}$ )
\end{abstract}

O parágrafo $4^{\circ}$ do art. $1^{\circ}$ da Convenção prevê a possibilidade de adoção de medidas especiais, assim conceituando as ações afirmativas:

\begin{abstract}
Não serão consideradas discriminação racial as medidas especiais tomadas com o único objetivo de assegurar o progresso adequado de certos grupos raciais ou étnicos ou de indivíduos que necessitem da proteção que possa ser necessária para proporcionar a tais grupos ou indivíduos igual gozo ou exercício de direitos humanos e liberdades fundamentais, contanto que tais medidas não conduzam, em consequência, à manutenção de direitos separados para diferentes grupos raciais e não prossigam após terem sido alcançados os seus objetivos.
\end{abstract}

No direito pátrio, o artigo $3^{\circ}$ da Constituição Federal estabelece, como um dos objetivos fundamentais da República Federativa do Brasil, a promoção do bem de todos, sem preconceitos de origem, raça, sexo, cor, idade e quaisquer outras formas de discriminação. Os verbos "construir", "garantir", "erradicar" e "promover”, presentes nos quatro incisos desse artigo, denotam um agir, simbolizando a mudança de uma visão estática de igualdade (negativa) para uma visão dinâmica e eficaz (positiva) (MELLO, 2000, p. 5). Ademais, o caput do artigo $5^{\circ}$ preceitua, claramente, a igualdade de todos perante a lei, sem distinção de qualquer natureza: “Todos são iguais perante a lei, sem distinção de qualquer natureza, garantindo-se aos brasileiros e aos estrangeiros residentes no País a inviolabilidade do direito à vida, à liberdade, à segurança e à propriedade... ".

O que fazer quando as pessoas já se encontram em situações desiguais? Interpretase a igualdade prevista no artigo $5^{\circ}$ em seu sentido material ou substancial. O texto constitucional traz outras previsões que têm, como fundamento, a igualdade material. Esse é o caso dos incisos XXX e XXXI do art. $7^{\circ}$, por meio dos quais se estabelecem, dentre os direitos dos trabalhadores, a proibição de diferença salarial por motivo de sexo, idade ou

\footnotetext{
${ }^{21}$ No original: However, nondiscrimination laws do not actively seek to increase the number of previously discriminated against people in a given area. They simply aim to make acts of exclusion that are based on extraneous factors, such as race, religion, ethnicity, gender, and so forth, illegal.
} 
estado civil, e a proibição de discriminação no tocante a salário e critérios de admissão da pessoa com deficiência. ${ }^{22}$

Dessa forma, caso as pessoas se encontrem em situações diversas, a lei para elas deverá incidir de uma forma também diversa, atendendo às peculiaridades da situação, com o intuito de reduzir essa desigualdade e promover a igualdade de fato.

Nesse sentido, já afirmou Boaventura dos Santos que "as pessoas e os grupos sociais têm o direito a ser iguais quando a diferença os inferioriza, e o direito a ser diferentes quando a igualdade os descaracteriza" (1997, p. 122). Na mesma linha, Nancy Fraser propõe que o reconhecimento deve ser universalista quando o não reconhecimento envolve a negação da humanidade de um grupo, mas deve ser específico quando se nega aquilo que é distintivo de um grupo (2007, p. 121).

José Afonso da Silva explica a corrente nominalista, para a qual os seres humanos nascem e vivem desiguais, e a corrente idealista, que postula nascerem os seres humanos iguais. Pertencentes a essa última corrente, o autor cita Locke e Montesquieu, para quem os seres humanos viviam em igualdade no estado de natureza, e também cita Rousseau, para quem, no entanto, haveria duas espécies de desigualdade:

\footnotetext{
Concebo, na espécie humana, dois tipos de desigualdade: uma, que chamo de natural ou física, por ser estabelecida pela natureza e que consiste na diferença das idades, da saúde, das forças do corpo e das qualidades do espírito e da alma; a outra, que se pode chamar de desigualdade moral ou política, porque depende de uma espécie de convenção e que é estabelecida ou, pelo menos, autorizada pelo consentimento dos homens. Esta consiste nos vários privilégios de que gozam alguns em prejuízo de outros, como o serem mais ricos, mais poderosos e homenageados do que estes, ou ainda por fazerem-se obedecer por eles. (ROUSSEAU, 1973, p. 241)
}

Hannah Arendt considera que a vida política baseia-se na ideia de que é possível construir a igualdade por meio da organização, pois o homem pode agir, mudar e construir o mundo comum com os seus iguais e somente com os seus iguais. Por esse motivo as comunidades insistiriam na homogeneidade étnica, para eliminar as distinções naturais que despertam um ódio silencioso, desconfiança e discriminação, "porque mostram com impertinente clareza aquelas esferas onde o homem não pode atuar e mudar à vontade, isto é, os limites do artifício humano" (1989, p. 335). A autora pondera que, para as

\footnotetext{
${ }^{22}$ Aliysson Mascaro lembra que mulheres não são iguais aos homens na sociedade, o consumidor não é igual ao fornecedor na sociedade e o negro não é igual ao branco na sociedade, e essa desigualdade deve ser refletida na legislação (informação verbal, 2009).
} 
comunidades, o "estranho", o diferente, assusta, pelo fato de fugir ao controle e à vontade dos homens. Explica:

\begin{abstract}
Se um negro numa comunidade branca é considerado nada mais do que um negro, perde, juntamente com o seu direito à igualdade, aquela liberdade de ação especificamente humana: todas as suas ações são agora explicadas como consequências 'necessárias' de certas qualidades do 'negro'. (1989, p. 335)
\end{abstract}

O filósofo John Rawls (2008), em sua teoria sobre a posição original, explica que homens e mulheres, com gostos, temperamentos e convicções comuns, porém temporariamente sem saber quais serão suas posições na sociedade, ao firmarem o contrato social, escolhem dois princípios fundamentais que regerão a vida em sociedade. A análise proposta pelo filósofo é que as pessoas vão escolher aqueles princípios que de alguma forma servirão a eles, independente da posição social que venham a $\operatorname{ocupar}^{23}$. Nessa situação hipotética inicial todos são iguais e possuem os mesmos direitos no processo de escolha das regras de organização da sociedade.

Os princípios que escolhem, então, sob o "véu da ignorância", são (i) aquele que garante a mais ampla liberdade política compatível com uma igual liberdade para todos algo como "a minha liberdade termina onde começa a do outro" - e (ii) aquele que determina que as desigualdades sociais e econômicas não devem existir a não ser na medida em que favoreçam o benefício absoluto dos membros em pior situação na sociedade (2008, p. 14-18).

O primeiro princípio claramente associa-se às liberdades clássicas, aos chamados "direitos humanos de primeira geração". Já o segundo princípio, conhecido como princípio da diferença, explica Rawls, quer dizer que

\footnotetext{
${ }^{23}$ Seguindo essa ideia, Walter Feinberg apresenta o seguinte exemplo: "suponha que ao invés de a escravidão ter acontecido com membros de um grupo racial específico, tenha acontecido de forma aleatória com os novos imigrantes. Suponha que potenciais imigrantes soubessem, antes de deixar seus países, que eles seriam designados para posições na nova terra e que muitos seriam arrancados de suas famílias, acorrentados juntos e amontoados em um navio onde muitos morreriam, e onde aqueles que sobrevivessem chegariam aqui como escravos sem qualquer controle sobre o bem-estar de seus filhos... é difícil imaginar que muitos imigrantes europeus que escolheram vir voluntariamente para a América ainda sim teriam escolhido vir" (1998, p. 5859) (tradução da autora). No original: "Suppose that instead of slavery being assigned to members of a specific racial group, it had been assigned on a random basis to all new immigrants. Suppose that potential immigrants knew, before leaving home, that they would be assigned to positions in the new land and that many would be wrenched from their families, chained together and crammed into ocean ships where many would die, and where those who lived would arrive here as slaves with no control over the well-being of their children ... it is hard to imagine that many European immigrants who chose voluntarily to come to America would still have taken the chance to do so".
} 
As desigualdades sociais e econômicas... só serão justas se resultarem em vantagens recompensadoras para todos, e, em especial, para os membros menos favorecidos da sociedade. Esses princípios excluem a justificativa das instituições com base na argumentação de que as privações de alguns são compensadas por um bem maior agregado. Pode ser conveniente, mas não é justo que alguns tenham menos para que outros possam prosperar. Porém não há injustiça nos benefícios maiores recebidos por uns poucos, contanto que, com isso, melhore a situação das pessoas não tão afortunadas. (2008, p. 18)

Se ao finalmente firmar o contrato social, alguém percebe, então, que se encontra em uma situação de desvantagem (de diversas ordens) em relação aos demais, é justo, a partir do segundo princípio, que a pessoa em pior situação seja favorecida. O intuito por trás desse princípio é que a igualdade seja atingida, ou, ao menos, que o resultado final seja o mais próximo de uma situação ideal de igualdade.

Para o autor, há bens primários - como direitos, liberdades, oportunidades, renda, riqueza e autorrespeito - aos quais todos devem ter igual acesso, para que, então, possam exercer sua liberdade e realizar seus desejos. Sem essa igualdade de disposição dos bens primários, não é possível que cada um exerça sua liberdade de modo pleno (2008, p. 7677).

Quanto a isso, na verdade, Rawls reconhece que na sociedade há possuidores de talentos e os mais afortunados, e há aqueles em posições piores. Para buscar ao máximo a igualdade, o filósofo americano propõe a aplicação do princípio da diferença e da reparação quando se trata do que ele chama de desigualdades imerecidas (de berço e de talentos naturais, por exemplo):

\begin{abstract}
Assim, o princípio postula que, para tratar a todos com igualdade, oferecer genuína igualdade de oportunidades, a sociedade deve dar mais atenção aos possuidores de menos dotes inatos e aos oriundos de posições sociais menos favoráveis. A ideia é reparar o viés das contingências na direção da igualdade. (2008, p. 120)
\end{abstract}

Para concretizar essa proposta, Rawls explica que

Os naturalmente favorecidos não devem beneficiar-se apenas por serem mais talentosos, mas somente para cobrir os custos de educação e treinamento dos menos favorecidos e para que usem seus talentos de maneira que também ajudem os menos favorecidos. Ninguém merece sua maior capacidade natural nem um ponto de partida mais favorável na sociedade. (2008, p. 121)

Complementa essa ideia com um exemplo, que, apesar de falar em pessoas menos inteligentes, não deixa de ser uma referência às pessoas menos afortunadas, que nasceram em contrariedade aos padrões institucionalizados: "Na aplicação desse princípio, talvez se 
viessem a despender mais recursos com a educação dos menos inteligentes, e não dos mais inteligentes, pelo menos durante certo período da vida, digamos os primeiros anos de escola”. (2008, p. 120). O investimento alocado por certo tempo justifica-se para que os “menos inteligentes" alcancem, de forma mais rápida, a posição dos "mais inteligentes". É difícil não referir esse trecho ao conceito de ação afirmativa, que nada mais é - muito em linhas gerais - do que uma medida temporária, focada em determinado grupo (sem dúvida não os menos inteligentes, mas aqueles que estão excluídos dos padrões sociais), para que este grupo alcance mais rapidamente uma situação melhor.

Rawls continua esse raciocínio afirmando que a educação não deve ser aferida puramente sob aspectos de eficiência econômica ou bem-estar social, mas deve ser considerada quando ela consegue capacitar uma pessoa para que desfrute da cultura e participe das atividades da sociedade, e "proporcionar a cada indivíduo um sentido seguro de seu próprio valor" (2008, p. 121). Esse papel da educação pode ser associado às ideias de redistribuição de riquezas (eficiência econômica e bem-estar social) e de reconhecimento (sentido seguro de seu próprio valor), que serão mais bem explicadas nas próximas páginas.

Sobre a teoria de John Rawls, Ronald Dworkin faz uma consideração interessante e original a seu respeito. Dworkin explica que o direito de todos à igualdade de respeito não é fruto do contrato social, mas, ao contrário, precede a esse contrato: para que todos os seres humanos possam arbitrar sobre as regras do contrato em pé de igualdade, eles já devem possuir um direito à igualdade de consideração e respeito; é uma condição para a admissão à posição original. Por ser um pressusposto, a igualdade é um direito fundamental (2002, p. 280).

\footnotetext{
Logo, podemos dizer que a justiça enquanto eqüidade tem por base o pressuposto de um direito natural de todos os homens e as mulheres à igualdade de consideração e respeito, um direito que possuem não em virtude de seu nascimento, seus méritos, suas características ou excelências, mas simplesmente enquanto seres humanos capazes de elaborar projetos e fazer justiça. (DWORKIN, 2002, p. 281)
}

Ikawa, ao considerar a teoria de Rawls, propõe algo diferente: o ser humano deve ser considerado como já tendo nascido ocupando uma posição social relativa à raça, à classe econômica e ao gênero: 
dignidade) e como diferente em uma série de fatores sociais, de gênero, de raça. Percebe-se, nesse sentido, uma imparcialidade tingida pelo princípio da isonomia, que reconhece diferenças relevantes, e trata igualmente os iguais e desigualmente os desiguais. Ainda, percebe-se uma imparcialidade marcada pela consideração de diferenças construídas moralmente como relevantes por uma história, por hierarquias morais convencionais não necessariamente condizentes com o princípio de igualdade de respeito. A percepção dessas diferenças permitirá a reversão de processos distributivos econômicos e de reconhecimento inferiorizantes. (2008, p. 66)

Assim, a autora entende que o ser humano não pode ser considerado em sua forma abstrata, ou como se todos tivessem contratado sob um véu da ignorância princípios que valeriam em qualquer situação em que as pessoas viessem a se encontrar, como propõe Rawls, mas sim que seja considerado em sua forma concreta. Somente dessa maneira poderão fazer sentido princípios que considerem desigualmente as pessoas que se encontram em situações desiguais, em razão dos valores dominantes de uma determinada sociedade em um determinado contexto histórico.

Para o italiano Norberto Bobbio, só é possível pensar em igualdade quando fazemos as duas seguintes perguntas: igualdade entre quem e igualdade em quê? (2002, p. 12). Isso, pois a noção de qualquer valor é histórica e mutável, assim como são os direitos humanos $^{24}$. Não existe um conceito absoluto e perene de igualdade. Existem, sim, diversos conceitos, assim como enfoques, localizados no tempo e no espaço.

Dworkin, por exemplo, ressalta que não há um único conceito de igualdade previsto na Décima Quarta Emenda da Declaração de Direitos dos Estados Unidos, mas que o conteúdo desse conceito deve ser preenchido de tempos em tempos (2002, p. 348). Alexy entende que o conteúdo do mandado de igualdade deve ser material, e não formal, no sentido de que por trás dos juízos de igualdade há sempre uma relação "triádica": " $a$ é igual a $b$ com respeito à propriedade $P$ " (tradução da autora ${ }^{25}$ ). $\mathrm{O}$ autor classifica essa proposição como juízos de igualdade parcial, pois não se está comparando todas as características de $a$ com as de $b$, mas somente parte delas (2007, p. 352).

Após diversas conquistas históricas, pode-se entender que, ao menos e talvez no mundo ocidental, todos os seres humanos são essencialmente iguais, pelo simples fato de pertencerem à humanidade. Todos os seres humanos seriam iguais em sua dignidade. Assim, a primeira pergunta de Bobbio estaria respondida. A questão, no entanto, ainda reside na segunda indagação, pois é certo que os seres humanos não são, não podem e não

\footnotetext{
${ }^{24}$ Apesar de serem históricos e mutáveis, os direitos humanos nunca devem regredir, mas sim terem seu rol expandido.

${ }^{25}$ No original: " $a$ es igual a $b$ con respecto a la propiedad $P$ " $(2007$, p. 352).
} 
devem ser iguais em tudo ${ }^{26}$, e, assim, pergunta-se em que eles deveriam ser iguais sob quaisquer hipóteses.

Segundo Nancy Fraser, os seres humanos devem ter a possibilidade de participar igualmente na vida social, e para isso devem ser reconhecidos pelos padrões culturais institucionalizados e ter recursos materiais ${ }^{27}$. Segue explicando que "quais pessoas precisam de qual (is) tipo (s) de reconhecimento em quais contextos depende da natureza dos obstáculos que elas encontram em relação à paridade participativa” (2007, p. 123).

Desse modo, a igualdade assume diversos significados a depender do contexto. Justamente porque existem diversas concepções é que Dworkin, por exemplo, defende que não se pense mais na igualdade em termos abstratos (igualdade de oportunidades, igualdade de resultado etc.), e que a sociedade dedique seu tempo a pensar em que as pessoas concretas precisam ser iguais e maneiras de como alcançar essa igualdade (2005, p. XI).

Para José Afonso da Silva, os seres humanos são iguais naquilo que a norma de uma determinada sociedade, em um determinado tempo, define em que eles devam ser iguais:

\footnotetext{
Este [o legislador] julga, assim, como "essenciais" ou "relevantes", certos aspectos ou características das pessoas, das circunstâncias ou das situações nas quais essas pessoas se encontram, e funda sobre esses aspectos ou elementos as categorias estabelecidas pelas normas jurídicas; por consequência, as pessoas que apresentam os aspectos "essenciais" previstos por essas normas são consideradas encontrar-se nas "situações idênticas", ainda que possam diferir por outros aspectos ignorados ou julgados irrelevantes pelo legislador; vale dizer que as pessoas ou situações são iguais ou desiguais de modo relativo, sob certos aspectos. (2000, p. 219)
}

Na mesma linha Frischeisen registra que, ao menos no campo jurídico, o conteúdo do direito à igualdade variará conforme uma realidade construída por meio de constituições, de legislações e de tratados internacionais. As normas positivadas nesses documentos refletiriam a estrutura social e o momento histórico determinados (2007, p. 4$5)$.

\footnotetext{
${ }^{26}$ Essa teoria é conhecida como Igualitarismo, pela qual todos os seres humanos são iguais em tudo, sob todos os aspectos. Para Alexy, a igualdade absoluta, ainda que fosse possível, não seria desejável: "a coincidência de todos, sob todos os pontos de vista, teria como consequência que todos iriam querer fazer o mesmo. Entretanto, se todos fazem o mesmo, só será possível conseguir um nível intelectual, cultural e econômico muito limitado" (tradução da autora). No original: "La coincidencia de todos, desde todos los puntos de vista, tendría como consecuencia que todos querrían hacer lo mismo. Sin embargo, si todos hacen lo mismo, sólo es posible lograr un nivel intelectual, cultural y económico muy limitado" (2007, p. 350).

${ }^{27}$ As condições para a paridade participativa serão explicadas em alguns parágrafos seguintes.
} 
Hannah Arendt vê a igualdade não só como fruto de um momento histórico, mas como uma criação dos homens:

\begin{abstract}
A igualdade, em contraste com tudo o que se relaciona com a mera existência, não nos é dada, mas resulta da organização humana, porquanto é orientada pelo princípio da justiça. Não nascemos iguais, tornamo-nos iguais como membros de um grupo por força da nossa decisão de nos garantirmos direitos reciprocamente iguais. $(1989$, p. 335)
\end{abstract}

Para a concepção ilustrada na nossa Constituição Federal, nas declarações e nos tratados internacionais, entende-se que todo ser humano deve ter acesso a todas e quaisquer condições necessárias para que sua personalidade possa ser desenvolvida em seu maior potencial. As cartas positivas resumem isso, de uma maneira geral, nos chamados direitos civis, políticos, econômicos, sociais e culturais ${ }^{28}$. Dessa forma, responde-se à segunda indagação de Norberto Bobbio: todos os seres humanos devem ter observados os direitos que hoje, em nossa concepção, entendemos como direitos humanos, pois são direitos mínimos, sem prejuízo de, ao longo dos anos, esse rol de direitos se alargar.

O gozo desses direitos, no entanto, pode se dar sob diferentes formas, pois os seres humanos não são iguais em tudo, e, por isso, devem ter suas diferenças respeitadas para que o gozo dos direitos seja plenamente efetivado. Quer-se dizer com isso que algumas diferenças entre os seres humanos são relevantes no momento de usufruir direitos: uma criança com uma determinada deficiência deve receber um tipo de educação diferente de uma criança sem essa deficiência, sendo essa diferença de tratamento uma discriminação não arbitrária e necessária para que o direito à educação seja plenamente efetivado para as duas crianças.

Outras diferenças não podem ser levadas em conta no momento do gozo dos direitos, e aqui se entra no objeto sob estudo: as pessoas negras, por possuírem a pele mais escura e alguns traços físicos diferentes de pessoas não negras, não podem receber um tipo diferente de tratamento, de direito ou de fato, em razão dessa característica, sob pena de constituir-se uma discriminação arbitrária.

\footnotetext{
${ }^{28}$ São as conhecidas duas primeiras dimensões ou gerações dos direitos humanos. Pode-se falar em uma terceira, quarta ou até mesmo quinta geração de direitos, o que reflete o entendimento de Hannah Arendt de que os direitos humanos não são um dado, mas sim historicamente construídos e decididos (1989, p. 335). Mas, para fins deste estudo, são suficientes as noções gerais dos direitos das duas primeiras gerações ou dimensões.
} 
Para Robert Alexy, "se não há nenhuma razão suficiente para permitir um tratamento desigual, então está ordenado um tratamento igual” (tradução da autora ${ }^{29}$ ), ao passo que "se não há nenhuma razão suficiente para permitir um trato igual, então está ordenado um tratamento desigual" (tradução da autora ${ }^{30}$ ). É possível dar às duas frases o mesmo peso e a mesma importância, já que sempre haverá situações dos dois tipos (tratamento igual e tratamento desigual). Alexy, no entanto, reflete sobre uma possível assimetria entre a primeira e a segunda, pois, para ele,

\begin{abstract}
... o princípio geral de igualdade pode ser interpretado no sentido de um princípio de igualdade que, prima facie, exige um tratamento igual e somente permite um tratamento desigual se puder ser justificado com razões contrapostas. (tradução da autora $^{31}$ )
\end{abstract}

É claro que a relevância ou irrelevância de uma determinada característica é estabelecida historicamente, de acordo com os valores tidos como importantes nessa ou naquela sociedade. Hoje, no Brasil e na comunidade internacional, entende-se que as diferenças físicas entre negros e brancos não são relevantes, e devem ser vistas como vemos um cabelo liso ou um cabelo encaracolado, uma mão com dedos compridos ou uma mão com dedos mais curtos.

Quando diferenças que deveriam ser irrelevantes acabam sendo levadas em consideração no momento do direito aos direitos, ou no momento do gozo dos direitos, o resultado é uma situação injusta de desigualdade.

Para Bobbio, "uma desigualdade torna-se um instrumento de igualdade pelo simples motivo de que corrige uma desigualdade anterior: a nova igualdade é o resultado da equiparação de duas desigualdades" (2002, p. 32). Ou seja, essa citação traduz a aplicação da igualdade em seu aspecto material, já explicada anteriormente. Diante de uma situação já injusta, medidas e políticas devem ser aplicadas de formas distintas para grupos distintos, a fim de que, ao final, os grupos possam ser considerados iguais.

No caso dos negros, a mera igualdade formal não basta para colocá-los em pé de igualdade com os brancos. Resume Rafael Guerreiro Osório, com eficaz simplicidade:

\footnotetext{
${ }^{29}$ No original: "Si no hay ninguna razón suficiente para permitir un trato desigual, entonces está ordenado un trato igual" (2007, p. 360).

${ }^{30}$ No original: "Si no hay ninguna razón suficiente para permitir un trato igual, entonces está ordenado un trato desigual" (2007, p. 361).

${ }^{31}$ No original: “... el principio general de igualdad puede ser interpretado en el sentido de un principio de igualdad que, prima facie, exige un trato igual y sólo permite un trato desigual si puede ser justificado con razones contrapuestas" (2007, p. 363).
} 


\begin{abstract}
No momento da abolição, foram suprimidas as barreiras formais que a escravidão oferecia à competição dos negros com os brancos pelas posições sociais. Mas quando os portões são abertos e se faculta aos negros o ingresso na corrida, os brancos já estão quilômetros adiante. Essa é a condição inicial. Para que os negros superem a desvantagem imposta por ela, é preciso que, a cada geração, percorram uma distância maior do que a percorrida pelos brancos. Se não conseguem fazê-lo, a desigualdade racial existente no momento da abertura dos portões persiste. (2008, p. 66)
\end{abstract}

Assim, os negros precisam correr mais rapidamente, por seus próprios meios, para alcançar os brancos - o que em regra é difícil pelo fato de as instituições e as condições a que os negros estão sujeitos não facilitarem essa corrida. Se a corrida acontece dessa forma desequilibrada, a igualdade de fato levará muito tempo para ser alcançada, e não é justo que os negros tenham que esperar mais tempo para finalmente terem seus direitos mais básicos respeitados.

Para acelerar esse processo, o Estado pode implementar medidas que de alguma forma diminuam a distância e aproximem os negros dos brancos. Essas medidas são as ações afirmativas, e sobre elas o capítulo 5 discorrerá.

A igualdade pode se dar de diferentes formas. Nancy Fraser acredita que o conceito de justiça pressupõe tanto medidas de reconhecimento quanto de redistribuição (2007, p. 103). Essas medidas também servem para alcançar uma igualdade de fato.

Fraser procura romper com o conceito padrão de reconhecimento, aquele que reconhece a identidade de um grupo (por exemplo, do grupo de pessoas negras porque elas possuem determinadas características que as unem). Segundo esse modelo padrão, o não reconhecimento significaria a anulação ou a "depreciação" da identidade de um grupo diretamente por outro dominante ou indiretamente por padrões institucionalizados na sociedade. Essa depreciação da identidade coletiva acabaria também por provocar danos à própria subjetividade de cada um dos membros da coletividade (2007, p. 106).

Podemos tomar a seguinte situação como exemplo desse fenômeno: quando o padrão reconhecido de beleza são as mulheres altas, magras, brancas e loiras, quando a maioria das bonecas seguem esse padrão de beleza (são altas, magras, brancas e loiras), todo o grupo de pessoas que foge a esse padrão acaba por ter depreciada, de alguma forma, a sua própria beleza. Esse é um dano que tem impacto na identidade da coletividade como um todo, visto que a característica comum a todo o grupo não é representada. Mas, além desse dano coletivo, cada membro do grupo também pode sofrer algum abalo em sua identidade porque não corresponde ao padrão de beleza imposto. É provável que as 
crianças que são negras não se reconheçam nas bonecas com que brincam (ou, pior, que queiram ser iguais às bonecas).

Do mesmo modo, para não fugir da lógica do exemplo dado, não é difícil concluir que as pessoas negras têm, em alguma medida, suas identidades coletiva e individuais depreciadas quando observam que a maioria dos papéis nas telenovelas brasileiras representados por atores negros é de empregadas domésticas ou criminosos ${ }^{32}$.

\begin{abstract}
A esteriotipia foi particularmente notada na associação do negro com criminalidade em jornais, literatura e cinema; no desempenho de funções socialmente desvalorizadas na televisão, literatura infanto-juvenil e livros didáticos; na exploração de estereótipos de "mulata", "sambista", "malandro" e "jogador de futebol" na literatura, publicidade impressa e televisiva, e no cinema. (SILVA; ROSEMBERG, 2008, p. 82)
\end{abstract}

Outro fato que ilustra bem os padrões institucionalizados são os band-aids "cor de pele" (cor de qual pele? ${ }^{33}$ ).

Fraser entende que com esse modelo de reconhecimento, que se associa à identidade de um grupo, corre-se o risco de aniquilar as características individuais. Às vezes, a generalização para construir a identidade coletiva pode simplificar demais a complexidade existente dentro do grupo. Além disso, a filósofa explica que o modelo "trata as culturas como profundamente definidas, separadas e não interativas, como se fosse óbvio onde termina uma e a outra começa" (2007, p. 107).

Para superar esse risco, Nancy Fraser propõe que a base do reconhecimento seja o status social de um grupo, e não a sua identidade coletiva. Nesse sentido, o não reconhecimento não significaria a depreciação da identidade coletiva de um grupo, mas sim a "subordinação social no sentido de ser privado de participar como um igual na vida social” (2007, p. 107). O fim dessa injustiça, consequentemente, seria a inexistência da subordinação social, com a mudança dos próprios padrões institucionalizados de valoração cultural, de modo que todos tivessem o mesmo status social, participando igualmente na vida social.

\footnotetext{
${ }^{32}$ Sobre esse assunto, recomenda-se consultar a obra de Joel Zito Araújo, "A Negação do Brasil e o negro na história da telenovela brasileira". É importante ressaltar que ao falar sobre os papéis de empregadas domésticas, não há nenhuma intenção de depreciar essa profissão. A crítica reside no fato de que os negros historicamente são os "criados" (senzala) dos "senhores" (casa grande) e essa relação parece não mudar, até mesmo na ficção. Com relação aos criminosos, a constante representação desse papel por atores negros pode criar a falsa associação de que somente os negros cometem crimes.

33 Afinal, por que não band-aid de diferentes cores, como ilustra a seguinte página eletrônica: http://www.likecool.com/Ebon-Aide_Bandages--Health--Body.html. Acesso em: 26.12.2009.
} 
No exemplo dado sobre as telenovelas, uma medida simples seria contratar atores negros para representar outros papéis que não só de empregadas domésticas e criminosos. Do mesmo modo, as empresas de brinquedo poderiam fabricar bonecas negras, e as empresas de band-aid poderiam fabricar band-aids nas diversas tonalidades de pele, sem que houvesse uma única "cor da pele".

A filósofa americana alerta para outro ponto positivo na associação do reconhecimento à paridade de participação social: essa proposta tende a valorizar a interação entre os grupos, e não arrisca segregá-los, como pode acontecer com o modelo de reconhecimento que se associa à identidade coletiva. $\mathrm{O}$ primeiro modelo proposto parece ter mais chances de responder aos críticos das ações afirmativas, quando estes alertam para a possibilidade de segregação de raças com a adoção de ações afirmativas.

Ali Kamel, diretor de jornalismo da Rede Globo, publicou um livro cujo título é "Não somos racistas", e nele o autor defende que as ações afirmativas poderiam criar uma segregação entre raças no Brasil: “... instituir políticas de preferência racial... é se arriscar a pôr o Brasil na rota de um pesadelo: a eclosão entre nós do ódio racial, coisa que, até aqui, não conhecíamos" (2006, p. 40). Se existe risco, o fato é que, como nos mostra a história de escravidão, como nos mostram os números (a serem apresentados em outro capítulo), a nação conheceu e ainda conhece, em alguma medida, ao menos o preconceito racial. Em todo o caso, o conceito proposto por Fraser parece ter mais chances de combater argumentos como o apresentado pelo jornalista, pelo fato de justamente ser claramente contrário a qualquer tipo de segregação.

A outra dimensão de justiça proposta por Fraser é a redistribuição. A partir dela, também se enfatiza a justiça como a paridade social, mas aqui os grupos ou os próprios indivíduos precisam não só ser reconhecidos pelos padrões culturais institucionalizados, como precisam também possuir meios e recursos materiais para participar da sociedade. $\mathrm{O}$ pressuposto é uma alocação mais igualitária de recursos e bens.

Uma distribuição mais justa dos bens materiais não é suficiente para se alcançar a justiça, pois nem sempre todas as questões de injustiça estão reduzidas a um problema de classe. Assumir isso é afirmar que todas as pessoas ricas não sofrem preconceito ou discriminação, por exemplo, e uma afirmação desse teor ignora discriminações das mulheres no trabalho (o que não possui qualquer relação direta com o fato de essas mulheres possuírem mais ou menos recursos materiais) ou discriminações contra homossexuais (novamente, o que não possui qualquer relação direta com o fato de os homossexuais possuírem recursos materiais). 
Ikawa exemplifica a eventual indivisibilidade das medidas de reconhecimento e de redistribuição:

\footnotetext{
Ilustrativamente, enquanto a realocação de recursos fungíveis como o dinheiro atende primordialmente a uma redistribuição econômica, a criação por lei de cotas para participação na mídia atende primordialmente a uma redistribuição de reconhecimento. (2008, p. 79).
}

Dworkin distingue o direito a igual tratamento (equal treatment) do direito a um tratamento como igual (treatment as equal). No primeiro caso, explica o autor, existe um "direito a uma igual distribuição de alguma oportunidade, recurso ou encargo" (2002, p. 349). No segundo caso, existe um direito "de ser tratado com o mesmo respeito e consideração que qualquer outra pessoa" (2002, p. 350). Parece, então, haver um paralelo da ideia de igual tratamento de Dworkin à ideia de redistribuição de Fraser, e de tratamento como igual à ideia de reconhecimento. $\mathrm{O}$ autor americano conclui que, no caso da educação superior, não existe um direito de igual tratamento, ou seja, um candidato não tem direito a uma vaga, que é algo escasso. Mas um candidato tem o direito a um tratamento como igual, e, nesse sentido, o direito de ter seus interesses examinados como os de quaisquer outras pessoas, quando a faculdade decidir se a raça será um critério a ser levado em consideração no processo de admissão, para que se atinjam determinados objetivos sociais (2002, p. 350).

Para José Reinaldo Lima Lopes, a distribuição é a partilha de algo que é comum, é aplicar a cada parte que compõe um sistema algo que pertence a todo o sistema (2006, p. 142). O bem que será comum poderá variar conforme a sociedade e o tempo. Para resumir a discussão, entende-se, para fins deste trabalho, que o bem comum mínimo são os direitos humanos reconhecidos nas constituições e nos tratados internacionais. Assim, a educação é parte do sistema e a ela todos devem ter acesso. O mesmo acontece com a saúde, a segurança pública, a cultura etc.

Segundo o mesmo autor, dar a cada um a sua parte no mal (ônus) ou no bem (benefícios) comum corresponde à justiça distributiva. Ela se distingue da justiça comutativa (trocar), retributiva (devolver) e corretiva (restaurar a um estado anterior). Para trocar, por exemplo, é preciso antes saber o que pertence a cada parte, processo que pressupõe a definição daquilo que deve ser comum (2006, p. 144-145).

Os defensores da aplicação de ações afirmativas somente para pessoas com pouca renda (exemplo: cotas sociais e não raciais) são aqueles que entendem que para se alcançar 
a justiça são suficientes medidas de redistribuição. Essa é uma visão sobre a injustiça no Brasil reduzida apenas a uma má-distribuição de riquezas, como se não existissem outros problemas relacionados aos padrões culturais e ao reconhecimento de grupos. Para haver justiça, não necessariamente basta que um estudante pobre e negro passe no vestibular para alcançar um status social e conseguir participar da sociedade. Às vezes, mesmo que seja rico ou que tenha uma profissão reconhecida como digna pelos padrões sociais e culturais institucionalizados, esse estudante será parado por um policial na rua, sem nenhum fundamento aparente, ou será o último a ser atendido por um garçom em um restaurante.

Para responder a essas questões, Nancy Fraser propõe que, para existir justiça, deve haver no mínimo a paridade de participação social. E para que haja essa paridade, ao menos duas condições são necessárias:

\footnotetext{
Primeiro, a distribuição dos recursos materiais deve dar-se de modo que assegure a independência e voz dos participantes ... a segunda condição requer que os padrões institucionalizados de valoração cultural expressem igual respeito a todos os participantes e assegurem igual oportunidade para alcançar estima social. (2007, p. 119)
}

Essa dupla dimensão de justiça proposta pode ser aplicada ao objetivo de justiça das ações afirmativas, se entendermos que esse tipo de medida positiva tem como meta o reconhecimento de grupos e a redistribuição de riquezas.

Defensores de cotas para pessoas com renda baixa parecem entender que a justiça se realiza preponderantemente com medidas de redistribuição, enquanto defensores de cotas para negros, por exemplo (independentemente de eles serem pobres ou ricos), parecem entender que a justiça se realiza preponderantemente com medidas de reconhecimento.

A legislação do estado do Rio de Janeiro propõe uma conciliação dessa dupla dimensão de justiça: os autodeclarados negros somente poderão concorrer às vagas reservadas se forem "carentes" (termo utilizado na legislação, cujo conceito deverá ser preenchido por norma das próprias universidades).

No Brasil há uma confusão, no sentido de mescla ou sobreposição, de pobres e negros e, por essa razão, a imagem do pobre costuma ser associada à imagem do negro. 
O fato de a maioria dos pobres ser negra traduz, hoje, uma situação de causa e consequência ao mesmo tempo. Por isso, não se pode resumir essa realidade simplesmente à existência de desigualdade social. Se a classe e a cor se confundem, elas também correspondem a situações que devem e merecem ser vistas separadamente, pois pedem soluções distintas, ainda que conjuntas. Sarmento aponta que "os negros no Brasil sofrem tanto a injustiça no campo da distribuição como no campo do reconhecimento, e que essas injustiças se reforçam reciprocamente, agravando uma à outra” (2006, p. 140).

Mário Theodoro expressa sua opinião a respeito da confusão entre desigualdade social e racial:

\begin{abstract}
Grande parte do embate de idéias sobre as políticas de promoção da igualdade racial ainda continua restrito ao tema da pobreza, caindo em uma armadilha que confunde interlocutores ao identificar na pobreza as causas das diferenças observadas entre brancos e negros nos mais diversos campos. É essa confusão que se destaca, sobretudo, no debate sobre as cotas nas universidades. Sem levar em conta que se trata de uma política de combate à discriminação racial e, em última análise ao preconceito e ao racismo, alguns discursos, muitas vezes de forma até bem intencionada, buscando um intangível consenso, advogam pelas chamadas cotas para pobres. Assim, mais uma vez, é negado o mecanismo da discriminação e recusado o tratamento preferencial aos negros. (2008, p. 173)
\end{abstract}

Nesta dissertação defende-se a ideia de que cotas raciais e sociais são válidas e legítimas, desde que se tenha em mente que cada uma delas possui um determinado objetivo. As cotas sociais possuem o condão de trazer aqueles alunos de menor renda ou da rede pública à universidade, sem se preocupar necessariamente com a reparação de uma injustiça histórica, ou com o reconhecimento de um determinado grupo. Já as cotas raciais possuem essa motivação do reconhecimento, além de outras, como a promoção da diversidade no corpo estudantil, a projeção de negros em um espaço primordialmente ocupado por brancos e a mudança no estereótipo da pessoa negra. Com relação ao estereótipo, Feinberg explica que

\footnotetext{
...o que pode começar como uma diferença cultural resulta em uma desigualdade econômica que, por sua vez, reinforça a desigualdade cultural e educacional. Se é esperado que as mulheres trabalhem em casa, educação não é uma prioridade, e sem uma forte educação, as mulheres terão poucas escolhas a não ser trabalhar em casa. (1998, p. 44) (tradução da autora ${ }^{34}$ )
}

\footnotetext{
${ }^{34}$ No original: ... what may begin as a cultural difference results in an economic inequality that in turn reinforces the cultural and educational inequality. If women are expected to work in the home, education need not be a high priority, and without a strong education, women have little choice but to work in the home.
} 
O mesmo autor complementa essa ideia de um círculo vicioso com outro exemplo: um treinador bem-intencionado pensa que preparar um atleta negro será um "desserviço" (em vão) porque o treinador do nível seguinte não escolherá esse atleta se existem outros que são brancos e também podem jogar. Se por acaso houver um treinador bemintencionado nesse segundo nível, ele não escolherá atletas negros porque afinal não há atletas negros que foram treinados pelo técnico do primeiro nível. Além disso, os fãs terão a percepção de que os negros não são "adequados" para jogar aquele esporte ou para posições de liderança. Feinberg conclui, ao final, que "uma cultura é criada e mantida assim como, ainda que ninguém tenha tido a intenção de discriminar, as práticas discriminatórias são criadas e mantidas" (1998, p. 51-52).

Para tentar resumir a ideia principal apresentada acima, propõe-se a análise da figura da justiça, representada por uma estátua com venda nos olhos, e com uma balança em uma mão e uma espada na outra mão. Enquanto a balança representa o equilíbrio entre fazer e aplicar a lei (não fazer justiça com as próprias mãos), e a espada a garantia do cumprimento da lei, a venda nos olhos significa que a justiça deve ser cega às situações das pessoas. A ideia é que não se distinga o rico do pobre, por exemplo, para que todos sejam tratados de maneira igual (e que, principalmente, o rico não tenha privilégios por ser rico). Essa concepção claramente relaciona-se com a igualdade formal, para a qual o ser humano é visto de modo abstrato, neutro.

Hoje, no entanto, com a evolução do conceito e da aplicação da igualdade em seu sentido material $^{35}$, não faz mais sentido que a justiça tenha uma venda em seus olhos, pois, desse modo, as pessoas em situações mais desfavorecidas ou vulneráveis não receberão a especial atenção que precisam para que uma igualdade de fato seja alcançada. Sejam diferenças naturais ou sociais, justas ou injustas, o fato é que a mulher é diferente do homem, a criança é diferente do adulto, o negro é diferente do branco, a pessoa com deficiência é diferente da pessoa sem deficiência. E essas diferenças devem ser consideradas pela justiça no momento de elaboração e aplicação das leis.

\footnotetext{
${ }^{35}$ A evolução acontece justamente porque, segundo Bittar, por trás do direito estão valores, e esses valores precisam ser afirmados e reafirmados historicamente (informação verbal, 2009).
} 


\title{
4.1 Sobre os princípios
}

Até agora, falou-se sobre as diferentes acepções do princípio da igualdade e sua importância na história dos seres humanos. Cabe, agora, uma breve retomada ${ }^{36}$ acerca dos $^{2}$ significados dos princípios em um ordenamento jurídico, para que se reforce a importância de termos o princípio da igualdade em nossa Carta constitucional.

José Afonso da Silva (2000, p. 95) lembra que há diversas concepções da palavra princípio, como, por exemplo, o início, o começo de alguma coisa ou algum processo. Quando lemos princípios fundamentais no texto da Constituição Federal, o significado de princípio não é esse, mas sim o de um "mandamento nuclear de um sistema", que é a definição usada por Celso Antonio Bandeira de Mello:

\begin{abstract}
Mandamento nuclear de um sistema, verdadeiro alicerce dele, disposição fundamental que se irradia sobre diferentes normas compondo-lhes o espírito e servindo de critério para sua exata compreensão e inteligência, exatamente por definir a lógica e a racionalidade do sistema normativo, no que lhe confere à tônica e lhe dá sentido harmônico. (BANDEIRA DE MELLO, 2007, p. 932-933)
\end{abstract}

José Afonso da Silva faz também uma referência à atual Ministra do Supremo Tribunal Federal, Carmen Lúcia Antunes Rocha, para quem

Igualdade constitucional é mais que uma expressão de Direito; é um modo justo de se viver em sociedade. Por isso é princípio posto como pilar de sustentação e estrela de direção interpretativa das normas jurídicas que compõem o sistema jurídico fundamental. (SILVA, 2000, p. 217)

Para delimitar o significado de princípio, é muito comum os autores o distinguirem das regras. Ronald Dworkin, ao apresentar alguns critérios de distinção entre regras e princípios, defende que as "regras são aplicáveis à maneira do tudo-ou-nada. Dados os fatos que a regra estipula, então ou a regra é válida, e neste caso a resposta que ela fornece deve ser aceita, ou não é válida, e neste caso em nada contribui para a decisão" (2002, p. 39).

Para o autor, essa primeira distinção entre regras e princípios é de natureza lógica, e dela segue uma segunda distinção: a distinção com relação à dimensão: "os princípios possuem uma dimensão que as regras não têm - a dimensão do peso ou importância"

\footnotetext{
${ }^{36}$ Não é objeto desta dissertação a discussão sobre princípios de uma forma geral. Essa breve retomada é necessária apenas para uma melhor contextualização jurídica do princípio da igualdade.
} 
(2002, p. 42). Dessa forma, quando nos defrontamos com um conflito de princípios em um caso concreto, temos que levar em consideração a força relativa de cada um deles. $\mathrm{O}$ princípio será mais ou menos importante, terá mais ou menos peso, a depender do caso em questão.

Assim, o julgamento de um princípio não pode ser feito abstratamente, mas somente em um caso concreto. Podemos ler uma determinada regra em um documento e concluir imediatamente que ela é inválida, pois vai de encontro a uma regra superior. No caso dos princípios, eles não serão válidos ou inválidos em si, mas serão avaliados em um determinado caso e em determinadas circunstâncias, para então concluir-se pela sua aplicação ou pelo seu afastamento do caso.

Uma terceira possível distinção entre regras e princípios diz respeito ao resultado da decisão. Segundo Dworkin, as regras levam a resultados determinados e particulares. Por outro lado, "os princípios não funcionam dessa maneira; eles inclinam a decisão em uma direção, embora de maneira não conclusiva. E sobrevivem intactos quando não prevalecem" (2002, p. 57).

Alexy lembra que a distinção entre regras e princípios não é nova, mas que até hoje existe polêmica e confusão. Para o autor, regra e princípio são espécies de norma, que seria o gênero, pelo simples fato de constituírem um dever-ser. Ele afirma que são muitos os critérios para distinguir esses dois tipos de normas, e o mais utilizado é o da generalidade: os princípios teriam um grau de generalidade mais alto do que as regras, que são mais fechadas, mais específicas (2007, p. 64-65). O autor é conhecido por entender os princípios como um mandado de otimização:

\footnotetext{
O ponto decisivo para a distinção entre regras e princípios é que os princípios são normas que ordenam que algo seja realizado na maior medida possível, dentro das possibilidades jurídicas e reais existentes... O âmbito das possibilidades jurídicas se determina pelos princípios e regras opostos. (2007, p. 67-68) (tradução da autora ${ }^{37}$ )
}

Alexy (2007, p. 68) e Dworkin (2002, p. 39) concordam que os princípios podem ser cumpridos em diferentes graus, enquanto as regras ou são inteiramente cumpridas, ou não são.

Para Alexy, o conflito de regra se resolve mediante a introdução de uma "cláusula de exceção" (a previsão na própria regra de uma situação excepcional que afastará a

\footnotetext{
${ }^{37}$ No original: El punto decisivo para la distinción entre reglas y principios es que los principios son normas que ordenan que algo sea realziado en la mayor medida posible, dentro de las posibilidades jurídicas y reales existentes ... El ámbito de las posibilidades jurídicas se determina por los principios y reglas opuestos.
} 
aplicabilidade daquela regra, por exemplo) ou mediante a declaração de uma das regras inválidas, com a sua consequente expulsão do ordenamento jurídico (e, para isso, há diversas regras, como a da lei posterior revogar a lei anterior, ou a lei especial revogar a lei geral etc.) (2007, p. 69).

Por outro lado, a colisão (e não conflito) de princípios deve ser solucionada de outra maneira. Não é necessário existir uma cláusula de exceção, tampouco se fala em afastar um dos princípios do ordenamento jurídico. A colisão de princípios ocorre quando dois princípios válidos não podem ser aplicados em um caso concreto ao mesmo tempo. A solução sempre dependerá do caso concreto:

\begin{abstract}
Sob certas circunstâncias, um dos princípios precede o outro. Sob outras circunstâncias, a pergunta sobre qual é o princípio que prevalece pode ser solucionada de maneira inversa. Isso é o que se quer dizer quando se afirma que nos casos concretos os princípios têm peso diferente e que prevalece o princípio com maior peso. (2007, p. 71) (tradução da autora ${ }^{38}$ )
\end{abstract}

Para Eros Grau, o direito não deve ser interpretado "em tiras", ou seja, uma lei nunca pode ser lida de forma isolada, desprendida do seu contexto jurídico. A interpretação de uma lei qualquer deve percorrer o caminho dessa lei até a Constituição, para que o sentido do todo seja captado e, somente então, se possa captar o sentido daquela lei específica (2005, p. 127). Grau cita Romano, para quem

\begin{abstract}
... a interpretação da lei é sempre interpretação não de uma lei ou de uma norma singular, mas de uma lei ou de uma norma considerada em relação à posição que ocupa no todo do ordenamento jurídico; o que significa que o que efetivamente se interpreta é esse ordenamento e, como consequência, o texto singular. (2005, p. 127)
\end{abstract}

Esse caminho interpretativo deve ser feito à luz dos princípios constitucionais. São justamente os princípios que possuem a função de dar a unidade ao sistema, de dar coesão ao todo normativo.

Nesse sentido, Ikawa cita Canotilho, para quem o "princípio da unidade constitucional tem como objetivo evitar contradições, harmonizar conflitos e buscar interpretações que produzam um sistema unitário" (CANOTILHO apud IKAWA, 2008, p. 161).

\footnotetext{
${ }^{38}$ No original:... bajo ciertas circunstancias, uno de los principios precede al otro. Bajo otras circunstancias, la pregunta acerca de cuál es el principio que prevalece puede ser solucionada de manera inversa. Esto es lo que se quiere decir cuando se afirma que en los casos concretos los principios tienen diferente peso y que prima el principio con mayor peso.
} 
Fabio K. Comparato concorda que os princípios são normas com alto grau de generalidade e as regras são normas com conteúdo normativo mais preciso e concreto, acrescentando que a função social destas é "interpretar e concretizar os princípios, à luz do ideário vigente, em cada época histórica, nas diferentes culturas ou civilizações" (2006, p. $510)$.

O autor explica essa ideia com o exemplo do princípio da igualdade, o qual serve com perfeição a esta dissertação. A aceitação oficial do princípio da igualdade só ocorreu com a Revolução Francesa, a partir da qual se fez necessário eliminar a divisão da sociedade em estamentos. O princípio, então, possuía o conteúdo de isonomia formal, ou seja, todos eram iguais perante a lei. Posteriormente, com novas conquistas históricas, novas ideologias, novos entendimentos, o mesmo princípio passou, aos poucos, a ser traduzido também em outras regras: o direito de igualmente fruir das condições materiais, o direito das mulheres de serem tratadas como os homens, o direito de os negros serem tratados como os brancos, e assim por diante (2006, p. 510).

Para concluir esta parte, o importante é ter em mente que, independente da teoria ou dos critérios de distinção entre regras e princípios adotados, o que vale para o presente estudo é o peso e a importância do princípio da igualdade, eternizado na nossa Constituição Federal. Apenas pela consciência das conquistas históricas e das diferentes concepções, passadas e atuais, da igualdade, podemos ter a certeza de que a palavra "igualdade" (ou iguais, como está escrito no caput do art. $5^{\circ}$ ) não aparece por qualquer pequena razão no texto constitucional, tampouco nos tratados internacionais. Pelo contrário, o princípio da igualdade positivado tem a função de influenciar, de servir de referência para todas as elaborações legislativas e para todas as interpretações e decisões judiciais - dentre elas, as leis que estabeleceram as cotas no Rio de Janeiro e as decisões do Tribunal de Justiça desse estado. O princípio, junto com outros princípios, forma a unidade do nosso sistema jurídico e deve, assim, formar também a nossa moral, a nossa cultura e os valores da nossa sociedade. 


\title{
5 AÇÕES AFIRMATIVAS
}

Para que a igualdade de fato ou de oportunidades seja real entre grupos que se encontram em situações injustamente distintas - situações definidas com base em diferenças que deveriam ser irrelevantes, mas na prática não são - uma das políticas hoje conhecidas e aplicadas é a política de ações afirmativas.

Joaquim Barbosa Gomes esclarece, com precisão, que:

\begin{abstract}
ações afirmativas podem ser definidas como um conjunto de políticas públicas e privadas de caráter compulsório, facultativo ou voluntário, concebidas com vistas ao combate à discriminação racial, de gênero, por deficiência física e de origem nacional, bem como para corrigir ou mitigar os efeitos presentes da discriminação praticada no passado, tendo por objetivo a concretização do ideal de efetiva igualdade de acesso a bens fundamentais como a educação e o emprego. (2003, p. 27)
\end{abstract}

São medidas de caráter urgente, dada a realidade de desigualdade aguda na qual um grupo de pessoas deixa de ter alguns de seus direitos mais elementares observados, de modo a comprometer a sua dignidade humana.

São explicitamente não universais, pois visam à promoção de direitos do grupo excluído para garantir, a médio e longo prazo, o acesso equânime às mesmas oportunidades.

São afirmativas, ou positivas, pois requerem uma ação, um agente, um fazer, uma intervenção. Não se limitam a simplesmente proibir ou criminalizar determinadas condutas, como fazem leis com tal conteúdo, que se restringem a oferecer à vítima uma indenização ou reparação. Diferentemente, as ações afirmativas têm o objetivo de promover a efetiva igualdade de oportunidades e condições entre todos os seres humanos, mitigando ou eliminando as discriminações e desigualdades presentes e futuras. Essas medidas positivas também têm o caráter pedagógico de modificar a cultura e mentalidades existentes e revelar à sociedade a necessidade de observância aos princípios de igualdade, de dignidade, de pluralismo e de diversidade. 
Se uma característica, em princípio irrelevante, é usada para discriminar num sentido negativo, as ações afirmativas visam a utilizar essa mesma característica para discriminar em um sentido positivo ${ }^{39}$.

Encarnación Fernandez acrescenta que:

as ações positivas tratam de superar os obstáculos de caráter não jurídico. Isso é, os impedimentos sociais, estruturais, institucionais. Perseguem a integração social dos coletivos discriminados, o estabelecimento de condições que assegurem a todas as pessoas oportunidades semelhantes para exercer os próprios direitos e as próprias aptidões e condições potenciais, assim como possibilidades semelhantes de promoção econômica e social. (2003, p. 95) (Tradução da autora $^{40}$ ).

Para Luciana Jaccoud, as ações afirmativas possuem ainda outro objetivo: o de "promover a maior diversidade social de grupos sub-representados em certos espaços sociais" (2008a, p. 137).

A autora cita Valter Silvério, que identifica nas ações afirmativas a justiça compensatória, a justiça reparativa e uma forma de ação preventiva (SILVÉRIO apud JACCOUD, 2008a, p. 137).

No que tange aos tipos de justiça, Ikawa (2008, p. 233) pondera que um dos argumentos contrários às ações afirmativas que passa pela ideia de que os indivíduos, hoje, não podem "pagar" por uma discriminação passada, guarda relação com a justiça compensatória. Nessa lógica, torna-se difícil aceitar a restrição de direitos de indivíduos pelo fato de eles pertencerem a um determinado grupo, sendo que esses indivíduos não

\footnotetext{
${ }^{39}$ É polêmico utilizar a mesma característica que foi causa de discriminação para reparar essa discriminação. Muitos (KAMEL, FRY, MAGGIE) alegam que usar a mesma característica pode perpetuar a discriminação que se quer combater. Nikkel questiona "Quando a característica moralmente irrelevante foi vista como sendo irrelevante, pode ela ser devidamente utilizada como uma consideração relevante na distribuição de reparações àqueles que sofreram injustiças?" (tradução da autora). No original: When the morally irrelevant characteristic has been seen to be irrelevant, can this characteristic then properly be used as a relevant consideration in the distribution of reparations to those who have suffered injustices? (2002, p. 3). O autor segue explicando que o pressuposto de que a característica que deu base à discriminação inicial é a mesma que será usada como fundamento para reparar aquela discriminação é errado. A característica não é a mesma. "Enquanto que a compensação na forma de oportunidades extras é estendida a um homem negro em razão da discriminação passada contra negros, o fundamento para essa consideração não é o fato de ele ser um homem negro, mas o fato de ele ter sido sujeito a um tratamento desigual em razão de ser um homem negro" (tradução da autora). No original: "For if compensation in the form of extra opportunities is extended to a black man on the basis of past discrimination against blacks, the basis for this compensation is not that he is a black man, but that he was previously subject to unfair treatment because he was black" (2002, p. 4).

${ }^{40}$ No original: "Las acciones positivas tratan de superar los obstáculos de carácter no jurídico. Esto es, los impedimentos sociales, estructurales, institucionales. Persiguen la integración social de los colectivos discriminados, el establecimiento de condiciones que aseguren a todas las personas oportunidades semejantes para ejercer los propios derechos y las propias aptitudes y condiciones potenciales, así como posibilidades semejantes de promoción económica e social".
} 
foram os responsáveis diretos pela discriminação tampouco dela se beneficiaram ${ }^{41}$. Para esse tipo de justiça, a lógica é inter partes, ou seja, se A que causa dano a B, será A que deverá compensar esse dano causado a B. Já na lógica da justiça distributiva, prossegue a autora

\begin{abstract}
A responsabilidade por essa distribuição de benefícios e prejuízos contrária ao princípio da dignidade deve ser assumida pelo grupo beneficiado, ainda que o tenha sido indireta ou inarticuladamente. Trata-se, nesse sentido, não apenas de uma responsabilidade pelos resultados, mas de uma responsabilidade coletiva derivada de uma história compartilhada, de uma construção compartilhada de uma estrutura hierárquica moral de base racial que inferioriza o negro; trata-se de uma responsabilidade coletiva que persiste seja essa estrutura compartilhada articulada ou não, consciente ou não; que persiste mesmo sem culpa. (2008, p. 235, 236)
\end{abstract}

Gomes também explica a presença das lógicas da justiça compensatória e da justiça reparativa por trás das ações afirmativas. Explica, inicialmente, a justiça compensatória:

\begin{abstract}
... ao adotarem os programas de preferência em prol de certos grupos sociais historicamente marginalizados, essas sociedades estariam promovendo, no presente, uma 'reparação' ou 'compensação' pela injustiça cometida no passado aos antepassados das pessoas pertencentes a esses grupos sociais. Tal reparação se justifica na medida em que o processo de marginalização social tem uma inegável inclinação perenizante. (2001, p. 62)
\end{abstract}

Complementa essa afirmação com a ideia de que a compensação ocorre a uma pessoa ou a um grupo por um dano que lhe foi causado por outro grupo no passado (2001, p. 62-63). A questão que fica, no entanto, é quanto à discriminação ter ocorrido somente no passado. Será? Podemos afirmar, por todo o exposto nesta dissertação, que a discriminação racial ainda é atual, e não somente passada, e por isso precisa ser reparada e eliminada. Ainda que essa discriminação tivesse ocorrido somente no passado, é fato que as pessoas e os grupos só estão onde estão hoje em razão da história, em razão do passado. Ou seja, se tomarmos por premissa que a reparação de danos não deve ter somente um caráter individualista e civilista, e sim que, ao menos em termos de direitos humanos, a responsabilidade será sempre social, de todos, a compensação também deve funcionar nessa lógica coletiva. Até mesmo porque quando a discriminação não ocorre somente inter partes, mas ela é institucional, e faz com que seus efeitos se reproduzam ao longo do

\footnotetext{
${ }^{41}$ Esse "benefício" é relativo. Falar que indivíduos hoje não foram os responsáveis diretos pela discriminação pode ser um argumento considerado, ainda que esses indivíduos façam parte de uma sociedade que possui instituições e hierarquias valorativas que discriminam. Indivíduos brancos podem não discriminar e podem não concordar com a discriminação, mas não é possível afirmar que eles não tenham se beneficiado da discriminação, pois isso seria negar anos de história, já que a sociedade atual foi construída com base em anos e anos de escravidão, e posteriormente (até hoje) em anos e anos de discriminação e desigualdades.
} 
tempo sem que haja necessariamente uma pessoa certa e identificável responsável, a lógica do combate a esses efeitos tem que ser outra. Quando não há necessariamente um infrator, um violador, um discriminador certo, mas a sociedade foi e continua construída de forma que certos grupos são excluídos, a medida reparadora não pode ter um caráter individual, mas sim coletivo.

Sobre a justiça distributiva, explica o autor que ela "diz respeito à necessidade de se promover a redistribuição equânime dos ônus, direitos, vantagens, riqueza e outros importantes 'bens' e 'benefícios' entre os membros da sociedade” e que ela facilita o acesso de determinado grupo a determinadas posições "às quais teria naturalmente acesso caso as condições sociais sob as quais vive fossem de efetiva justiça” (2001, p. 66).

Vieira Junior esclarece que para adotarmos a ideia de responsabilidade do Estado pelos danos causados à população negra, no sentido reparatório, é fundamental superar a lógica da reparação civilista, nos seguintes termos: a) a subjetividade, a partir do dolo ou da culpa do agente, deve ser substituída pela objetividade, a partir da ação ou omissão do Estado, do dano e do nexo causal; b) a natureza privada, decorrente da ação entre particulares, deve ser substituída pela natureza pública, pois o Estado teve parte nos danos causados aos negros; c) o caráter individualista deve ser substituído pelo caráter coletivo, pois a população negra como um todo sofreu e sofre as consequências da escravidão e da discriminação racial; d) a atuação negativa do Estado, baseada na proibição e na punição das condutas discriminatórias, deve ser complementada por uma atuação positiva, para promover a igualdade substantiva; e) o enfoque criminal deve ser substituído pelo enfoque civil, em que a reparação pelos danos independa do cometimento do crime de racismo (2005, p. 90).

Para esse autor, as ações afirmativas ainda têm o potencial de promover a igualdade substantiva, de mitigar as desigualdades de riqueza fundadas em bases sociais, de projetar positivamente a imagem dos negros, de reparar os danos causados pela escravidão e por eventuais sistemas segregacionistas posteriores (2005, p. 86).

Mônica Zegarra vê no fundamento das ações afirmativas uma obrigação ética. Para a autora, essas políticas dificilmente conseguirão "zerar" o passado ou mudar toda a estrutura social. Mas elas se sustentam, pois os setores (e não cada indivíduo) que se beneficiaram de alguma forma com a escravidão possuem a obrigação ética e moral de assumir a responsabilidade histórica por ter colocado os negros em uma situação de extrema desigualdade com relação aos brancos (2005, p. 346). A autora segue citando Herreño Hernández, para quem: 
As reparações expressam apenas uma exigência de justiça e não um desejo de vingança. Falar de reparações é (...) reconhecer que foi cometido um crime, uma injustiça e uma violação massiva dos direitos humanos e da dignidade humana, refletida no rapto de milhares de africanos, sua deportação e escravidão (apud ZEGARRA, 2005, p. 346).

Em sentido parecido, Feinberg conclui que a ação afirmativa "é justificada não somente porque procura corrigir qualquer distorção na igualdade de oportunidades, mas porque procura eliminar a passada e a presente discriminação" (1998, p. 40) (tradução da autora $^{42}$ ). Mas o autor também explica que, muitas vezes (principalmente no caso norteamericano), as ações afirmativas são fundamentadas nos benefícios trazidos pela diversidade, que corresponde a uma ideia de justiça e igualdade que não passa pelas injustiças históricas e pela noção de compensação (1998, p. 76).

Rita Segato resume os impactos na academia e na sociedade com a implementação das ações afirmativas em dez "eficácias": (i) pela eficácia reparadora, haverá o ressarcimento, ou a compensação, pelos atos lesivos cometidos contra os negros; (ii) pela eficácia corretiva, o futuro de uma sociedade que discriminou e discrimina será redirecionado, além de haver o estímulo à confiança nas instituições públicas; (iii) pela eficácia educativa imediata, poderão ser esperados efeitos de curto e médio prazo na educação de jovens negros; (iv) pela eficácia experimental, será possível reavaliar os resultados da intervenção periodicamente, de modo que sempre se poderá adaptá-la e melhorá-la; (v) pela eficácia pedagógica, uma sala de aula onde alunos de diversas origens convivem será mais apta ao aprendizado; (vi) pela eficácia educativa de espectro ampliado, os jovens negros poderão se sentir mais estimulados ao ver que adultos da sua cor são professores seus, os jovens demandarão um ensino de qualidade da escola e de seus professores, os professores se empenharão mais para melhorar a performance de seus alunos negros; (vii) pela eficácia política, a nação aceitará publicamente sua responsabilidade pela prática sistemática do racismo ao longo dos anos; (viii) pela eficácia formadora da cidadania, a sociedade perceberá que possui liberdade para ditar seus novos rumos, de inventar e experimentar novas formas de convivência; (ix) pela eficácia comunicativa, a introdução do signo negro modificará gradualmente a forma como olhamos e lemos a paisagem humana; e (x) pela eficácia propriamente transformadora, não

\footnotetext{
${ }^{42}$ No original: Thus race-and-gender-based affirmative action is justified on the grounds, not just that it seeks to correct any distortion in equal opportunity, but that it seeks to end the effects of past and continuing discrimination.
} 
bastará introduzir o signo negro nos cenários onde ele não circulava, mas será preciso fazer isso reflexivamente, deliberativamente (2005-2006, p. 83-86).

Sarmento resume e propõe que são quatro os fundamentos ${ }^{43}$ mais usados para justificar a adoção de políticas afirmativas: (i) pela justiça compensatória, entende-se que é justo que a sociedade de hoje compense os negros por todo um histórico de discriminações e por injustiças presentes; (ii) pela justiça distributiva, são necessárias medidas que visem distribuir melhor os bens socialmente relevantes, de modo a tornar as relações raciais mais equitativas; (iii) pelo pluralismo, entende-se que as experiências humanas ficam mais ricas com a pluralidade racial; e (iv) pelo fortalecimento da autoestima da população negra, quebram-se os estereótipos negativos dos negros (2006, p. 154-156).

Retornando a Gomes, ele esclarece que as políticas de ações afirmativas ainda possuem o objetivo de eliminar os efeitos danosos da discriminação que persistem com o tempo, caso existam somente leis que proíbam essa discriminação. Em suas palavras:

\footnotetext{
Como se vê, a ação afirmativa tem como objetivo não apenas coibir a discriminação do presente, mas sobretudo eliminar os 'lingering effetcs', ie, os efeitos persistentes (psicológicos, culturais e comportamentais) da discriminação do passado, que tendem a se perpetuar. (2001, p. 47)
}

Conclui-se, pelo exposto, que tanto a natureza quanto os objetivos das ações afirmativas diferem das políticas públicas universalistas. Estas são um dever permanente do Estado e têm o objetivo de atingir a todos, sem distinções. Com essas políticas universais pode-se querer reduzir a pobreza de um país, de uma forma geral, sem necessariamente atentar às diferenças de raça, gênero, origem etc.

Outra coisa são as ações afirmativas, que, pela sua própria definição, não impõem ao Estado um dever permanente de ação. Elas justamente existem porque as políticas universais, ao atingir toda uma população, não dão conta, sozinhas, de atentar para diferenças de grupo. Às vezes, com políticas universais, determinados grupos que, por diversas razões, precisam de uma atenção especial em função de características próprias, acabam não se beneficiando dessas políticas como outros grupos o fazem. Ou simplesmente não podem esperar o longo tempo necessário para que uma política universalista surta efeito com resultados perceptíveis e significativos.

Feinberg é claro ao defender que as ações afirmativas possuem limitações e não são um meio de acabar com a pobreza. Ainda que os grupos estigmatizados contenham uma

\footnotetext{
${ }^{43}$ Os termos fundamento e eficácia estão sendo usados sem precisão semântica, de modo que Segato também poderia falar em dez fundamentos e Sarmento em quatro eficácias.
} 
porcentagem alta de pessoas pobres, para resolver o problema da pobreza, é preciso mais do que ações afirmativas. Esses programas apenas "movem" alguns indivíduos acima da "linha"; eles não encurtam a linha criando mais "posições". Além disso, a redução da privação econômica não é um objetivo restrito aos grupos destinatários das ações afirmativas, mas é uma meta social ampla, que vai além da ação afirmativa (1998, p. 7475).

De acordo com Jaccoud,

... se políticas sociais universais são imprescindíveis para o combate às desigualdades raciais em um país com o histórico de racialização da pobreza, como é o caso do Brasil, nos últimos 20 anos elas foram, progressivamente, deixando de ser consideradas como os únicos instrumentos necessários a serem adotados face ao objetivo de redução das desigualdades raciais. (2008b, p. 58)

Segundo a mesma autora, no caso da população negra, as políticas públicas universais têm ampliado as oportunidades da população negra, mas não têm conseguido reduzir as desigualdades entre essa população e a branca. (2008b, p. 59). Ocorre que essas políticas enfrentam obstáculos enraizados nas instituições sociais: ainda que, por exemplo, todos tenham acesso à educação formal, o preconceito e a discriminação racial podem acontecer dentro das escolas, dentro das salas de aula ${ }^{44}$. Edward Telles defende que

\begin{abstract}
... a reforma educacional e outros programas universalistas devam incluir mecanismos que assegurem à população preta e parda benefícios, pelo menos, no mesmo grau de que a branca, pois, caso contrário, podem resultar em ainda maior desigualdade racial. De fato, nos últimos quarenta anos, foi exatamente o que ocorreu. Os brancos se beneficiaram de forma desproporcional do aumento de vagas para ingresso nas universidades, o que deu aos brancos recém-formados maior acesso à classe média e aumentou, ainda mais, a desigualdade racial. (2003, p. 275)
\end{abstract}

Uma das formas de mudar isso de forma rápida é promovendo a ascensão do negro a diversos espaços e posições sociais até então reservados aos brancos. A cota racial tem, dentre seus objetivos, impactar na "composição de um novo perfil da elite brasileira, que passará a ser marcada por uma maior diversidade e pluralidade” (THEODORO, 2008, p. 174). O mesmo autor ainda considera que as cotas nunca alcançarão os de fato mais pobres ou os mais excluídos, e elas nem podem almejar isso, pois os mais pobres sequer chegam a concluir o ensino médio. "As cotas vêm possibilitar o acesso àqueles que atingiram um

\footnotetext{
${ }^{44}$ Quantos livros didáticos trazem exemplos de famílias negras? Quantos livros de história apresentam uma perspectiva dos negros que vieram da África e dos negros brasileiros, e não a mesma perspectiva eurocêntrica de sempre?
} 
dado grau de educação formal, promovendo a aplicação das oportunidades para esse grupo social” (THEODORO, 2008, p. 174). Aqueles alunos que conseguiram concluir o ensino médio e provavelmente parariam aí para já ingressarem (se é que já não ingressaram) no mercado de trabalho têm mais chances de subir um degrau, de dar mais um passo, com a existência das cotas ou pelo menos de algum tipo de ação afirmativa.

Um estudo do Programa das Nações Unidas para o Desenvolvimento (PNUD), citado por Vieira Júnior (2005, p. 91), aponta que as ações afirmativas são necessárias e devem ser combinadas com políticas universais. O estudo indica que a desigualdade vertical (entre as pessoas) aumentou em oposição à desigualdade horizontal (entre os grupos), e que:

\footnotetext{
para reduzir as desigualdades individuais e construir sociedades verdadeiramente inclusivas e equitativas, são necessárias outras políticas como as políticas que promovem o desenvolvimento econômico equitativo. (...) E sem elas [as ações afirmativas] é provável que as desigualdades e as exclusões socioeconômicas de grupos fossem piores do que são hoje.
}

Em resumo, as ações afirmativas possuem o potencial de atingir grupos específicos mais rapidamente, e ao mesmo tempo de abrir espaço para medidas universalistas.

\subsection{Ações afirmativas nos Estados Unidos}

O termo "ação afirmativa" foi utilizado pela primeira vez em 1961 no governo Kennedy, nos $\mathrm{EUA}^{45}$, no qual o Presidente buscou mitigar principalmente as discriminações raciais no emprego e na educação e, posteriormente, discriminações sofridas por outros grupos vulneráveis. Uma das formas pelas quais o Presidente fez isso foi a Ordem Executiva n. $10925^{46}$, que estabeleceu um comitê para cuidar de

\footnotetext{
${ }^{45} \mathrm{O}$ termo foi usado pela primeira vez nos Estados Unidos, mas o conceito de ação afirmativa surgiu na Índia, após a Primeira Guerra Mundial, quando o jurista e economista Bhimrao Ramji Ambedkar, membro da casta "intocável", propôs que houvesse uma representação diferenciada dos segmentos populacionais considerados inferiores. Somente em 1950, a Constituição indiana instituiu, em seus artigos 15 e 16, as ações afirmativas, chamadas de "reserva" ou "representação seletiva" nas assembleias legislativas, na administração pública e nas redes de ensino (WEDDERBURN, 2005, p. 314 e 316).

${ }^{46}$ Disponível na página eletrônica <http://eeoc.gov/eeoc/history/35th/thelaw/eo-10925.html> (acesso em 27.12.2009): SECTION 301. Except in contracts exempted in accordance with section 303 of this order, all government contracting agencies shall include in every government contract hereafter entered into the following provisions:

"In connection with the performance of work under this contract, the contractor agrees as follows:
} 
oportunidades iguais de trabalho. A seção 301, (1), da Ordem previu que todas as empresas que contratassem com o governo federal deveriam, dentre outras previsões enumeradas na referida ordem, não discriminar qualquer empregado ou candidato ao trabalho em razão de sua raça, credo, cor ou origem. É nesse documento público que apareceu ineditamente o termo "affirmative action", ou "ação afirmativa", com o sentido de que os contratantes deveriam assegurar aos candidatos que fossem empregados e aos já empregados que fossem tratados sem consideração de sua raça, credo, cor ou origem. O mesmo item previu que a ação afirmativa deveria incidir sobre a escolha para o trabalho, a promoção, o rebaixamento e a transferência, o recrutamento e o anúncio do recrutamento, a dispensa e a rescisão, faixas de pagamento e outras formas de compensação, e seleção para treinamento, incluindo aprendizagem, dentre outros. Além disso, o contratante também deveria colocar em lugares visíveis, acessíveis aos empregados e aos candidatos, avisos sobre as medidas de ação afirmativa.

Inicialmente, a medida foi usada para evitar que negros não fossem selecionados para postos de trabalho, ou para evitar que negros só fossem selecionados para postos de trabalho com menor responsabilidade e remuneração. Tanto a escolha de uma pessoa para um trabalho quanto as decisões para a sua progressão na carreira deveriam ser "colorblind", ou cegas à cor.

Marcou ainda essa nova política de Estado a Lei de Direitos Civis de $1964^{47}$, que, dentre outras previsões, proibiu a discriminação no trabalho com base na raça, cor, religião, sexo ou origem, no Título VII. A Lei não tratou especificamente de políticas de ações afirmativas, mas foi um importante marco normativo na direção da eliminação de qualquer discriminação de ordem racial.

Até esse momento, o conceito de ações afirmativas aparecia como uma medida proibitiva de discriminação, ainda ligada à ideia da igualdade em seu sentido formal. Mas essa ligação passou aos poucos a ser mais frouxa, pois, mesmo que a lei ainda falasse em

\footnotetext{
"(1) The contractor will not discriminate against any employee or applicant for employment because of race, creed, color, or national origin. The contractor will take affirmative action to ensure that applicants are employed, and that employees are treated during employment, without regard to their race, creed, color, or national origin.

Such action shall include, but not be limited to, the following: employment, upgrading, demotion or transfer; recruitment or recruitment advertising; layoff or termination; rates of pay or other forms of compensation; and selection for training, including apprenticeship. The contractor agrees to post in conspicuous places, available to employees and applicants for employment, notices to be provided by the contracting officer setting forth the provisions of this nondiscrimination clause.

${ }^{47}$ Disponível na página http://uspolitics.about.com/od/usgovernment///bl_civil_rights_act_7.htm (acesso em 27.12.2009):
} 
proibição de discriminação, sutilmente começava a introduzir medidas positivas, como a obrigação de os contratantes publicarem avisos sobre a sua política de não-discriminação.

Em junho de 1965, falando a uma audiência predominante negra na Howard University $^{48}$, o Presidente Lyndon Johnson definiu o que seria justiça para aqueles grupos que por décadas sofreram algum tipo de discriminação racial:

Você não toma uma pessoa que, por anos, esteve presa por correntes e a libera, a traz para o início da linha de partida de uma corrida e diz: "você está livre para competir com todos os outros', e ainda crê que foi completamente justo. (ANDERSON, 2002, p. 11) (tradução da autora ${ }^{49}$ )

O então presidente completou que, para ser justa, a nação precisava avançar passos afirmativos a fim de incluir os negros nas instituições sociais dominantes, ir de uma mera igualdade de direito e de teoria para uma igualdade de fato e de resultado ${ }^{50}$. As políticas institucionais do Presidente ${ }^{51}$ ficaram conhecidas como "affirmative action", essas sim indo além de medidas proibitivas de discriminação.

Ao final dos anos 1960, instituições de ensino superior implementaram algum tipo de programa com o intuito de incluir mais estudantes negros nas universidades. Esses programas passaram gradualmente a prover bolsas de estudo, bem como apoio acadêmico, para ajudar os novos estudantes a melhor se adaptarem ao campus. No verão de 1968, uma política de ação afirmativa foi implementada na Universidade de Washington, localizada no estado americano de mesmo nome. Funcionários da universidade e membros da Associação de Estudantes Negros (Black Students Unions) viajaram pelo Estado encorajando estudantes de grupos minoritários a se candidatarem à UW. Foi criado o Programa das Oportunidades Iguais (Equal Opportunity Program, ou EOP), destinado a

\footnotetext{
${ }^{48}$ Howard University foi uma das universidades criadas para atender estudantes negros, em 1867, na cidade de Washington D.C., pois até 1954 vigorou a doutrina "separados mas iguais" (ou "separate but equals"). Uma das consequências dessa política era a proibição de negros estudarem com brancos em escolas públicas. Com a decisão do caso Brown v. Board of Education, pela Suprema Corte, os negros puderam, então, estudar nas mesmas escolas que os brancos.

${ }^{49}$ No original: "You do not take a person who, for years, has been hobbled by chains and liberate him, bring him up to the starting line in a race and then say, 'you are free to compete with all others', and still justly believe that you have been completely fair.".

50 À época e ainda nos dias atuais, críticos da ação afirmativa consideram a igualdade de resultados uma perversão da igualdade de oportunidades, pois a ênfase dada à efetividade dos resultados comprometeria uma ênfase na qualidade e na performance.

${ }^{51}$ O Presidente Johnson editou a Ordem Executiva n. 11246, em setembro de 1965, que utilizou os mesmos termos da Ordem Executiva do Presidente Kennedy, no que diz respeito à proibição de discriminação no trabalho em razão da raça, da cor, da religião, do sexo e da origem. Disponível em: http://www.dol.gov/esa/ofccp/regs/statutes/eo11246.htm. Acesso em: 27.12.2009.
} 
avaliar as admissões desses estudantes, bem como de estudantes que se encontravam em algum tipo de desvantagem econômica ou educacional (BALL, 2000, p. 5).

Nesse contexto, uma nova ideologia foi identificada com a diversidade cultural nos campi das universidades: salientou-se a importância de um corpo discente composto por diferentes etnias, culturas e posições sociais, como um reflexo de uma sociedade cada vez mais diversa e de um mundo cada vez mais globalizado. A diversidade era defendida por enriquecer a experiência educacional ao oferecer aos estudantes a possibilidade de aprender com vivências, crenças, valores e perspectivas diferentes das suas próprias; ao promover o crescimento pessoal com o desafio da quebra de preconceitos e estereótipos; ao fortalecer comunidades com o estímulo ao respeito mútuo e ao trabalho em equipe; além de potencializar a competitividade econômica do país fazendo uso efetivo do leque de diferentes talentos e habilidades de seus cidadãos.

Como uma das consequências das ações afirmativas nas universidades, muitos candidatos brancos que tiveram suas admissões negadas alegaram que eles eram vítimas inocentes de uma discriminação inversa. E, por isso, processaram essas instituições de ensino, como foi o caso Bakke v. Regents of the University of California, de 1978, o mais conhecido e emblemático no que diz respeito à discussão sobre a constitucionalidade das ações afirmativas para negros nas universidades norte-americanas.

A Escola de Medicina da Universidade da Califórnia instituiu um programa de ação afirmativa com o intuito de admitir mais estudantes negros e de outras minorias, destacando, para esses, dezesseis vagas em cem. Allan Bakke, branco, candidatou-se a uma das oitenta e quatro vagas restantes e foi rejeitado. No entanto, como as notas de seus testes eram relativamente altas, a Escola não conseguiu demonstrar que ele teria sido rejeitado do mesmo jeito se tivesse concorrido às cem vagas totais. Na teoria, Bakke teria atingido o número de pontos necessários para entrar na universidade. Em razão disso, ele ajuizou uma ação contra a universidade, alegando que teria tido seus direitos constitucionais violados. $\mathrm{O}$ caso chegou à Suprema Corte Federal, após recurso da universidade quando o Supremo Tribunal da Califórnia deu razão ao autor. A Suprema Corte declarou as cotas inconstitucionais, por constituírem critérios muito rígidos, mas, no entanto, considerou legítimas as medidas de ações afirmativas, desde que flexíveis e que tivessem por objetivo promover a diversidade no corpo discente. Em outras palavras: 
poderia ser considerada nas admissões se fosse sopesada com outras características em um processo comparativo. (tradução da autora ${ }^{52}$ )

Se um caso a ser analisado pela justiça americana envolve uma chamada classe suspeita - um grupo de pessoas que está ou foi sujeito a uma história de tratamento desigual proposital, ou relegado a uma posição de impotência política - então a decisão deve se sujeitar a um escrutínio estrito. Ou seja, deve ser rejeitada porque viola a Cláusula de Igual Proteção (regra) a não ser que seja possível provar que a desvantagem é essencial para proteger algum interesse de "irresistível" importância para o governo (exceção). Mas se a lei não prejudicar uma classe suspeita, a presunção é de constitucionalidade (regra) a não ser que se demonstre que a lei é inútil (exceção) - corresponde ao escrutínio "frouxo".

Dworkin explica que há quem defenda a aplicação do escrutínio estrito na análise das ações afirmativas, mas há quem defenda a aplicação do escrutínio frouxo, pois, por mais que raça seja um fator presente, o grupo prejudicado (os brancos) não constitui uma classe suspeita, ou seja, uma classe vítima de preconceito. O autor, por fim, defende que simplesmente se abandone a estratégia do escrutínio nessa análise. Isso porque essa estratégia foi criada para identificar leis que envolvam alto risco de discriminação e hostilidade e "os programas sensíveis à raça que sejam, à primeira vista, criados para ajudar um grupo racial que esteja em desvantagem não recaem em nenhuma dessas categorias..." (2005, p. 588).

Depois do caso Bakke, houve mais dois casos significativos que envolveram a discussão sobre ações afirmativas para negros nas universidades norte-americanas.

O caso Gratz v. Bollinger, decidido em 2003, assim como Bakke, considerou a raça como um critério possível de ser usado sob determinadas condições. Dois candidatos (Gratz e Hamacher), ambos brancos e moradores de Michigan, processaram o Colégio de Literatura, Ciências e Artes da Universidade de Michigan, pois não foram admitidos. No processo seletivo, a universidade considerava diferentes fatores, tais como notas, currículo, relações dos candidatos, localização, e raça. Aos candidatos pertencentes a minorias subrepresentadas (negros, por exemplo) concedia automaticamente vinte pontos, sendo que eram necessários cem pontos para a admissão. Na sua defesa, a universidade lembrou o caso Bakke, e se defendeu alegando que um dos seus objetivos era alcançar a diversidade estudantil. A Suprema Corte, no entanto, ainda que tenha consolidado o entendimento de

\footnotetext{
${ }^{52}$ No original: "Race could be deemed a 'plus', yet not insulate the applicant from comparison with all other candidates for the available seats... Race could be considered in admissions if it was factored in with other characteristics in a competitive process". (Regents of the University of California versus Bakke, 438 US 265, 1978, p. 2)
} 
que o fator raça pode ser usado, considerou que, no caso em questão, a atribuição de vinte dos cem pontos necessários equivaleria praticamente a uma reserva de vagas, pois teria o efeito de transformar a raça em um fator decisivo. Além disso, o argumento a favor do uso da raça do Justice Powell, no caso Bakke, significava que cada candidato deveria ser avaliado individualmente, e que raça poderia ser um "plus", mas não uma garantia automática da vaga.

Já o caso Grutter v. Bollinger, julgado em 2003, tratou de uma candidata, também branca e residente de Michigan, que processou a Faculdade de Direito da Universidade de Michigan quando não foi admitida. O processo de seleção da universidade consistia em selecionar alunos a partir de suas notas, talentos, experiências e potenciais. Não definia diversidade somente em termos de raça ou etnia, mas afirmava o compromisso de inclusão de afro-americanos, latinos e americanos nativos, que, de outra forma, não estariam bem representados em números significativos. $\mathrm{O}$ argumento principal de Grutter era que a faculdade estaria usando a raça como fator predominante. A Suprema Corte, no entanto, decidiu que a faculdade possuía um interesse legítimo (a diversidade do corpo estudantil) e que o programa de admissão era suficientemente flexível por considerar cada candidato individualmente, sendo raça apenas um fator a mais, mas não decisivo.

Conclui-se, pelos três casos expostos, que as políticas de ações afirmativas nas universidades norte-americanas são consideradas constitucionais quando i) a universidade possui o legítimo interesse de promover a diversidade no seu corpo estudantil, e ii) o candidato é considerado em sua individualidade. Ou seja, nesse ponto, o candidato não pode ser somente considerado como pertencente a um determinado grupo, mas deve ter todas as suas características consideradas. E isso só é possível em um processo de admissão que não seja constituído apenas de provas objetivas, como acontece no Brasil, em regra, mas também de avaliações subjetivas.

\subsection{Ações afirmativas nas universidades no Brasil}

No Brasil, o debate sobre a implantação de ações afirmativas no ensino não é recente, pois desde o início do século passado o movimento negro já entendia que não bastava o fim da escravidão, a proibição legal e formal de condutas discriminatórias para que o negro estivesse na mesma condição do branco. São conhecidos os cursinhos pré- 
vestibulares voltados não só às pessoas de baixa renda, mas também, com mais foco, à população negra.

A Constituição de 1988 já trouxe o conceito das ações afirmativas, ao prever, no seu artigo 37, inciso VIII, a reserva de vagas para pessoas com deficiência nos cargos e empregos públicos.

No Seminário Internacional sobre Multiculturalismo e Racismo, ocorrido em 1996, o então Presidente Fernando Henrique Cardoso declarou que

[o preconceito racial] tem que ser desmascarado. Tem que ser, realmente, contraatacado, não só em termos verbais, mas também em termos de mecanismos e de processos que possam levar a uma transformação na direção de uma relação mais democrática entre as raças, entre os grupos sociais, entre as classes. (SOUZA apud TELLES, 2003, p. 78)

Também em 1996, para dar concretude à sua declaração, foi criado o Plano Nacional de Direitos Humanos, que teve sua regulamentação somente em 2002, com a criação do Programa Nacional de Direitos Humanos. Entre as propostas gerais sobre igualdade, estava "86. Apoiar a adoção, pelo poder público e pela iniciativa privada, de políticas de ação afirmativa como forma de combater a desigualdade”. Já entre as propostas para afrodescendentes, o Programa previa:

155. Adotar, no âmbito da União, e estimular a adoção, pelos estados e municípios, de medidas de caráter compensatório que visem à eliminação da discriminação racial e à promoção da igualdade de oportunidades, tais como: ampliação do acesso dos afrodescendentes às universidades públicas, aos cursos profissionalizantes, às áreas de tecnologia de ponta, aos cargos e empregos públicos, inclusive cargos em comissão, de forma proporcional a sua representação no conjunto da sociedade brasileira.

156. Criar bancos de dados sobre a situação dos direitos civis, políticos, sociais, econômicos e culturais dos afrodescendentes na sociedade brasileira, com a finalidade de orientar a adoção de políticas públicas afirmativas.

157. Estudar a viabilidade da criação de fundos de reparação social destinados a financiar políticas de ação afirmativa e de promoção da igualdade de oportunidades.

158. Apoiar as ações da iniciativa privada no campo da discriminação positiva e da promoção da diversidade no ambiente de trabalho. (grifo da autora)

Em setembro de 2001 foi realizada a III Conferência Mundial de Combate ao Racismo, Discriminação Racial, Xenofobia e Intolerância Correlata, em Durban, África do $\mathrm{Sul}^{53}$. Com a Conferência, ganhou força a teoria de responsabilização dos Estados onde a

\footnotetext{
${ }^{53}$ Em abril de 2009 foi realizada a Conferência de Revisão de Durban, em Genebra, Suiça, onde foi avaliado o progresso das metas estabelecidas na III Conferência e onde as nações reforçaram o compromisso em torno
} 
escravidão existiu pelos danos causados, direta ou indiretamente, aos descendentes dos escravos. ${ }^{54} \mathrm{O}$ artigo 56 da Declaração de Durban aborda aquelas situações onde não houve ou não há discriminação declarada, como no Brasil pós-escravidão:

56. Reconhecemos a existência em muitos países de uma população mestiça com diversas origens étnicas e raciais e sua valiosa contribuição para a promoção da tolerância e do respeito nessas sociedades, e condenamos a discriminação de que é vítima, especialmente porque a natureza sutil dessa discriminação pode fazer que se negue a sua existência.

A Declaração vai além, ao reconhecer a escravidão como uma das principais fontes do racismo e da discriminação racial atuais:

18. Realçamos que a pobreza, o subdesenvolvimento, a marginalização, a exclusão social e as desigualdades econômicas estão estritamente vinculadas com o racismo, a discriminação racial, a xenofobia e as práticas conexas de intolerância e contribuem para a persistência de atitudes e práticas racistas, que por sua vez geram mais pobreza.

E, finalmente, reafirma a importância das ações afirmativas:

108. Reconhecemos a necessidade de adotar medidas afirmativas ou medidas especiais em favor das vítimas do racismo, da discriminação racial, da xenofobia, e das formas conexas de intolerância para promover sua plena integração na sociedade. Essas medidas de ação efetiva que hão de incluir medidas sociais, devem estar destinadas a corrigir as condições que minimizaram a fruição dos direitos e a introduzir medidas especiais para permitir a igual participação de todos os grupos raciais e culturais, lingüísticos e religiosos em todos os setores da sociedade, e para situá-los em pé de igualdade. Entre essas medidas deveriam figurar medidas especiais para lograr uma representação apropriada nas instituições de ensino, de habitação, nos partidos políticos, (...)

Em 2003, com forte influência do movimento negro, foi criada a Secretaria Especial de Políticas de Promoção da Igualdade Racial da Presidência da República Seppir.

do cumprimento da Declaração e Plano de Ação de Durban, com o revigoramento das ações, iniciativas e soluções práticas no combate ao racismo.

${ }^{54}$ Explica Joaquim Barbosa Gomes, com relação ao pensamento dominante até a Conferência de Durban: "Embora a noção de justiça compensatória figure como justificativa filosófica de um grande número de programas de ação afirmativa vigentes nos diversos países que adotam esse tipo de política social, inclusive nos Estados Unidos, do ponto de vista estritamente jurídico, porém, trata-se de uma concepção não isenta de falhas. Com efeito, em matéria de reparação de danos, o raciocínio jurídico tradicional opera com categorias rígidas tais como ilicitude, dano e remédio compensatório, estreitamente vinculados uns aos outros em relação de causa e efeito. Em regra, somente quem sofre diretamente o dano tem legitimidade para postular a respectiva compensação. Por outro lado, essa compensação só pode ser reivindicada de quem realmente praticou o ato ilícito que resultou no dano..." (apud VIEIRA JUNIOR, 2005, p. 84). 
O estado do Rio de Janeiro foi pioneiro em elaborar leis, a partir do final de 2000, para que as suas universidades públicas começassem a implementar, na seleção para os seus cursos, alguma medida de ação afirmativa para a população de baixa renda, para a população negra, ou para ambas. Desde então, as universidades têm usado algumas formas de ações afirmativas, dentre as quais a mais conhecida é o sistema de $\operatorname{cotas}^{55}$.

As cotas correspondem a uma reserva de parte das vagas disponíveis em um processo seletivo para que um grupo de pessoas com uma ou mais características comuns concorra a elas, separadamente dos demais grupos que não possuam essas características. Por exemplo, aquelas pessoas que se autodeclararem negras (característica comum entre elas) concorrerão a uma parte das vagas, e as pessoas que não se autodeclararem negras concorrerão às demais vagas. A escolha de qual característica será determinante para concorrer a essas vagas reservadas pode depender de diversos fatores, dentre os quais, a título ilustrativo, o desejo da universidade em formar um certo perfil de corpo discente e a existência de normas que obriguem as universidades a estabelecer um determinado processo seletivo. Pode-se pensar em cotas raciais, em cotas sociais, em cotas raciais e sociais independentes, e em cotas raciais e sociais sobrepostas. Esses são apenas exemplos, cujo rol pode ser expandido a depender das necessidades históricas e da criatividade humana.

Segundo dados do Instituto de Pesquisa Econômica Aplicada (Ipea) (2007, p. 218), vinte e uma instituições de ensino superior optaram por cotas raciais e sociais sobrepostas, ou seja, para concorrer às vagas reservadas, um candidato deve tanto se autodeclarar negro como ter estudado em escola pública, ou ter determinada renda média mensal, ou preencher outro critério definido pela universidade. Dez instituições adotaram somente as cotas sociais. Há ainda um terceiro grupo de sete universidades, que adotaram as cotas raciais e as cotas sociais de formas independentes. Isso quer dizer que há dois grupos de vagas reservadas, e o candidato negro pode concorrer a um dos grupos, e o candidato egresso de escola pública concorre a outro grupo.

O mesmo estudo do Ipea exemplifica os tipos de cotas com algumas universidades brasileiras (2007, p. 221-225). Toma-se, aqui, a liberdade de reproduzir os exemplos.

A Universidade de Brasília (UnB) implementou cotas raciais, ao adotar a reserva de $20 \%$ das vagas totais para alunos negros (pretos e pardos). Pelo seu sistema, o candidato que concorrer às vagas reservadas deve ser negro, autodeclarando-se assim, e optar pelo

\footnotetext{
${ }^{55}$ Segundo dados colhidos pelo Ipea em 2007, 43 universidades no país já implementaram o sistema de cotas em seus processos seletivos. (2007, p. 218)
} 
sistema no ato da inscrição no processo seletivo. Segundo o que consta na página eletrônica da Universidade ${ }^{56}$, o candidato deve obter, no mínimo, as seguintes notas para ser classificado:

- Nota maior que zero na prova de língua estrangeira;

- $10 \%$ da nota na prova de Linguagens e Códigos e Ciências Sociais;

- $10 \%$ da nota na prova de Ciências da Natureza e Matemática;

- $20 \%$ da nota no conjunto das provas.

Depois de feita toda a classificação é que as vagas reservadas serão ocupadas. Os candidatos que concorreram às vagas reservadas, mas que tiveram notas superiores às dos candidatos que não concorreram às vagas reservadas, ocuparão as vagas não reservadas.

Um exemplo de cotas raciais e sociais independentes é o caso da Universidade Federal do Paraná (UFPR), que reservou 20\% das vagas para alunos egressos do sistema público de ensino (nível fundamental e médio) e $20 \%$ das vagas para alunos negros, ficando, ainda, aberta a possibilidade de reserva de vagas para indígenas, se houver demanda. Há ainda a garantia de uma vaga no curso para pessoa com deficiência. Uma observação feita no edital $^{57}$ prevê que aqueles que já possuem uma graduação em nível superior não podem concorrer às vagas reservadas. Por esse sistema, então, o candidato negro pode concorrer a vagas reservadas $(20 \%)$, independente de ter estudado em escola da rede pública. De outro lado, o candidato que estudou em escola do sistema público pode concorrer a vagas reservadas (20\%), independente de ser negro.

Como exemplo de cotas raciais e sociais sobrepostas temos a Universidade Federal da Bahia (UFBA). Segundo consta em sua página eletrônica ${ }^{58}$, há seis possibilidades de categorias de inscrição para concorrer às vagas disponíveis, sendo a primeira delas o exemplo de cota racial e social sobreposta:

- Categoria A (36,55\%): candidatos de escola pública que se declararam pretos ou pardos.

- Categoria B (6,45\%): candidatos de escola pública de qualquer etnia ou cor.

- Categoria $C$ : candidatos de escola particular que se declararam pretos ou pardos.

- Categoria D (2\%): candidatos de escola pública que se declararam índiodescendentes.

\footnotetext{
${ }^{56}$ Disponível na página: http://www.unb.br/admissao/sistema_cotas/index.php. Acesso em: 05.01.2009.

57 Essa previsão está na página 30 do documento eletrônico disponível na página http://www.nc.ufpr.br/concursos_institucionais/ufpr/ps2009/documentos/guia_ps2009.pdf. Acesso em: 06.01.2009

${ }^{58}$ Disponível na página: http://www.vestibular.ufba.br/cotas/Cotas.htm. Acesso em: 06.01.2009.
} 
- Categoria E (55\%): todos os candidatos, qualquer que seja a procedência escolar e a etnia ou cor.

- Categoria F (eventualmente duas vagas extras): candidatos de escola pública que se declararam índios aldeados ou moradores das comunidades remanescentes dos quilombos.

Se as vagas reservadas para os candidatos negros de escola pública (categoria A) e as vagas reservadas para candidatos de escola pública de qualquer cor ou etnia (categoria B) não forem todas preenchidas, as remanescentes serão preenchidas por candidatos negros que tenham estudado em escola particular (categoria C). Caso ainda sobrem vagas, elas serão preenchidas por candidatos de qualquer cor ou etnia e de qualquer procedência escolar (categoria E).

Se as vagas reservadas para candidatos de escola pública que se declararam descendentes de índio não forem todas preenchidas, as remanescentes serão preenchidas por candidatos de qualquer cor ou etnia e de qualquer procedência escolar (categoria E).

Além dessas reservas de vagas, há a garantia de abertura de duas vagas extras por curso, além do total oferecido, para candidatos oriundos da rede pública de ensino e que tenham se declarado índios aldeados ou moradores das comunidades remanescentes de quilombos.

A UFBA explica que os candidatos serão classificados dentro de cada categoria de inscrição, e selecionados na ordem de classificação e ainda esclarece, na sua página, que:

10) Observe-se que as categorias de inscrição não são mutuamente exclusivas. $\mathbf{A}$ é subconjunto de $\mathbf{B}$, que, por sua vez, é subconjunto de $\mathbf{E}$. Assim, um candidato com inscrição de Categoria $\mathrm{A}$, se não selecionado, continua concorrendo na Categoria $\mathrm{B}$ e, se não selecionado, ainda concorre na Categoria E. Obviamente, ele concorre em igualdade de condições (exclusivamente pelo desempenho acadêmico) com todos os candidatos da categoria de inscrição na qual está efetivamente concorrendo.

11) Para a segunda fase, são classificados candidatos em número equivalente ao triplo do número de vagas oferecidas em cada curso, considerando-se cada uma das categorias de inscrição anteriormente mencionadas.

Feita essa brevíssima explicação de alguns exemplos de sistemas de cotas adotados por algumas universidades brasileiras, também merece um esclarecimento, em poucas linhas, outra espécie de ação afirmativa, chamada de "bonificação".

Basicamente, por esse sistema todos os candidatos concorrem às mesmas vagas, só que alguns candidatos, por possuírem determinadas características predefinidas, recebem uma bonificação (por exemplo, em um sistema de vestibular, alguns pontos a mais). É possível existir, por exemplo, uma bonificação para candidatos autodeclarados negros e 
para candidatos oriundos de escolas da rede pública. Esse sistema é bastante similar a alguns métodos adotados por universidades norte-americanas, que fazem um "check list", pelo qual a comissão julgadora atribui pontos a características dos candidatos (podendo as características ter pesos distintos).

No Brasil, a Universidade de Campinas (Unicamp) foi pioneira ao aplicar esse sistema, em 2004. Podem se beneficiar da bonificação os candidatos que tenham cursado todo o ensino médio em escolas públicas no Brasil. Esses candidatos receberão, de forma automática, trinta pontos a mais na nota final, após a realização da segunda fase do processo seletivo. Além disso, aqueles que se declararem negros (pretos e pardos) ou indígenas e que tenham cursado todo o ensino médio em escolas públicas receberão, além dos trinta pontos a mais, outros dez na nota final.

\subsection{Principais argumentos contrários e favoráveis às ações afirmativas nas universidades}

A partir do que foi exposto sobre o princípio da igualdade e as políticas de ações afirmativas, serão apresentados, neste momento e de forma resumida, alguns dos principais argumentos contrários a essas políticas, seguidos de explicações que tentam desconstruílos.

Reconhece-se que é difícil abarcar todos os pontos de conflito envolvendo ações afirmativas e que cada um deles mereceria até mesmo uma tese específica, visto que há questões de ordem sociológica, econômica, filosófica etc. por trás de cada um. Além disso, o objetivo desta dissertação não é esgotar cada um desses argumentos, mas sim apresentar a discussão sobre a igualdade e as políticas de ações afirmativas, e, com base no estudo de caso dos julgados do Tribunal de Justiça do Rio de Janeiro, propor uma realocação da discussão até então travada nos ambientes não só acadêmicos, mas também no senso comum da sociedade. Assim, pretende-se com este capítulo contextualizar o que parecem ser os principais pontos polêmicos da discussão, à luz da teoria aqui exposta. Essa contextualização é necessária para a própria análise dos julgados que será feita na segunda parte deste trabalho. 


\subsubsection{O ingresso na universidade deve ter como critério exclusivo o mérito}

Entre os argumentos contrários às políticas de ações afirmativas nas universidades está que o estudante deve ter mérito para estudar no curso superior, e, tendo em vista que não há número de vagas suficiente para todos, a seleção deve ser feita com base em um sistema que selecione aqueles que, em tese, estão mais bem preparados.

Mas, afinal, o que é mérito? É possível defender que um aluno com mais privações sociais e econômicas que faça, por exemplo, $55 \%$ dos pontos em um teste seja menos qualificado, ou possua menos mérito, que um aluno que teve acesso a uma educação de qualidade, em sentido amplo, que faça, por exemplo, 70\% dos pontos do mesmo teste. Ao contrário, é possível afirmar que o primeiro é mais bem qualificado do que o segundo e, por isso, não configuraria discriminação ou violação dos direitos do segundo aceitar o primeiro candidato.

Segundo Telles,

os críticos [às cotas e às políticas raciais] partem do princípio de que a admissão à universidade, que é totalmente baseada apenas no resultado de provas de admissão (o vestibular), é inequivocadamente baseada em mérito. Entretanto, passar no vestibular parece ter muito mais relação com a habilidade do candidato em pagar cursinhos, geralmente caros, de preparação para vestibular e em dedicar um ano ou mais inteiramente aos estudos para as provas, do que da [sic] habilidade em ter êxito na faculdade. (2003, p. 287)

O autor complementa que a meritocracia é utópica nesse contexto, pois a "admissão à universidade parece, então, ser muito mais uma 'testocracia' do que uma 'meritocracia'." (2003, p. 287) e ainda cita Amartya Sen, para quem o mérito é condicionado à definição imposta pelos grupos sociais dominantes.

\footnotetext{
As instituições precisam definir o que é sucesso a longo prazo, pois esta é, basicamente, uma questão de valores sobre o que é importante: o desempenho no curso? A eficiência no exercício da profissão? A prestação de serviço e a liderança para as comunidades pobres? Ou servir de exemplo para os jovens? Talvez seja necessário definir melhor o que é bem social, para que seja possível decidir quem deve ser admitido na universidade. (TELLES, 2003, p. 287-288)
}

O candidato não tem o direito de insistir que inteligência seja o único critério de admissão a ser levado em conta. O conjunto da comunidade poderá estar mais bem servido se os graduados nas diversas universidades forem inteligentes, humildes, tolerantes, 
sensíveis, determinados, esforçados etc. Em outras palavras, os critérios admissionais se justificam não porque premiam os mais inteligentes, mas porque devem buscar servir a uma política social útil (DWORKIN, 2002, p. 347). Essa utilidade é relativa, depende dos objetivos que uma sociedade quer alcançar, e uma pista para saber quais são essas metas é a Constituição de uma nação.

Complementando essa ideia, para Dworkin, a qualificação [em algumas situações] é questão de possibilidades futuras, e não de realizações passadas ou de dotes naturais.

\begin{abstract}
Os responsáveis pelas admissões [nas universidades] não devem oferecer as vagas como prêmios por realizações ou trabalhos passados, nem como medalhas por talentos ou virtudes inerentes: seu dever é tentar escolher um corpo discente que, no todo, venha a dar a maior contribuição possível às metas legítimas que a instituição definiu. (...) As universidades públicas e as faculdades têm, portanto, responsabilidades públicas: devem escolher metas que beneficiem uma comunidade muito mais ampla do que seus próprios corpos docente e discente. (DWORKIN, 2005, p. 569)
\end{abstract}

Para o autor Peter Singer, os interesses dos candidatos não têm porque serem levados em consideração, visto que é a universidade que tem um interesse em possuir um determinado corpo discente. Assim, é a universidade que escolhe quais alunos quer admitir, de acordo com um objetivo anteriormente firmado, a partir do qual são elaborados critérios de seleção. Esse objetivo pode ser, por exemplo, alcançar a diversidade estudantil, e não necessariamente possuir os alunos que tenham as melhores notas (SINGER, 2002, p. 57). O autor acrescenta que a própria inteligência não traz um direito inerente à admissão maior do que a raça ou etnia. Isso, pois o critério será justo e legítimo se estiver de acordo com os objetivos e finalidades da universidade. É uma regra técnica pela qual há um meio para se alcançar determinado resultado pré-estabelecido.

Para Ronald Dworkin, não é possível falar em mérito em um sentido abstrato, pois, assim como também já explicou Singer, o mérito e os critérios escolhidos para a admissão dependem antes dos objetivos e finalidades que a universidade quer alcançar (2000, p. 445446).

Dworkin ainda pondera que qualquer processo de admissão faz generalizações, com base em estatísticas. Por exemplo, o estabelecimento de uma nota de corte configura uma generalização, e os candidatos que ficam abaixo dessa nota sequer são chamados para as entrevistas. $\mathrm{O}$ mesmo acontece com o estabelecimento de idade: no caso norte-americano Bakke, o candidato foi recusado em outras duas escolas em razão da sua idade (ele tinha trinta e três anos). Essas escolas não basearam sua decisão em uma investigação detalhada 
da vida do candidato, mas sim em uma suposição genérica que um candidato mais jovem poderia ser mais útil como médico. Certo ou errado, não se questiona se essas duas escolas violaram o direito de Bakke de ser avaliado como indivíduo ${ }^{59}$. Para o autor,

\begin{abstract}
os critérios raciais não são necessariamente os padrões corretos para decidir quais candidatos serão aceitos pelas faculdades de direito, mas o mesmo vale para os critérios intelectuais ou para quaisquer outros conjuntos de critérios. A equidade - e a constitucionalidade - de qualquer programa de admissões deve ser testada da mesma maneira. O programa estará justificado unicamente se servir a uma política adequada, que respeite o direito de todos os membros da comunidade de serem tratados como iguais. (2002, p. 368-369)
\end{abstract}

\title{
5.3.2 A qualidade do ensino universitário ficará prejudicada por um baixo desempenho
} dos alunos admitidos por meio de ações afirmativas

Esse argumento acompanha a lógica do exposto no primeiro item deste capítulo: o mérito do estudante costuma ser diretamente associado à qualidade do ensino: se um candidato não é aprovado com base no seu "mérito", a qualidade do ensino se deteriorará.

Do mesmo modo que se perguntou o que é mérito, pergunta-se, aqui, o que se quer dizer com qualidade de ensino. Somente respondendo a essa questão será possível aferir se essa qualidade cairá com a entrada de alunos cotistas na universidade.

Inicialmente, é preciso recuperar que há pelo menos um fato e algumas normas que precisamos ter em mente para tentar refutar o argumento deste item.

Os estudantes que ingressam em uma universidade por meio de políticas de ações afirmativas também passam por provas e exames, de modo que, sem conhecimentos mínimos sobre determinados assuntos, não conseguem aprovação - sendo assim, ainda que o conceito de mérito possa ser discutido, é difícil dizer que quem passa por uma seleção não possui qualquer mérito. O que ocorre é que grupos diferentes de pessoas concorrem entre si, eventualmente com notas de corte diferentes, e os membros de todos os grupos possuem chances de serem aprovados.

Além desse fato, existe um artigo na Constituição Federal - o art. $207^{60}$ - que estabelece estar a universidade igualmente fundada em três pilares indissociáveis: o ensino,

\footnotetext{
${ }^{59}$ Esse argumento não pode ser estendido diretamente para a realidade brasileira, em razão de o vestibular, aqui, consistir somente em avaliações objetivas. Mas o argumento é útil para questionar alguns pontos que tomamos como premissas, mas que podem não ser tão pacíficos como pensamos.
} 
a pesquisa e a extensão. Como não é objetivo discutir, neste âmbito, os diferentes possíveis sentidos desses três pilares, adota-se a interpretação simples e concisa da professora de psicologia e doutora em educação Lígia Márcia Martins, da Universidade Estadual Paulista:

\begin{abstract}
Esta organicidade pressupõe a formação superior como síntese de três grandes processos, quais sejam: processo de transmissão e apropriação do saber historicamente sistematizado, a pressupor o ensino; processos de construção do saber, a pressupor a pesquisa e os processos de objetivação ou materialização desses conhecimentos, a pressupor a intervenção sobre a realidade, e que, por sua vez, retornam numa dinâmica de retro-alimentação do ensino e da pesquisa. ${ }^{61}$ (grifos originais).
\end{abstract}

Um estudante pode se destacar mais no ensino, por exemplo, enquanto outro pode se destacar mais na pesquisa ou na extensão. Desse modo, novamente a conclusão é pela inexistência de mérito em sentido abstrato e pela afirmação de que a qualidade, de uma forma geral, depende da conjugação dos três pilares da universidade (e não, necessariamente, o sistema do vestibular é o meio mais eficaz de selecionar o candidato mais apto a ajudar a universidade a cumprir com as suas três funções básicas).

Outro artigo constitucional também merece ser citado nessa discussão sobre a qualidade do ensino: o art. $205^{62}$ delimita os três objetivos da educação, quais sejam, o pleno desenvolvimento da pessoa, sua preparação para o exercício da cidadania e sua qualificação para o trabalho. O método de seleção dos estudantes para compor o corpo discente deve ser construído de modo que sejam escolhidos os alunos que, de forma individual e coletiva, possam contribuir com o cumprimento desses objetivos, conjuntamente. $\mathrm{O}$ vestibular, como conhecemos, parece escolher somente os alunos que terão mais chance de se qualificarem tecnicamente para uma profissão, e uma seleção mais diversificada tende a ter mais chances de compor um corpo discente mais eclético, mais heterogêneo e mais apto a contribuir, em cada estudante, para seu pleno desenvolvimento e sua preparação para o exercício da cidadania.

José Afonso da Silva entende que

\footnotetext{
${ }^{60}$ Art. 207. As universidades gozam de autonomia didático-científica, administrativa e de gestão financeira e patrimonial, e obedecerão ao princípio de indissociabilidade entre ensino, pesquisa e extensão.

${ }^{61}$ Disponível na página: http://www.franca.unesp.br/oep/Eixo\%202\%20-\%20Tema\%203.pdf. Acesso em: 21.11.2009.

${ }^{62}$ Art. 205. A educação, direito de todos e dever do Estado e da família, será promovida e incentivada com a colaboração da sociedade, visando ao pleno desenvolvimento da pessoa, seu preparo para o exercício da cidadania e sua qualificação para o trabalho.
} 


\begin{abstract}
A consecução prática dos objetivos da educação consoante o art. 205 - pleno desenvolvimento da pessoa, seu preparo para o exercício da cidadania e sua qualificação profissional - só se realizará num sistema educacional democrático, em que a organização da educação formal (via escola) concretize o direito ao ensino, informado por princípios com ele coerentes, que realmente foram acolhidos pela Constituição, como são: igualdade de condições para o acesso e permanência na escola;... pluralismo de ideias e de concepções pedagógicas... (2000, p. 814)
\end{abstract}

Nesse sentido, a maior diversidade no perfil do alunado tende a melhor contribuir com a "consecução prática dos objetivos da educação", parafraseando José Afonso, na medida em que o inciso III do art. 206 da Constituição Federal - que prevê o princípio do pluralismo de ideias no ensino - é cumprido.

O ambiente universitário é responsável pela geração e pela difusão de conhecimento, e, de uma forma geral, é restrito a uma elite. Essa é uma das razões para que esse ambiente seja preenchido por um corpo discente que represente a diversidade social e cultural da sociedade brasileira.

É curioso notar que os pais de classe média/alta mandam seus filhos fazer intercâmbio em outros países, ou mesmo os universitários vão estudar em uma universidade estrangeira, justamente para aprender outro idioma ou disciplinas sob outro enfoque, ou conviver com outras culturas. Esse fenômeno comprova a importância do conhecimento múltiplo, da heterogeneidade, da diferença. Uma pergunta possível de ser feita, então, é: por que não ter toda essa convivência com diferenças aqui? Nas universidades norte-americanas, como já mencionado, a diversidade é uma qualidade buscada nos processos seletivos, pois se entende que

A diversidade é um fator de alta produtividade e versatilidade, pois multiplica as possibilidades de solução dos problemas, tomando como aporte resolutivo a experiência/acúmulo que cada segmento representado pode trazer. Um ambiente composto por pessoas com experiências históricas diferenciadas, acostumadas a lidar com a complexidade das diferenças, tem maior capacidade de responder às mais variadas tarefas e demandas com flexibilidade. (WEDDERBUM, 2005, p. 333)

Nos argumentos favoráveis às ações afirmativas, os benefícios da diversidade sempre aparecem. Por outro lado, alguém pode argumentar que o negro nem sempre é diferente do branco, ou tem uma cultura diferente. Pode até ter, o que sem dúvida enriquece o ambiente, mas isso não é necessariamente um fato certo. No entanto, o que ao final se deve ter em mente é que o negro não precisa ser integralmente diferente, podendo ser diferente somente no fenótipo. E é aí que reside o principal ponto, talvez, de toda a discussão: mesmo não sendo diferente em sentido amplo, pelo simples fato de ser negro, já 
há uma representação de "algo diferente", ou seja, um grupo de pessoas que não estão acostumadas a serem vistas em determinados espaços restritos, por diversos motivos, passados e presentes.

Para Dworkin,

\begin{abstract}
Os críticos argumentam que a seleção segundo critérios de raça é um modo inadequado de se procurar a diversidade, pois este presume, de maneira equivocada e ofensiva, que todos os alunos negros, e somente os negros, proporcionam a diversidade desejada em termos de classe social, atitudes políticas ou cultura: seria melhor, segundo esses críticos, aceitar alunos de qualquer raça cujos pais sejam pobres ou gostem de soul music, em vez de procurar alunos negros, alguns dos quais têm pais ricos ou preferem Bach.

Mas essa objeção não alcança o aspecto da diversidade em questão, que não é o que a raça pode ou não indicar, mas a própria raça. Infelizmente, os piores estereótipos, desconfianças, temores e ódios que ainda envenenam os Estados Unidos são codificados pela cor, e não pela classe ou pela cultura. É fundamental que os negros e os brancos se conheçam e se admirem, e se alguns negros não tiverem a classe, a cultura ou outras características que lhes sejam associadas por estereótipos, é óbvio que isso aumenta, em vez de destruir, as vantagens da diversidade racial. (2005, p. 571-572) (grifos da autora)
\end{abstract}

A educação proporciona um conhecimento que constitui uma das poucas armas que os negros têm para obter uma formação que posteriormente lhes permitirá fazer parte de espaços de decisão e poder político. A presença de professores e estudantes negros em espaços educativos permite a construção de uma sociedade mais democrática e plural, por causa das relações interculturais e o desenvolvimento de enfoques que irão permeando outros grupos étnico-raciais.

Com relação à "qualidade" dos alunos cotistas ${ }^{63}$, dados do Ipea, baseados em números disponibilizados pela Assessoria de Diversidade de Apoio aos Cotistas da UnB, indicam que:

\begin{abstract}
No que se refere ao desempenho, não se percebem diferenças significativas entre os alunos aprovados pelo sistema de cotas e os pelo sistema universal. Em aprovação nas disciplinas cursadas, os alunos cotistas apresentam um índice de $88,90 \%$ e os não-cotistas de $92,98 \%$. Quanto ao trancamento de matéria, o índice é de $1,73 \%$ para cotistas e $1,76 \%$ para não-cotistas. Na média geral do curso, que varia entre 0 e 5 , também se verifica que é pequena a desvantagem dos alunos cotistas em relação aos não-cotistas. O índice dos cotistas é de 3,57\%, enquanto os não-cotistas apresentam um índice de 3,79\%. (2007, p. 221)
\end{abstract}

Na página eletrônica da Secretaria de Comunicação da $\mathrm{UnB}^{64}$ é divulgado que:

\footnotetext{
${ }^{63} \mathrm{Na}$ página eletrônica http://www.comvest.unicamp.br/paais/paais.html (acesso em: 06.01.2009), pode-se conferir informações relativas ao desempenho acadêmico dos alunos que entraram com o uso do sistema de bonificação.

${ }^{64}$ Disponível na página: http://www.secom.unb.br/unbnoticias/un0908-p09.htm. Acesso em: 05.01.2009.
} 
Em 52 cursos, de um total de 61 analisados, o desempenho de cotistas e nãocotistas foi praticamente o mesmo. Os egressos da reserva de vagas, inclusive, superaram os do universal em 31 graduações. A diferença no desempenho dos dois grupos varia entre 0,1 e 0,3 pontos no Índice de Rendimento Acadêmico (IRA), que vai de 0 a 5 . Isso ocorre, principalmente, nos cursos de humanas e saúde, inclusive nos mais concorridos dessas áreas.

(...)

Os cotistas ficam atrás nos nove cursos mais valorizados das exatas. A média de desempenho é $11 \%$ menor em relação aos egressos do sistema universal, o equivalente a 0,5 pontos do IRA. As maiores discrepâncias foram nas engenharias Civil e Mecatrônica, em que tiveram notas bem inferiores, com médias $41 \%$ e $32 \%$ mais baixas, respectivamente.

(...)

Mesmo com desvantagens em alguns cursos, o índice de evasão entre os cotistas é menor. Em 2005, $11 \%$ dos estudantes da UnB abandonaram o curso. Entre os egressos da ação afirmativa, a taxa de evasão ficou em $6 \%$.

5.3.4 A ausência de alunos negros nas universidades tem como causa a deterioração do ensino público médio e fundamental, de modo que a prioridade deveria ser a melhoria desses níveis escolares. A desigualdade é de ordem social, e não racial, pois no Brasil existe uma democracia racial. Portanto, a solução viria de uma política voltada para a população pobre.

Esses dois pontos, apesar de distintos, serão tratados de forma conjunta, pois as suas lógicas são similares, e, portanto, o teor da fundamentação que procura rebatê-los também é parecido.

Ambos os pontos negam a existência de um problema racial no Brasil e apresentam como explicações para a ausência dos negros nas universidades e em outros espaços a qualidade ruim do ensino e a pobreza. Ou seja, coincidentemente os negros estudam em escolas ruins e são pobres. A solução para esse problema seria, então, a melhoria do ensino e a redução da pobreza. Com isso, os negros seriam beneficiados de forma indireta.

Peter Fry é um dos estudiosos que defende que a desigualdade é de ordem socioeconômica, e que uma política baseada na raça pode dividir o Brasil em duas raças. Ele resume essa ideia:

... tornou-se fácil produzir correlações duvidosas (se não espúrias) entre "raça" e certos sofrimentos, mesmo quando tudo indica que sejam resultantes de desigualdades de classe. O combate governamental ao racismo no Brasil parece ter colocado o anti-racismo em segundo plano para investir em políticas de ação 
afirmativa que afirmam, mais do que tudo, identidades 'raciais' e 'étnicas'. (2005-2006, p. 186)

Segundo Ricardo Henriques, a evolução da escolarização entre os grupos é semelhante, ou seja, todos se beneficiam com a escolarização, mas a desigualdade entre negros e brancos permanece:

\begin{abstract}
De acordo com os dados da Pesquisa Nacional por Amostra de Domicílios a escolaridade média de um jovem negro com 25 anos de idade gira em torno de 6,1 anos de estudo; um jovem branco da mesma idade tem cerca de 8,4 anos de estudo. O diferencial é de 2,3 anos. Apesar da escolaridade de brancos e negros crescer de forma contínua ao longo do século, a diferença de 2,3 anos de estudo entre jovens brancos e negros de 25 anos de idade é a mesma observada entre os pais desses jovens. E, de forma assustadoramente natural, 2,3 anos de estudo é a diferença entre os avós desses jovens. (HENRIQUES, CAVALLEIRO, 2005, p. 212)
\end{abstract}

Sobre o estudo feito por Henriques, no Ipea, Kabelenge Munanga comenta que se "por um passe de mágica o ensino básico e fundamental melhorarem seus níveis...os alunos negros levariam cerca de 32 anos para atingir o atual nível dos alunos brancos. Isso supõe que os brancos fiquem parados em suas posições atuais esperando a chegada dos negros" (2002, p. 125).

Percebe-se que políticas direcionadas aos ensinos fundamental e médio tenderão a melhorar, de uma forma geral, a qualidade da educação - e isso sem dúvida é fundamental - mas não necessariamente conseguirão resolver o problema da desigualdade entre brancos e negros. Uma das possíveis medidas a ser conjugada com as políticas de melhoria do ensino são as ações afirmativas, pois elas constituem justamente políticas de caráter temporário, que visam acelerar o processo de igualdade com foco em determinado grupo excluído, no caso aqui, dos negros.

Além disso, é preciso retomar o que já foi dito mais acima, com relação à diferença das ações afirmativas para as políticas de cunho universal. São políticas que possuem objetivos diferentes, e que podem e devem ser combinadas justamente porque visam atingir diferentes resultados. As políticas universais para reduzir a pobreza, para prover uma educação de qualidade para todos etc. devem ser permanentes. Por outro lado, as ações afirmativas, como já escrito algumas vezes neste trabalho, existem porque as políticas universais, ao atingir toda uma população, não dão conta, sozinhas, de atentar para diferenças de grupo. Ademais, os grupos vulneráveis não podem esperar o longo tempo necessário para que uma política universalista seja eficaz para todos. De uma forma 
ou de outra, é importante ter claro que um tipo de política não exclui a outra; pelo contrário, o ideal é que sejam implementadas juntas:

\footnotetext{
O debate é, assim, muitas vezes colocado como um conflito entre ações afirmativas de um lado e políticas universalizantes de outro, quando estas não são necessariamente antagônicas, podendo ser complementares em muitas situações. (FRISCHEISEN, 2007, p. 66-67)
}

Os negros confundem-se sim com pobres, e precisam de políticas que melhorem a sua situação socioeconômica e de medidas que visem atacar também o problema da ausência de reconhecimento, dos estereótipos e estigmas. É necessário que uma pessoa negra possa chegar a ser, por exemplo, secretário dos negócios jurídicos da prefeitura de São Paulo, como foi o caso de Edivaldo Brito, mas que ele não seja parado diversas vezes pela polícia quando está em seu carro oficial nas ruas (COSE, 1998, p. 42).

\subsubsection{Não existem raças e, por isso, não há sentido em políticas direcionadas a raças}

Não há mais dúvidas de que raça não existe entre os seres humanos. Ou seja, biologicamente, não faz sentido falar em raça branca, raça negra etc. Porém, enquanto o conceito de raça for usado socialmente, para fins de discriminação, é importante que esse mesmo conceito seja usado para fins de combate a essa discriminação, por mais ilógico que isso pareça ser. Isso é ainda mais importante no caso brasileiro, onde ainda perdura o mito da democracia racial. Ora, se abolirmos a palavra raça de nossos vocabulários, esse mito será reforçado, assim como os efeitos malignos da real discriminação. Ninguém falará em racismo, em discriminação ou preconceito racial, sob o argumento de que raça não é um conceito válido, e correr-se-á o risco de a sociedade ter a falsa percepção de que não existem práticas discriminatórias contra um determinado fenótipo.

Antonio Sergio Guimarães explica que

\footnotetext{
"raça" não é apenas uma categoria política necessária para organizar a resistência ao racismo no Brasil, mas é também categoria analítica indispensável: a única que revela que as discriminações e desigualdades que a noção brasileira de "cor" enseja são efetivamente raciais e não apenas de "classe" (Guimarães, 1999). (2002, p. 50)
} 
Celso Lafer produziu um parecer nos autos do habeas corpus 82.424-2, julgado em 2003 pelo Supremo Tribunal Federal, que tratou do suposto racismo praticado por Siegfried Ellwanger ao publicar livros cometendo o crime de incitamento contra os judeus. O advogado do réu alegou que não se poderia falar em crime de racismo, visto que os judeus não constituem uma raça, pois raça, afinal, não existe biologicamente.

Lafer, em seu parecer, concorda pela inexistência de raça em termos biológicos, mas ressalta que não se pode interpretar o crime de racismo a partir do conceito de raça, sob pena de esvaziar o que pretendeu a Constituição Federal e a legislação infraconstitucional. O professor entende que nos casos de direitos humanos o intérprete deve sempre favorecer o conteúdo do Direito e o bem que se quis proteger, sob pena de "numa situação-limite... converter o crime de prática do racismo em crime impossível pela inexistência do objeto" (2005, p. 49).

O autor discorre sobre o fundamento do crime de racismo:

Se o racismo não pode ser justificado por fundamentos biológicos, no entanto, persiste como fenômeno social. É este fenômeno social, e não a "raça", o destinatário jurídico da repressão prevista pelo art. $5^{\circ}$, XLII, da Constituição de 1988.... o conteúdo jurídico do crime de racismo tem o seu núcleo nas teorias e ideologias e na sua divulgação, que discriminam grupos e pessoas, a ela atribuindo as características de uma "raça" inferior. (2005, p. 28-59)

Dworkin concorda e explica que

\begin{abstract}
Em uma sociedade racista, as pessoas são de fato rejeitadas pelo que são e é, portanto, natural que as classificações raciais sejam encaradas como capazes de infligir um tipo de dano especial. Seria, contudo, cruel desaprovar o uso de tais classificações para combater o racismo, que é a verdadeira e constante causa de tais danos. O caráter psicológico especial da raça não é um fato fixo ao qual as políticas devam sempre respeitar. É um produto e sinal do racismo, e não se deve permitir que proteja o racismo que o gerou. (2005, p. 577)
\end{abstract}

O fato é que raça não existe biológica ou cientificamente, mas existe para os racistas e acaba existindo para as vítimas do racismo e da discriminação racial. Segundo Munanga, a ideologia racista não precisa de um conceito biológico de raça para se fazer e se reproduzir (informação verbal, 2009). O termo só poderá deixar de ser usado quando já não houver mais identidades raciais e quando as desigualdades, as discriminações e as hierarquias sociais não mais corresponderem às identidades raciais hoje existentes (GUIMARÃES, 2002, p. 50-51). 
5.3.6 Não há como definir quem é negro no Brasil. As ações afirmativas podem promover o oportunismo de pessoas que não correspondem aos povos ou grupos discriminados, pois há aqueles que nunca se identificaram como negros e assumem essa identidade étnica para serem beneficiados

Ainda que diferentes, essas duas afirmações usadas para criticar as ações afirmativas são apresentadas juntas, pois há argumentos similares que explicam porque elas são questionáveis.

Definir quem é branco e quem é negro no Brasil pode ser de fato difícil. O critério da autodeclaração é, até o momento, aquele que parece ser o mais bem aceito. Telles cita o argumento de um professor da UnB, para quem "pode até haver oportunismo 'branco' no uso das cotas raciais, mas que tais problemas não deveriam ser antecipados... [é necessário que] a eficácia das políticas, inclusive a extensão dos abusos, seja avaliada, depois de alguns anos". (TELLES, 2003, p. 291)

Se o medo é a fraude no sistema de autodeclaração, é pouco provável que a maioria dos alunos brancos se declare como negros apenas para ser destinatária das ações afirmativas. Segundo Munanga, o ideal do branqueamento ainda atua no imaginário coletivo (2002, p. 129), e, assim, ainda não existe uma cultura massificada de assumir uma identidade negra (por medo de preconceito, por ir contra os padrões institucionalizados pela sociedade, pelo fato de essa identidade não ser reconhecida etc.). Ou seja, assumir-se como negro pressupõe uma escolha que tem seus próprios riscos, não sendo uma questão pura e simples de manifestação.

É de fato possível que haja casos de pessoas não negras que se declarem negras apenas para concorrer pelo sistema de ações afirmativas. No entanto, são casos extremos ou particulares, e que acontecem ou poderão acontecer em uma escala tão pequena que, de modo algum, devem se sobrepor aos benefícios e ao alcance das ações afirmativas.

\section{Segundo Kabelenge Munanga,}

Num país onde existe discriminação antinegro, a própria discriminação é a prova de que é possível identificar os negros. Senão não teria discriminação. Em comparação com outros países do mundo, o Brasil é um país que tem um índice de mestiçamento muito mais alto. Mas isso não pode impedir uma política, porque basta a autodeclaração. Basta um candidato declarar sua afrodescendência. Se tiver alguma dúvida, tem que averiguar. Nos casos-limite, o 
indivíduo se autodeclara afrodescendente. Às vezes, tem erros humanos, como o que aconteceu na UnB, de dois jovens mestiços, de mesmos pais, um entrou pelas cotas porque acharam que era mestiço, e o outro foi barrado porque acharam que era branco. Isso são erros humanos. Se tivessem certeza absoluta que era afro-descendente, não seria assim. Mas houve um recurso e ele entrou. Esses casos-limite existem, mas não é isso que vai impedir uma política pública que possa beneficiar uma grande parte da população brasileira.

(...)

Se alguém comprovar que não tem mais racismo no Brasil, não devemos mais falar em cotas para negros. Deveríamos falar só de classes sociais. Mas como o racismo ainda existe, então não há como você tratar igualmente as pessoas que são vítimas de racismo e da questão econômica em relação àquelas que não sofrem esse tipo de preconceito. (2009)

$\mathrm{Na}$ hipótese de haver muitos erros ou fraudes no processo de seleção, ou de a autodeclaração não ser tão eficiente, dever-se-á, então, buscar outros métodos. O ser humano é criativo e não faltam experiências ao redor do mundo. O que não pode acontecer é, em razão de um eventual método falho, toda a política de ações afirmativas ser completamente invalidada.

5.3.7 Cotas e ações afirmativas vão permitir que se forme uma elite negra. A grande massa negra e pobre continuará excluída

As ações afirmativas não resolverão todos os problemas da grande massa negra, e nem possuem esse intuito. São sempre necessárias outras medidas que caminhem junto, como as de caráter universalista, para atacar a desigualdade social e racial. De fato, as ações afirmativas poderão beneficiar os negros que já se encontram em uma situação minimamente melhor do que a maioria das pessoas negras e pobres. Mas é preciso retomar o que foi dito com relação aos objetivos das ações afirmativas. Elas sozinhas não vão fazer com que todas as pessoas excluídas passem a estudar nas universidades, até porque isso é utópico e nem mesmo as políticas universalistas conseguiram o feito de haver vagas para atender a todas as pessoas.

Assim como somente uma elite branca estuda nas universidades (públicas, ao menos), também uma elite negra estudará nessas universidades. O fato importante é que haja pessoas negras nesses espaços, para iniciar um processo de mudança. Os brancos que ocupam esses espaços precisam conviver com negros, pois o negro possui o direito ao reconhecimento e a ter o seu estereótipo mudado, e o próprio ambiente universitário, por 
suas características, requer um espaço diverso, multicultural, representativo. Além disso, como já explicado no início deste capítulo, as ações afirmativas possuem diferentes eficácias e fundamentos, que passam pelas justiças compensatória e distributiva até a existência de negros (poucos no começo, e mais e mais ao longo do tempo) em espaços de poder e nos ambientes tradicionalmente ocupados por outros grupos.

5.3.8 As ações afirmativas são inconstitucionais, pois contrariam o princípio de que todos são iguais perante a lei

No capítulo sobre o princípio da igualdade, foi apresentada, de forma evidentemente resumida, a evolução dos diversos sentidos do conceito de igualdade. Ao final, ficou claro que, atualmente, uma das interpretações desse conceito diz respeito ao seu aspecto substancial, e não meramente formal.

A máxima "todos são iguais perante a lei" sem dúvida deve ser cumprida integralmente. Para que isso ocorra, no entanto, aqueles que se encontram em situações fáticas diferentes não podem ser tratados da mesma maneira, sob o risco de se perpetuar a distância entre as pessoas ou grupos diferentes, ainda que todos eles, em alguma medida, "caminhem para frente". Essa é uma das razões pelas quais as ações afirmativas não são inconstitucionais; elas apenas são uma das formas de concretizar o princípio da igualdade.

Além disso, existem alguns exemplos de ações afirmativas previstos na Constituição Federal, como aquelas destinadas às pessoas com deficiência. Dessa maneira, não há que se falar em inconstitucionalidade de uma figura já prevista no texto da Constituição.

5.3.9 As ações afirmativas para negros em universidades seriam humilhantes para os negros

Inicialmente, é importante ter clara a diferença da discriminação para uma política como a ação afirmativa. Naquela, há uma mensagem de desprezo pelo outro - o outro é inferior -, enquanto nesta a mensagem transmitida é de consideração e de respeito, para que 
a igualdade de fato seja mais rapidamente alcançada. Grupos que sofrem discriminação são vistos socialmente como não sujeitos a determinados direitos, como desiguais em dignidade. Por outro lado, grupos destinatários de ações afirmativas são vistos justamente como iguais em dignidade e direitos humanos.

Segundo Dworkin, é possível distinguir a ação afirmativa do uso maligno de raça. Existe um direito individual que as formas malignas de discriminação violam, mas que programas bem elaborados de ação afirmativa não o fazem. A defesa das ações afirmativas não expressa, direta ou indiretamente, preconceito contra cidadãos brancos (2005, p. 574$575)$.

As pessoas que eventualmente humilharem alguém admitido em uma universidade por meio de ações afirmativas claramente não conhecem o propósito e os fundamentos desse tipo de política, sendo necessário, então, um processo de educação e de conscientização a esse respeito.

\footnotetext{
Discriminar os negros no mercado de trabalho pelo fato deles terem estudado graças às cotas é simplesmente deslocar o eixo do preconceito e da discriminação presentes na sociedade e que existem sem cotas ou com cotas. (MUNANGA, 2002, p. 133)
}

Se, por outro lado, o sentimento de humilhação vier de uma pessoa negra, é certo que essa pessoa pode escolher se quer se declarar negra e assim ser destinatária da política de ação afirmativa. No entanto, o processo de educação e conscientização sobre as políticas também deve ser destinado aos próprios grupos vulneráveis, para que eles entendam os objetivos dessas medidas e vejam nelas mais uma possibilidade de concretizar um direito seu, e não um mero favor ou benefício. 


\title{
6 O NEGRO NO BRASIL: O QUE OS NÚMEROS REVELAM
}

Ainda persiste na cultura brasileira a ideia da democracia racial - pensamento difundido por diversos intelectuais na primeira metade do século $\mathrm{XX}$, entre os quais se destaca Gilberto Freyre. Essa teoria considera o mestiço o ponto de equilíbrio do país, e, o Brasil, o lugar da harmonia, do intercâmbio cultural e da tolerância. No entanto, por trás da ideia da mestiçagem, havia um projeto de branqueamento da população. Sua negritude desapareceria de geração em geração, até que o país tivesse feições similares às europeias, terra do homem branco, símbolo da ideia de progresso. Segundo Edward Telles,

\begin{abstract}
O branqueamento e a democracia racial, os dois pilares da ideologia racial do Brasil, estão profundamente enraizados numa crença de que a miscigenação é um fato histórico que torna o Brasil único. A ideologia do branqueamento via a miscigenação de forma negativa, enquanto a democracia racial a promovia como solução brasileira para o racismo. A ideologia do branqueamento tentou retificar o temor do século XIX, fundamentado 'cientificamente', de que tamanha miscigenação condenaria o Brasil ao subdesenvolvimento perpétuo. Em contrapartida, as elites brasileiras, com o reforço de uma pequena parcela da comunidade científica, decidiram que podiam eliminar a grande população de negros através de um processo de branqueamento que fazia uso da miscigenação, acompanhada de uma imigração européia maciça. $(2003 \text {, p. } 62)^{65}$
\end{abstract}

Dentro dessa ideia de branqueamento da população, Wedderbum explica que a integração do negro aconteceu mediante "um complexo sistema de cooptação baseado na mestiçagem biológica, vertical e unilateral do segmento racial subalternizado", e segue constatando que, com essa mestiçagem de mão única a população negra acabou por se afastar da sua identidade original, fato que favoreceu, ou facilitou, a dominação branca (2005, p. 326). É essa realidade que o autor denomina de democracia racial, o que, para ele, é "uma ordem pigmentocrática, responsável pela produção de preconceitos e desigualdades, que tem tudo de racial e nada de democrático" (2005, p. 326).

Hasenbalg afirma que o mito da democracia racial é reforçado pela ausência de conflitos abertos, pela inexistência de uma discriminação legal, pela presença de algumas pessoas negras entre as elites e por casamentos inter-raciais. Para ele, "os teóricos da 'miscigenação' parecem ter confundido mistura racial biológica com interação racial em

\footnotetext{
65 Não se pretende esgotar aqui a discussão sobre a democracia racial. Para um conhecimento mais aprofundado, sugere-se a leitura de Casa Grande \& Senzala, de Gilberto Freyre (1994), Preconceito de marca: as relações raciais em Itapetininga, de Oracy Nogueira (1998), Raças e classes sociais, de Octavio Ianni (1987), Negros em Florianópolis: relações sociais e econômicas, de Fernando Henrique Cardoso (2000), O negro no mundo dos brancos, de Florestan Fernandes (2007).
} 
um sentido sociológico" (2007, p. 237). Além disso, complementa citando Rout, para quem “... a ordenação hierárquica das pessoas em termos de sua proximidade com a brancura ajudou no desdém que as pessoas de cor mais escura demonstram por sua origem africana" e lembra expressões da língua portuguesa que comprovam isso, tais como "cabelo ruim" e "melhorar a raça", e fragmentação das identidades raciais quando a percepção social da raça ocorre de acordo com um continuum de tonalidades (2007, p. 238), como marrom-bombom, cor de café etc.

Complementam Paulo V. Baptista da Silva e Fúlvia Rosemberg que, após a abolição da escravidão no Brasil, as relações sociais entre brancos e negros foram marcadas por três processos principais: a) o país não adotou leis segregacionistas (como fizeram os Estados Unidos e a África do Sul), b) o país tampouco promoveu a integração do negro liberto à sociedade por meio de políticas específicas, fortalecendo, dessa forma, a exclusão do negro e a criação de uma pobreza majoritariamente negra, c) o país incentivou a imigração europeia, como parte de uma política de branqueamento da população (2008, p. 75).

Apesar de ainda estar arraigada essa ideia de que no Brasil não haveria discriminação racial em função da ampla mestiçagem, há parcela da população que hoje discorda dessa premissa, e até mesmo institutos de pesquisa reconhecidos, como o Ipea. $\mathrm{Na}$ introdução de um de seus estudos, os seus autores escrevem que

\begin{abstract}
A existência da discriminação contra negros no Brasil é hoje reconhecida como fato. Após extensa produção tanto qualitativa como quantitativa, é difícil negar os grandes diferenciais raciais observados em quase todos os campos da vida cotidiana. Negros nascem com peso inferior a brancos, têm maior probabilidade de morrer antes de completar um ano de idade, têm menor probabilidade de freqüentar uma creche e sofrem taxas de repetência mais altas na escola, o que os leva a abandonar os estudos com níveis educacionais inferiores aos dos brancos. Jovens negros morrem de forma violenta em maior número que jovens brancos e têm probabilidades menores de encontrar um emprego. Se encontram um emprego, recebem menos da metade do salário recebido pelos brancos, o que leva a que se aposentem mais tarde e com valores inferiores, quando o fazem. Ao longo de toda a vida, sofrem com o pior atendimento no sistema de saúde e terminam por viver menos e em maior pobreza que brancos. E isso não decorre apenas da situação de pobreza em que a população negra está majoritariamente inserida. As desigualdades raciais no Brasil são influenciadas de maneira determinante pela prática passada e presente da discriminação racial. (2007, p. 281)
\end{abstract}

Poucos são aqueles que se assumem racistas, apesar de haver um amplo reconhecimento da existência de discriminação racial, racismo e preconceito no país. 
De acordo com uma pesquisa realizada pelo Instituto Datafolha ${ }^{66}$, em 1995, 89\% dos entrevistados concordaram que os brancos são racistas, mas somente $10 \%$ dos entrevistados que não se declararam de cor preta admitiram portar, eles mesmos, essa característica. Em novembro de 2008, para contextualizar o feriado da consciência negra, o jornal Folha de São Paulo publicou um caderno especial com nova pesquisa realizada pelo mesmo Instituto ${ }^{67}$, e concluiu que, nos dias atuais, $3 \%$ dos entrevistados que não se declararam de cor preta possuem preconceito com relação aos negros, e $91 \%$ acreditam que os brancos possuem preconceito em relação aos negros.

Uma terceira pergunta feita aos entrevistados de 1995 e de 2008 foi se eles concordavam com algumas frases apresentadas pelo Instituto. A primeira foi "negro bom é negro de alma branca", e, em 1995, 45\% dos entrevistados concordaram com essa frase, sendo que em 2008 essa porcentagem caiu para 26\%. A segunda frase foi "as únicas coisas que os negros sabem fazer bem são música e esporte", e as porcentagens de entrevistados que concordaram foram 43\%, em 1995, e 20\%, em 2008. A terceira frase apresentada foi "negro, quando não faz besteira na entrada, faz na saída", e $24 \%$ dos entrevistados concordaram com ela em 1995, e 10\% em 2008. A última frase foi "se Deus fez raças diferentes é para que elas não se misturem", para qual houve $23 \%$ de respostas de concordância em 1995 e 9\% em 2008.

$\mathrm{O}$ mais interessante nessas respostas é que elas foram agrupadas também por escolaridade e idade. Percebe-se, nas respostas às quatro perguntas, que a porcentagem de concordância é tanto maior quanto maior a idade e quanto menor a escolaridade.

O caderno segue citando alguns dados do Instituto Brasileiro de Geografia e Estatística (IBGE) de 1995 e de 2007: em 1995, 67,5\% dos 10\% mais pobres do Brasil eram pretos e pardos, e esse valor subiu para 68,1\% em 2007. Em 1995, os pretos e pardos compunham somente 17,3\% dos $10 \%$ mais ricos, e em 2007 esse valor subiu para 21,9\%.

No ensino superior, o Datafolha apresentou dados também do IBGE que relatam haver, em 1995, 18\% de pretos e pardos nas universidades, contra $80 \%$ de brancos. Em 2007, o valor referente à presença dos pretos e pardos subiu para $31 \%$ e o valor referente à presença dos brancos nas universidades caiu para $67 \%$.

Em 1995, segue o Datafolha citando o IBGE, o rendimento médio mensal real do trabalho dos pretos e pardos era de $\mathrm{R} \$ 496$, contra $\mathrm{R} \$ 1.061$ dos brancos. Em 2007, o primeiro número foi para $\mathrm{R} \$ 563$ e o segundo para $\mathrm{R} \$ 1.050$.

\footnotetext{
${ }^{66}$ A pesquisa de 1995 contou com 5.081 pessoas entrevistadas em 121 cidades do país.

${ }^{67}$ A pesquisa de 2008 contou com 2.982 pessoas entrevistadas em 213 municípios.
} 
O Datafolha perguntou quem sofreria mais preconceito no Brasil aos entrevistados de 2008, e as respostas foram as seguintes: para 56\% são os pretos/negros, para $21 \%$ são os pobres, e o resto se divide em homossexuais (8\%), não sabe (6\%), deficientes físicos (3\%), outros $(3 \%)$, indígenas $(2 \%)$, mulheres $(1 \%)$, brancos $(1 \%)$ e idosos $(1 \%)$.

No texto de introdução do caderno, após a constatação de que o preconceito aberto é assumido por menos pessoas, mas a maioria dos entrevistados ainda considera a sociedade brasileira racista, os autores do especial escrevem que "alguns analistas enxergam nessa contradição um indício de que parte da queda no preconceito declarado seja resultado apenas de um racismo mais "velado"” (p. 2). Na página seguinte, há menção à historiadora Lilia Moritz Schwarcz, que conclui pela popularização do discurso politicamente correto, de 1995 para 2008, o que, ao menos em parte, pode ajudar a explicar a queda nas porcentagens (p. 3). Esse discurso corresponderia ao que outro historiador também citado por essa reportagem, Manolo Florentino, chama de pudor: “... estaremos mais uma vez frente à constatação de que nosso racismo é envergonhado, que, afora casos patológicos, o brasileiro só expressa seu preconceito racial através de carta anônima” (p. 3).

Considerando o exposto acima, pode-se concluir que o preconceito e a discriminação racial sempre foram e ainda são problemas que devem ser enfrentados a fim de que a sociedade brasileira possa de fato ser mais justa e democrática.

A discriminação e o preconceito racial, por não serem amplamente reconhecidos, parecem não existir e, portanto, aos olhos de boa parte da sociedade, não produzem efeitos. A desigualdade seria apenas social, e não racial, fruto somente de uma situação de pobreza generalizada. Dessa forma, o fato de a maioria dos excluídos ser negra seria fruto apenas do passado, fruto da escravidão de africanos e seus descendentes ao longo de quase quatro séculos.

Porém, a exclusão do negro da sociedade também decorre de um racismo velado, da vergonha de reconhecer os próprios preconceitos (o "pudor" mencionado anteriormente). Rita Laura Segato esclarece que no Brasil vigora o tipo de racismo chamado, por ela, de prático. Em suas próprias palavras, ele é "automático, irrefletido, naturalizado, culturalmente estabelecido e que não chega a ser reconhecido ou explicado". Segundo a autora, essa espécie de racismo é a que mais produz vítimas, e é a mais difícil de ser combatida, justamente por parecer invisível, por ser inominada (SEGATO, 20052006, p. 79). Para ser desconstruído, o racismo precisa se tornar visível. 
Não é sem causa, ou somente devido ao passado, que os negros ainda ocupam posições de inferioridade social (política e econômica) na nossa sociedade. Constata-se essa desvantagem, por exemplo, no pequeno número de estudantes negros que compõem o corpo discente dos cursos do ensino superior: Pesquisa Nacional por Amostra de Domicílios (PNAD) realizada em 2005 apontou que, dos brasileiros brancos com idade entre 18 e 24 anos, $51,8 \%$ frequentam ou frequentaram o ensino superior; já dos brasileiros pretos ou pardos na mesma faixa etária, o percentual é 19,3.

Verifica-se, por meio da observação de dados coletados por órgãos oficiais, como o IBGE, que, mesmo transcorrido mais de um século da abolição, os negros não exercem os seus direitos constitucionalmente garantidos em sua plenitude, por não possuírem as mesmas condições de educação e trabalho, acesso à saúde e à justiça que os brancos. Existe a chamada igualdade jurídica, mas não a igualdade de fato, ou mesmo a igualdade de condições.

Os pretos e pardos (negros) constituem, de acordo com a PNAD de 2005, um total de 88.328.296,7 em 181.000.608 de brasileiros, ou 48,8\% da população, sendo que os brancos correspondem a 50,5\%. Mais precisamente, os autodeclarados pretos correspondem a $6,3 \%$ e os autodeclarados pardos correspondem a $42,5 \%$.

Apesar de serem praticamente metade da população, os pretos e pardos constituem $73,5 \%$ dos $10 \%$ mais pobres do país, enquanto somente $11,6 \%$ do $1 \%$ mais ricos, segundo pesquisa realizada pelo IBGE também em 2005. Uma terceira pesquisa realizada pelo instituto, no mesmo ano, revelou a discrepância dos salários: brancos com 12 anos ou mais de estudo ganham, em média, R\$ 15 por hora; já negros com o mesmo tempo de estudo ganham em média $\mathrm{R} \$ 10,7$ por hora. Verificou-se ainda que os brancos possuem em média 8,6 anos de estudo, com um rendimento médio de 3,6 salários mínimos. Já os negros possuem em média 6,4 anos de estudo, com um rendimento médio de 1,9 salário mínimo.

Se as instituições sociais, o acesso a oportunidades e a realização de necessidades básicas fossem universais, todas as pessoas encontrar-se-iam em situação de igualdade. Bastaria, assim, a aplicação da igualdade formal, ou igualdade de tratamento. No entanto, é sabido que os negros não estão em situação de igualdade em relação aos brancos, devido ao passado histórico de escravidão e à vigente e presente discriminação, não somente por serem em sua maioria pobres, mas também por serem negros - a denominada dupla discriminação. Destarte, é importante que se pense em políticas para corrigir, ou ao menos atenuar, o mais breve possível, essa situação insustentável em um Estado que se diz democrático e de Direito, sob a vigência de uma constituição denominada "cidadã". Por 
isso, a importância da discussão sobre a implementação de ações afirmativas em universidades públicas. 


\section{A LEGISLAÇÃO DO RIO DE JANEIRO}

A Assembleia Legislativa do estado do Rio de Janeiro promulgou cinco leis que instituíram cotas em universidades estaduais.

A primeira lei data de 28 de dezembro 2000, e entrou em vigor em 2001. É a Lei n. 3254, que dispôs sobre os critérios de seleção e admissão de estudantes da rede pública estadual de ensino em universidades públicas estaduais e deu outras providências. Essa lei reservou $50 \%$ das vagas de todos os cursos das universidades públicas estaduais para alunos que cursaram integralmente os ensinos fundamental e médio em instituições da rede pública dos municípios e/ou do estado. A lei foi revogada pela 4151/2003.

A segunda lei é a n. 3708, de 9 de novembro de 2001, também revogada pela 4151/2003. Ela instituiu cota de até $40 \%$ para as populações negra e parda no acesso à Universidade do Estado do Rio de Janeiro (UERJ) e à Universidade Estadual do Norte Fluminense (UENF).

O Decreto 30.766/2002 regulamentou essa lei e determinou a inexistência de distinção entre pessoas negras e pardas e a autonomia das universidades na definição dos critérios mínimos de qualificação para o acesso às vagas reservadas aos alunos negros e pardos. Além disso, estipulou que deveria ser deduzido, da cota de $40 \%$, o percentual de candidatos selecionados, declarados negros ou pardos, já beneficiados pela Lei $\mathrm{n}$. $3524 / 2000$, e preenchidas as vagas restantes, dentro da cota de $40 \%$, com os demais candidatos declarados negros ou pardos selecionados, independentemente da origem escolar. Observou-se que a identificação do candidato como negro ou pardo é feita mediante autodeclaração facultativa, e que na hipótese de não preenchimento da cota de $40 \%$, as vagas restantes poderiam ser destinadas aos outros candidatos.

A terceira lei é a n. 4151 de 4 de setembro de 2003. Por meio dela foi instituída nova disciplina sobre o sistema de cotas para ingresso nas universidades públicas estaduais. Essa lei revogou as duas leis anteriores e estabeleceu cotas para ingresso nos cursos de graduação das universidades públicas do estado do Rio de Janeiro para estudantes carentes, oriundos da rede pública de ensino; negros; pessoas com deficiência; integrantes de minorais étnicas; e filhos de policiais civis e militares, bombeiros militares e inspetores de segurança e administração penitenciária, mortos ou incapacitados em razão 
do serviço (sendo esta última parte referente aos filhos, dada pela nova redação da Lei n. $\left.5074 / 2007^{68}\right)$.

Ficou determinado que nos cinco primeiros anos de vigência da lei o percentual mínimo de vagas reservadas para os estudantes carentes deveria ser $45 \%$, distribuído da seguinte forma: $20 \%$ para estudantes oriundos da rede pública de ensino; 20\% para negros; e $5 \%$ para os demais.

A lei também trouxe alguns conceitos importantes à luz, ao menos para fins de aplicação da reserva de vagas. A definição de estudante carente ficou a critério da universidade, que deveria levar em consideração o nível socioeconômico do candidato e definir os critérios para verificar essa condição, valendo-se de indicadores socioeconômicos oficiais. Dentro da gama de estudantes carentes, o primeiro grupo correspondeu aos candidatos que cursaram integralmente todas as séries do $2^{\circ}$ ciclo do ensino fundamental em escolas públicas do Brasil e todas as séries do ensino médio em escolas públicas municipais, estaduais ou federais localizadas no estado do Rio de Janeiro. No segundo grupo estavam os negros, que teriam que se autodeclarar como negros para poder concorrer às vagas reservadas. $\mathrm{O}$ mesmo valeu para as minorias étnicas, do terceiro grupo. Para os filhos de policiais, bombeiros e inspetores, foram exigidas a apresentação da certidão de óbito e a decisão administrativa que reconheceu a morte em razão do serviço. Também estavam presentes no terceiro grupo as pessoas com deficiência.

A lei previu que o candidato deveria optar em qual dos grupos de reserva de vagas iria concorrer. Na hipótese de haver vagas reservadas para um dos grupos não preenchidas, elas seriam ocupadas, prioritariamente, por candidatos dos outros dois grupos, de acordo com a ordem de classificação na seleção.

A lei também previu a existência de uma Comissão Permanente de Avaliação, que, dentre outras atividades, deveria analisar os resultados decorrentes da aplicação do sistema de cotas em sua respectiva universidade.

Recentemente, a Assembleia Legislativa aprovou outra lei para dispor sobre o novo sistema de cotas nas universidades estaduais do Rio de Janeiro. Isso foi necessário já que a Lei de 2003 estabeleceu um prazo de cinco anos para a sua revisão. ${ }^{69}$

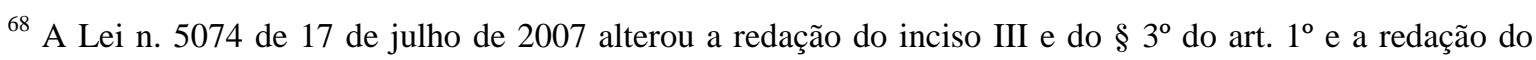
inciso III do art. $5^{\circ}$ da Lei n. 4151/2003, estendendo a reserva de vagas para filhos de policiais civis e militares, bombeiros militares e inspetores de segurança e administração penitenciária, mortos ou incapacitados em razão do serviço.

${ }^{69}$ É coerente com o conceito de ação afirmativa uma lei que propõe medidas de discriminação positiva também estabelecer um prazo para o seu próprio fim. Medidas assim justificam-se pela urgência de combater
} 
A Lei 5346, de 11 de dezembro de 2008, prorrogou por mais dez anos o sistema de cotas nas universidades estaduais do Rio de Janeiro. Manteve muito do que já estava previso na Lei de 2003, com exceção de alguns pontos.

No artigo $1^{\circ}$, aquele que contém os grupos beneficiários das cotas, foi retirada a expressão "integrantes de minorias étnicas" do inciso III e acrescentou-se um inciso que contém o termo "indígenas".

Os estudantes oriundos da rede pública deixaram de ser aqueles que cursaram o segundo ciclo do ensino fundamental e o ensino médio em escolas públicas localizadas no estado do Rio de Janeiro e passaram a ser os estudantes que cursaram o segundo ciclo do ensino fundamental e o ensino médio em escolas públicas localizadas em todo o território nacional.

Outra novidade dessa última lei é a previsão de que, caso persistam vagas reservadas ociosas, elas deverão ser preenchidas, obrigatoriamente, pelos candidatos que não optaram pelo sistema de cotas.

Além disso, foi determinada a criação, pelo Poder Executivo, de uma comissão responsável pela avaliação dos resultados do programa de ação afirmativa, no prazo de um ano anterior ao fim dos dez anos de vigência da lei.

Com relação à proporção na reserva de vagas, a nova lei trouxe pequenas mudanças: ficou estabelecida uma reserva de $20 \%$ das vagas para negros e indígenas (na Lei de 2003 a reserva era de $20 \%$ somente para negros), 20\% das vagas para estudantes oriundos da rede pública de ensino (igual à Lei de 2003, sendo que a partir de agora não há mais a restrição de escolas localizadas no estado do Rio de Janeiro), e 5\% das vagas para pessoas com deficiência e filhos de policiais civis, militares, bombeiros militares e de inspetores de segurança e administração penitenciária, mortos ou incapacitados em razão do serviço (a nova previsão excluiu dos $5 \%$ os integrantes de minorias étnicas).

Por fim, a Lei de 2008 obriga o estado do Rio de Janeiro ao pagamento de bolsaauxílio aos estudantes carentes durante todo o período de curso universitário.

Essa lei de 2008 foi questionada no Tribunal de Justiça do estado do Rio de Janeiro por meio de uma ação direta de inconstitucionalidade (2009.007.00009) proposta pelo deputado estadual (RJ) Flavio Bolsonaro. Em 25 maio de 2009, o Órgão Especial do Tribunal, tendo como relator o desembargador José Carlos S. Murta Ribeiro, concedeu

uma situação de desigualdade. O tratamento desigual visa ao alcance de uma situação de igualdade de fato. Se esse tratamento for exitoso, ele não mais será necessário, daí o seu caráter temporário. 
liminar, por maioria dos votos, suspendendo os efeitos da lei até o julgamento do mérito. A ementa está transcrita abaixo:

REPRESENTAÇÃO POR INCONSTITUCINALIDADE DA LEI 5346/2008 APRECIAÇÃO DE LIMINAR NO SENTIDO DE SUSPENDER A EFICÁCIA DESTE DIPLOMA LEGAL QUE ESTABELECE NOVO SISTEMA DE COTAS

PARA INGRESSO NAS UNIVERSIDADES ESTADUAIS - PRESENÇA DO FUMUS BONI IURIS ANTE AOS ARTIGOS $9^{\circ}, \S 1^{\circ}$ DA CONSTITUIÇÃO ESTADUAL E ARTIGOS $3^{\circ}$, IV E $5^{\circ}$ DA CONSTITUIÇÃO FEDERAL IGUALMENTE PRESENTE O PERCICULUM IN MORA ANTE A PROXIMIDADE DO VESTIBULAR E ANTERIORES REVOGAÇÕES DAS LEIS ESTADUAIS $\mathrm{N}^{\circ} 3.534 / 2000$ E $\mathrm{N}^{\circ} 3.708 / 2001$ - PRECEDENTE JURISPRUDENCIAL NESTE TRIBUNAL ESTADUAL E NO TRIBUNAL REGIONAL FEDERAL - LIMINAR QUE SE CONCEDE PARA SUSPENDER ATÉ A DECISÃO FINAL DE MÉRITO A EFICÁCIA DA LEI ESTADUAL N ${ }^{\circ}$ 5.346/2008 ORA IMPUGNADA. Presentes na hipótese os pressupostos legais das medidas cautelares se, como demonstrado nos autos, ocorre plausibilidade da tese exposta, irreparabilidade e insuportabilidade dos danos emergentes do próprio ato impugnado com a realização do certame do Vestibular 2009. As ações afirmativas, assim denominadas para a inclusão dos menos favorecidos, data vênia, não podem ser discriminatórias ao reverso, contrariando expressa disposição da Constituição Estadual em seu artigo $9^{\circ}$, $\S 1^{\circ}$, que estatui, verbis: "Ninguém será discriminado, prejudicado ou privilegiado em razão de nascimento, idade, etnia, raça, cor, sexo, estado civil, trabalho rural ou urbano, religião, convicções políticas ou filosóficas, deficiência física ou mental, por ter cumprido pena nem por qualquer particularidade ou condição." Esta a justa posição da hipótese sub examinem. Por igual, testilha a lei estadual impugnada com a Constituição Federal no seu artigo fundamental das garantias individuais: Artigo $5^{\circ}$, caput da Constituição Cidadã de 1988, verbis “Todos são iguais perante a lei, sem distinção de qualquer natureza, garantindose aos brasileiros e aos estrangeiros residentes no País a inviolabilidade do direito à vida, à liberdade, à igualdade, e à propriedade, nos termos seguintes: ... omissis." A contradição é manifesta quando se tem Lei Ordinária discriminatória pela Etnia - Negros e Indígenas —, pela cor — pardos —; convicções filosóficas; e, bem assim, quando ocorre qualquer particularidade ou condição - alunos da rede pública de ensino, pessoas portadoras de deficiência, nos termos da legislação em vigor, filhos de policiais civis e militares; bombeiros militares e inspetores de segurança e administração penitenciária, mortos ou incapacitados em razão de serviço -, o que é expressamente vedado pela Carta Magna, também no seu artigo $3^{\circ}$, inciso IV: "promover o bem de todos, sem preconceitos de origem, raça, sexo, cor, idade e quaisquer outras formas de discriminação". Certo, outrossim, que não é o regime de cotas a única ação positiva includente e nem a melhor. In Casu, vulnerase de rijo o princípio da igualdade de todos perante a lei e, data venia de doutas opiniões em contrário por ventura existentes, pretende-se prática afirmativa includente nas Universidades Estaduais, que como é do conhecimento de todos é o ponto culminante da pirâmide da Educação no Brasil. Em realidade, tais políticas afirmativas deveriam ter lugar no ensino fundamental e médio, reservando-se às Universidades o critério do mérito. Porque então não aplicar na espécie outras práticas includentes como, por exemplo, o Sistema de Bolsas de Estudos? A Lei impugnada, como posta, cria na verdade, numa proporção de $45 \%$ das vagas nas referidas universidades, privilégios não só para os Afro-descendentes e Índios - aqui numa direta relação com a Etnia, criando-se um "apartheid" até então inexistente no nosso País -, mas, também, para alunos provenientes da rede pública de ensino; pessoas portadoras de deficiência; e, filhos de policiais civis e militares, bombeiros militares e inspetores de segurança da Administração Penitenciária, nesta parte, contrariando de forma cabal e inafastável a parte final do $\S 1^{\circ}$ do 


\begin{abstract}
Artigo $9^{\circ}$ da Constituição Estadual e o inciso IV do artigo $3^{\mathrm{a}}$ da Constituição Federal. Em sede do exame liminar só estes argumentos são suficientes para tornarem presentes os pressupostos legais das medidas de urgência: a plausibilidade da tese exposta, o fumus boni iuris, bem como, a irreparablidade e a insuportabilidade dos danos emergentes, o periculum in mora, isto, face a proximidade do certame vestibular. Precedentes jurisprudenciais na Argüição de Inconstitucionalidade Incidenter Tantum $N^{\circ} 15 / 2009$ e no Exame da Liminar do Agravo 2008.02.01.012162-1 no Mandado de Segurança nº 2008.50.01.0073055. Liminar, pois, que se defere.
\end{abstract}

No dia 18 de novembro de 2009, o Órgão Especial julgou o mérito da ação e declarou que a Lei 5346/2008 é constitucional ${ }^{70}$. O relator da ação foi o desembargador Sergio Cavalieri, que foi acompanhado em sua posição pela maioria dos desembargadores. Decidiu-se que a lei não fere o princípio da igualdade, pois as minorias e os hipossuficientes precisam de um tratamento diferente, sob pena de tornar o princípio da isonomia uma fantasia. Além disso, o relator defendeu que as ações afirmativas e a melhoria do ensino não são medidas antagônicas e que uma afirmação de que a política de cotas fomentaria a separação racial é simplista.

Essa ação não foi a primeira proposta no Judiciário a questionar as cotas. A Confederação Nacional dos Estabelecimentos de Ensino (COFENEN) ajuizou uma ação direta de inconstitucionalidade no Supremo Tribunal Federal, em 19 de março de 2003, questionando a constitucionalidade das Leis n. 3254/2000, n. 3708/2001 e n. 4061/2003 (esta última reserva $10 \%$ das vagas das universidades públicas do estado do Rio de Janeiro para pessoas com deficiência). A ADIN 2858 foi extinta no dia 23 de setembro de 2003, em razão da revogação pela Lei n. 4151/2003 das três leis questionadas.

Outra ação direta de inconstitucionalidade também foi ajuizada contra o estado do Rio de Janeiro pela mesma Confederação Nacional dos Estabelecimentos de Ensino, em 3 de maio de 2004. É a ADIN 3197, que atualmente aguarda julgamento no Supremo Tribunal Federal, e que questiona a constitucionalidade da Lei n. 4151/2003 ${ }^{71}$. Em linhas gerais, essa ação contesta a constitucionalidade da Lei 4151 por seis motivos.

Em primeiro lugar, a Lei 4151/2003 teria criado privilégios para os grupos destinatários das cotas, em detrimento dos que foram dela excluídos, como os alunos que

\footnotetext{
${ }^{70}$ Até a conclusão desta dissertação a íntegra do acórdão não estava disponível na página do Tribunal, sendo que as informações aqui apresentadas foram colhidas do texto elaborado pela assessoria de imprensa do próprio Tribunal, disponibilizado na página eletrônica:

http://srv85.tjrj.jus.br/publicador/exibirnoticia.do?acao=exibirnoticia\&ultimasNoticias=17478\&classeNoticia $=2 \& v=2$. Acesso em: 03.01.2010.

${ }^{71}$ Assim como aconteceu com a ADIN 2858, é possível que a ADIN 3197 seja extinta sem julgamento do mérito por perda de objeto, visto que a Lei 4151/2003 foi revogada pela 5346/2008. O pedido já foi feito pela Procuradoria Geral da República e pela Procuradoria do Estado do Rio de Janeiro nos autos do processo.
} 
estudaram em colégios particulares, os candidatos brancos pobres, e os pardos (já que a Lei falaria especificamente em negros).

O segundo motivo seria que a Lei, por ser estadual, padeceria de um vício formal, pois somente a União teria a competência privativa para dispor sobre bases e diretrizes nacionais para a educação, de acordo com o art. 22, inciso XXVI da Constituição Federal.

Em terceiro lugar é alegado que a Lei ofenderia o caput do art. $5^{\circ}$ da Constituição Federal, que estabelece o princípio da igualdade e veda distinções de qualquer natureza. Alega-se na ADIN que o legislador estadual do estado do Rio de Janeiro teria criado uma distinção arbitrária em favor dos concorrentes ao vestibular que estudaram em escolas de ensino médio localizadas no estado do Rio de Janeiro, em detrimento daqueles que estudaram em escolas em outros estados. Além disso, o legislador também teria criado uma distinção arbitrária com base na cor e na etnia dos concorrentes ao vestibular, além de privilegiar as pessoas com deficiência. Para os autores da ação, somente a Constituição Federal poderia estabelecer exceções ao princípio da isonomia e da vedação de discriminações.

A Lei também ofenderia o princípio da meritocracia, previsto nos artigos 206, inciso I, e 208, inciso V da Constituição Federal. Alegam os autores da ação que o mérito seria a única maneira de garantir a igualdade no acesso ao ensino e que, no caso da legislação questionada, o mérito teria sido relativizado, pois nem sempre os candidatos com as melhores notas seriam os ingressantes nas universidades estaduais.

Em quinto lugar, a Lei ofenderia o art. 19, inciso III da Constituição Federal, ao criar preferência pelos habitantes do estado do Rio de Janeiro. Esse artigo veda à União, aos Estados, ao Distrito Federal e aos Municípios criar distinções entre brasileiros ou preferências entre si. Os autores da ADIN alegam que esse artigo teria sido violado porque "o legislador fluminense privilegiou seu próprio Estado", ao excluir do grupo destinatário das cotas aqueles que estudaram em outros estados que não o do Rio de Janeiro. ${ }^{72}$

Por fim, a Lei ofenderia o princípio da proporcionalidade, pois ela seria inadequada, desnecessária e desproporcional. O percentual total de $45 \%$ seria muito alto por reservar quase metade das vagas, sendo que cotas deveriam, na opinião dos autores da ação, ser sempre a exceção. Já o percentual de $20 \%$ reservados aos autodeclarados negros também seria demasiado alto, pois segundo dados do IBGE somente haveria $6,1 \%$ de

72 Esse argumento é parcialmente citado no início da ADIN, quando se fala na violação ao princípio da igualdade, e aparece novamente depois, especificamente quando se fala na violação ao art. 19, III, da Constituição Federal. 
negros na população brasileira. Por fim, alegam que cotas constituem uma medida muito danosa aos direitos dos concorrentes que delas não se beneficiam, e argumentam que existem outros meios menos gravosos para promover o acesso de estudantes de grupos minoritários à universidade, como os cursinhos preparatórios.

A organização não-governamental Conectas Direitos Humanos apresentou uma manifestação nos autos dessa ação, na qualidade de amicus curiae. Como a ADIN ainda não foi julgada, é interessante trazer ao menos os principais argumentos apresentados por essa organização, que se contrapõem à defesa da inconstitucionalidade feita pela CONFENEN.

Preliminarmente, a Conectas contesta a legitimidade da CONFENEN para propor uma ação direta de inconstitucionalidade, já que essa Confederação representa entidades privadas de ensino, e a Lei 4151 dispõe sobre as universidades públicas do estado do Rio de Janeiro. Também apresenta dados que mostram como a população negra e parda é subrepresentada na educação e nas esferas de poder (já que a educação é um dos principais meios de ascensão social), bem como é sub-remunerada em relação à população branca.

Outro argumento utilizado combate a ideia de que a meritocracia significa a nãodiscriminação ou a igualdade, pois somente aqueles que tiveram uma educação sofisticada e cara conseguem passar no vestibular, ou ao menos nos cursos mais concorridos. $\mathrm{O}$ vestibular teria, assim, se tornado um mecanismo de discriminação involuntária, ou um mecanismo de perpetuação de uma discriminação. A organização escreve que:

\footnotetext{
O que reivindica a qualidade de ser meritocrático, é na realidade um meio que privilegia os que acumulam conhecimento, o que não está necessariamente associado com o mérito individual, mas sobretudo com os meios que foram colocados à disposição de cada candidato. (p. 15)
}

A manifestação segue com o conceito e os objetivos das ações afirmativas, lembrando o art. $1^{\circ}, 4$, da Convenção Internacional sobre a Eliminação de todas as Formas de Discriminação Racial, das Nações Unidas, ratificada pelo Brasil em 1968, e dos pontos 140 e 148 do Plano Nacional de Direitos Humanos.

Alerta, também, para os princípios constitucionais a serem seguidos pela universidade, quais sejam, o ensino, a pesquisa e a extensão (art. 207), sendo que a transmissão de conhecimento tradicional, como a nossa sociedade conhece e enaltece, corresponderia a apenas um dos pilares do tripé universidade: o ensino.

Também aduz a Conectas que o art. 205 da Constituição prevê que a educação, de uma maneira geral, visa ao pleno desenvolvimento da pessoa, seu preparo para o exercício 
da cidadania e sua qualificação para o trabalho. Esse artigo casa com o artigo 207, pois, novamente, não é suficiente a transmissão de conhecimento para contemplar os três objetivos enumerados no art. 205, todos eles possuindo o mesmo status hierárquico. Muito mais é necessário, ao menos para o pleno desenvolvimento da pessoa e para o preparo da cidadania.

A organização segue indagando quais critérios seriam justos para que todos os objetivos constitucionais da universidade fossem alcançados. E responde que:

\footnotetext{
Neste sentido, os critérios escolhidos pelo legislador do Estado do Rio de Janeiro, parecem ser absolutamente legítimos, pois têm um nexo lógico de causalidade com as finalidade [sic] do sistema universitário. Ao escolher a raça, a origem escolar e a deficiência para, junto com o acumulo de conhecimento, formarem os critérios de seleção daqueles que poderão freqüentar a universidade pública, a lei favorece a realização não apenas dos objetivos primários, como daqueles mais amplos, que foram depositados nos ombros das universidades. (p. 34-35)
}

Por fim, conclui que o estado do Rio de Janeiro possui competência para legislar da forma que fez, pois o art. 22, inciso XXIV, da Constituição deu à União a competência privativa para legislar sobre as diretrizes e bases da educação nacional, mas o art. 24, IX deu também aos Estados a competência para legislar sobre educação. Não haveria conflito de concorrência, pois a União já teria criado a Lei de Diretrizes e Bases da Educação Nacional (LDB), a qual conferiu aos Estados a possibilidade de organizar seus sistemas de ensino.

Feito esse breve apanhado dos principais argumentos constantes na ADIN $3197 \mathrm{e}$ na manifestação da Conectas Direitos Humanos, é importante ressaltar que não se pretende, aqui, avaliar a qualidade de cada uma das leis estaduais do Rio de Janeiro, tampouco sua redação ou mesmo sua eficácia. Para isso seria necessário um estudo bastante amplo somente sobre as cotas nas universidades públicas estaduais do Rio de Janeiro, a maneira como elas foram implementadas, como estão os alunos que entraram por meio das vagas reservadas, e até mesmo um estudo em um futuro próximo (ou não tão próximo) para avaliar os resultados mais mediatos da política pública afirmativa. $\mathrm{O}$ objetivo do apanhado normativo e da ação no Supremo Tribunal Federal foi o de simplesmente apresentar as bases para a análise dos julgados coletados na página eletrônica do Tribunal de Justiça do estado do Rio de Janeiro.

Pode-se afirmar aqui, no entanto, que as leis já revogadas e a lei em vigor são tentativas de promover a justiça, por meio da implantação de medidas urgentes de 
reconhecimento e redistribuição. Algo que é muito interessante observar é a evolução dessas leis estaduais. Como já explicado anteriormente nesta dissertação, as ações afirmativas são legítimas e constitucionais, mas os modelos podem variar, e alguns deles podem ser falhos. Isso não quer dizer, no entanto, que a eventual ineficácia de um determinado modelo tenha que invalidar todo o fundamento da ação afirmativa. Pelo contrário. Assim como aconteceu no estado do Rio de Janeiro, no qual, desde 2001, já houve cinco leis promulgadas, é importante que qualquer espécie de política afirmativa seja sempre revista, reavaliada e melhorada. Até que um dia, espera-se, elas não sejam mais necessárias, pois, em conjunto com outras medidas, conseguiram produzir os efeitos desejados. 


\section{JULGADOS DO TRIBUNAL DE JUSTIÇA DO RIO DE JANEIRO}

Neste capítulo serão apresentados os dados referentes aos julgados encontrados nas buscas realizadas na página eletrônica do Tribunal de Justiça do estado do Rio de Janeiro, segundo a metodologia definida no capítulo 3.

Para iniciar a análise, todos os cento e oito julgados encontrados foram tabulados em uma planilha de Excel, com o preenchimento das seguintes categorias:

- Palavra de busca: para identificar de que forma o julgado foi encontrado.

- Tipo de recurso ${ }^{73}$ : ou seja, se foi uma apelação, um agravo de instrumento, uma representação por inconstitucionalidade etc.

- Julgado: preenchimento do número do julgado.

- Ano de julgamento

- Câmara

- Relator

- Decisão Unânime: nessa categoria, o espaço foi marcado com um "X" quando a decisão foi unânime.

- Autor

- Réu

- Lei questionada: nessa categoria, foram criadas três subcategorias, de acordo com o escopo desta pesquisa, quais sejam, Lei 3254/00, 3708/01 e 4151/03. Mais de uma subcategoria pôde ser marcada ao mesmo tempo, já que um mesmo julgado pode ter discutido mais de uma lei (exemplo: um candidato que não passou no vestibular ajuizou uma ação e questionou a constitucionalidade das Leis 3254/00 e 3708/01).

- Questionamento: nessa categoria, também foram criadas três subcategorias, quais sejam, rede pública (em consonância com as Leis 3254/00 e 4151/03), raça (em consonância com as Leis 3708/01 e 4151/03) e carência (em consonância com a Lei 4151/03). Nesse item também mais de uma subcategoria pôde ser marcada ao mesmo tempo (exemplo: um candidato que não passou no vestibular ajuizou uma ação e questionou os critérios de estudo na rede pública e de ser carente, fixados na Lei 4151/03).

\footnotetext{
${ }^{73}$ Ainda que a palavra "recurso" não seja o termo jurídico mais apropriado para todas as subcategorias, essa palavra foi escolhida apenas para fins de tabulação e uniformização.
} 
- Sentença: a partir da leitura do julgado de segunda instância, o que decidiu o juiz, na sentença, em primeira instância, e qual foi a tese do candidato em sua defesa ou em sua acusação, em linhas gerais (exemplo: sentença indeferiu pedido de liminar para candidata se matricular, porque ela não teria se classificado mesmo sem a lei de cotas. Candidata recorreu, sob o argumento de que leis ferem isonomia, razoabilidade e proporcionalidade: dificuldade de dizer quem é negro, alunos da rede privada têm rendas muito diferentes entre si).

- Acórdão: resumo do teor da decisão no Tribunal (exemplo: relator discorre sobre as ações afirmativas, sobre princípios, apresenta números dos negros e pobres. Reconhece a legitimidade das ações afirmativas e das leis. Fala do papel do Judiciário. Lembra que entre os pobres os negros são mais excluídos. Revoga a liminar e dá provimento ao recurso).

Com a planilha preenchida e com a utilização dos recursos do Excel, iniciaram-se as contagens e os cruzamentos entre as categorias.

\subsection{Tipo de recurso}

O gráfico abaixo ilustra os tipos de recursos que apareceram na busca realizada e que foram analisados, sendo o total de cento e oito.

Tipo de recurso

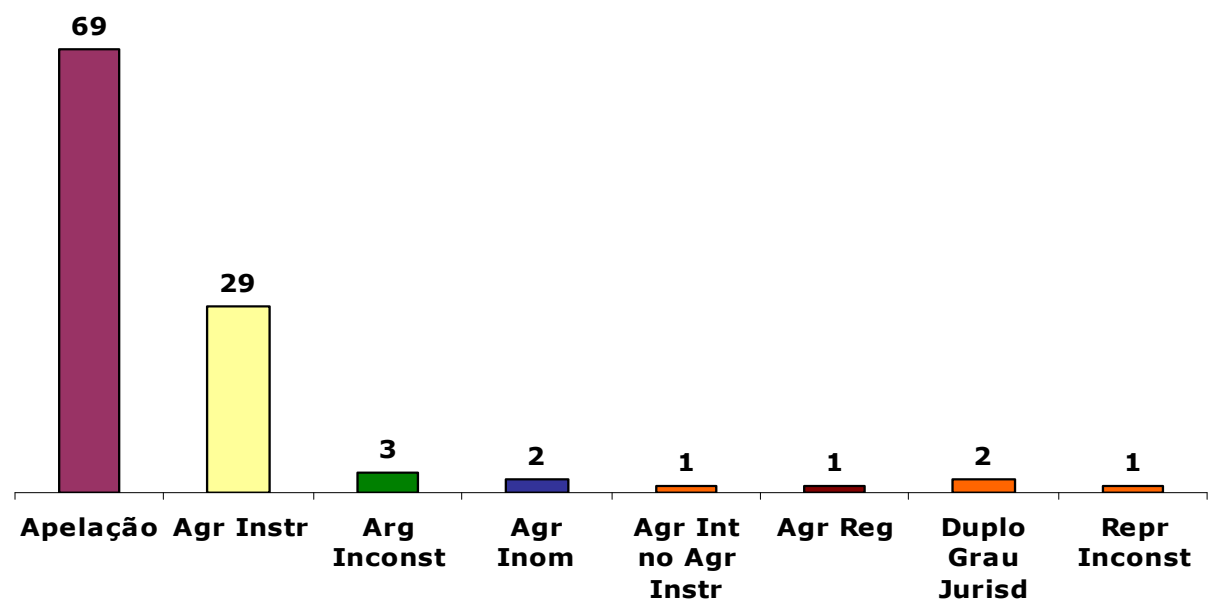




\subsection{Ano de julgamento}

Ainda que o recorte temporal da pesquisa tenha sido de 2001 a 2008, percebe-se, pelo gráfico abaixo, que os julgamentos relativos à primeira lei que instituiu um sistema de cotas - a Lei 3254/00 - só começaram a aparecer em 2003. É curioso notar que no ano de 2008 só houve três julgamentos, todos eles referentes à Lei 4151/2003, como se verá mais adiante. Uma explicação para isso pode ser o fato de gradualmente haver menos casos a serem julgados, pois talvez as pessoas estejam se conformando com a referida lei. Ou talvez os candidatos estejam desistindo de entrar com ação, pois não estão ganhando em segunda instância. Mas também pode ser o fato da demora nos julgamentos nesse ano. As hipóteses são algumas, e só poderão ser respondidas com uma nova pesquisa em outro momento.

Números de julgados por ano

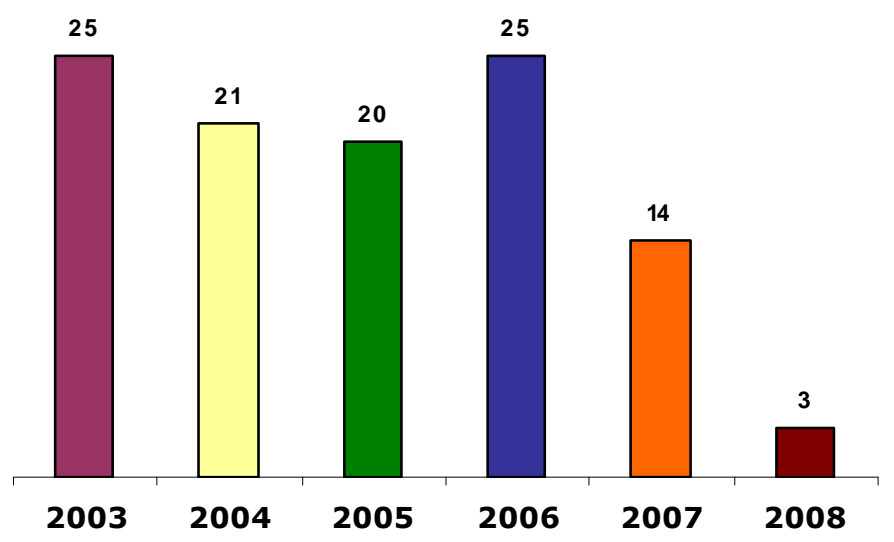

\subsection{Câmara}

Os casos coletados foram julgados na primeira até a vigésima câmara, com exceção da décima nona, e no órgão especial do Tribunal de Justiça. 


\subsection{Relator}

Foram sessenta e nove diferentes desembargadores ou desembargadoras que relataram os cento e oito casos analisados.

\subsection{Decisão Unânime}

O gráfico abaixo mostra que, em cento e oito julgamentos, a maioria foi de decisões colegiadas, sendo que todas elas foram unânimes, ou seja, os três desembargadores votaram no mesmo sentido. As decisões monocráticas se referem a dois agravos de instrumento (200300205825 e 200700211039 ), dos quais a Universidade do Estado do Rio de Janeiro (UERJ) e a Universidade Estadual do Norte Fluminense (UENF) recorreram, respectivamente.

No primeiro caso, o candidato que não concorreu pelo sistema de cotas teria conseguido liminar para se matricular, em função de a sua nota ter sido maior que a nota de candidatos que foram admitidos. A UERJ recorreu e perdeu, pois se considerou, na decisão, que a Lei 3708/01 feria o princípio da isonomia e que o critério racial não poderia determinar a ocupação das vagas nas universidades do estado em detrimento do aproveitamento escolar.

No segundo caso, a UENF agravou, pois o candidato que concorreu pelo sistema de cotas não teria estudado na rede pública no estado do Rio de Janeiro. A universidade ganhou, pois foi considerado que o Poder Judiciário não pode valorar uma lei como injusta.

\section{Tipo de decisão}

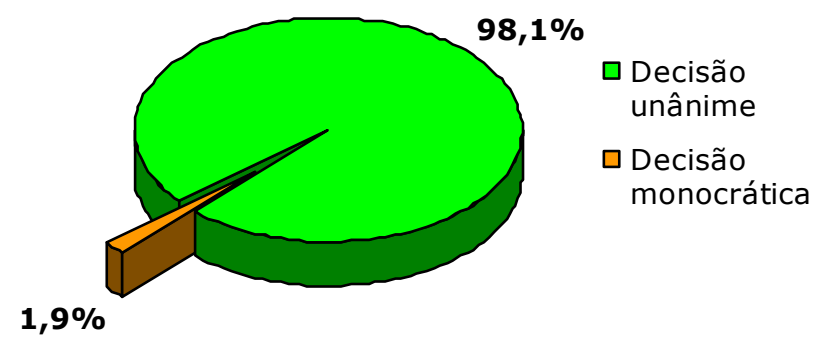




\subsection{Autor}

Os candidatos aparecem significativamente mais como autores dos recursos do que as universidades, conforme se vê nos dois gráficos abaixo. O primeiro mostra uma divisão simplificada. Já o segundo detalha quem são as universidades e quem são os candidatos.
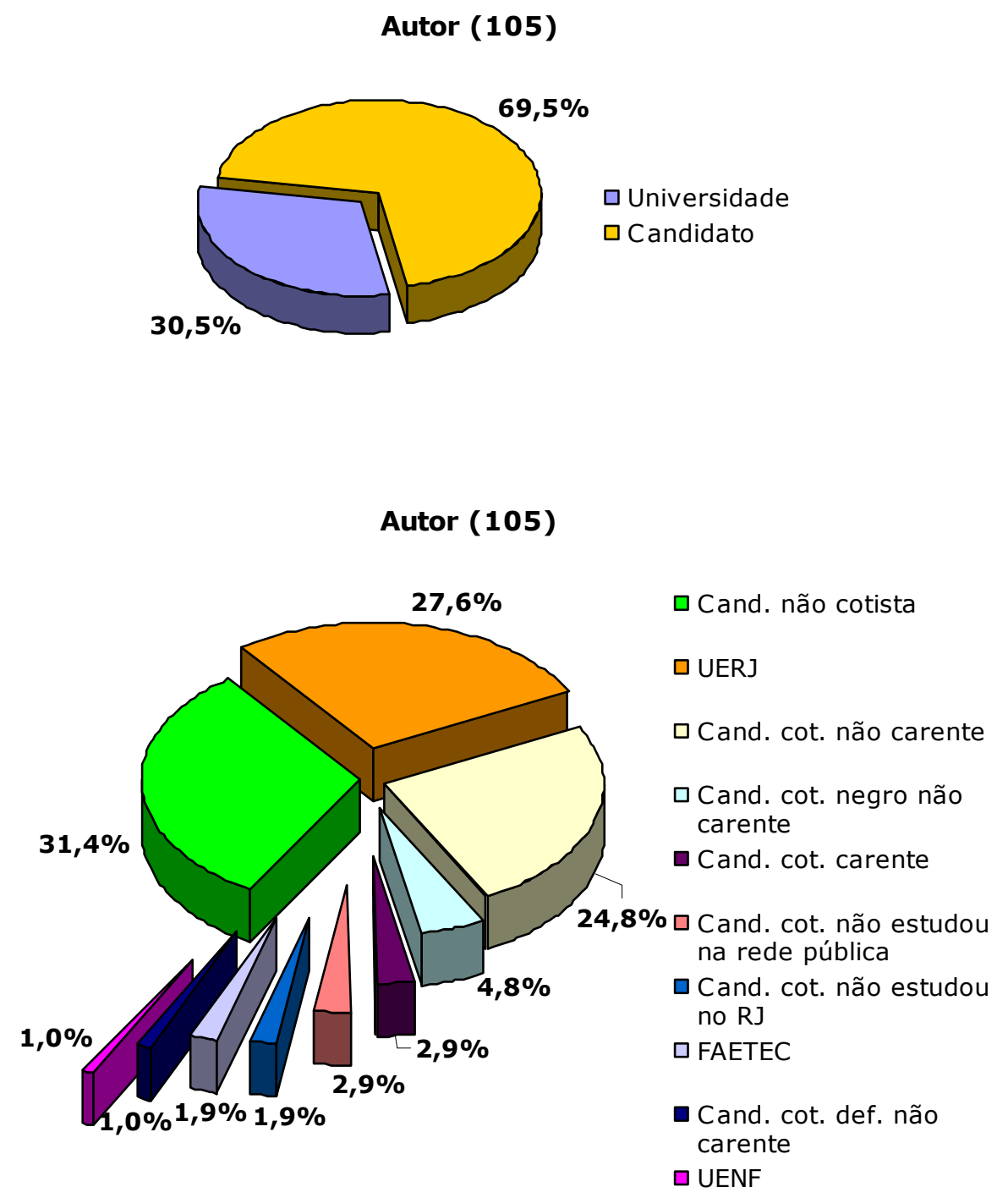

O gráfico acima pode ser ainda mais detalhado, dividindo-se os autores em universidades e em candidatos: 

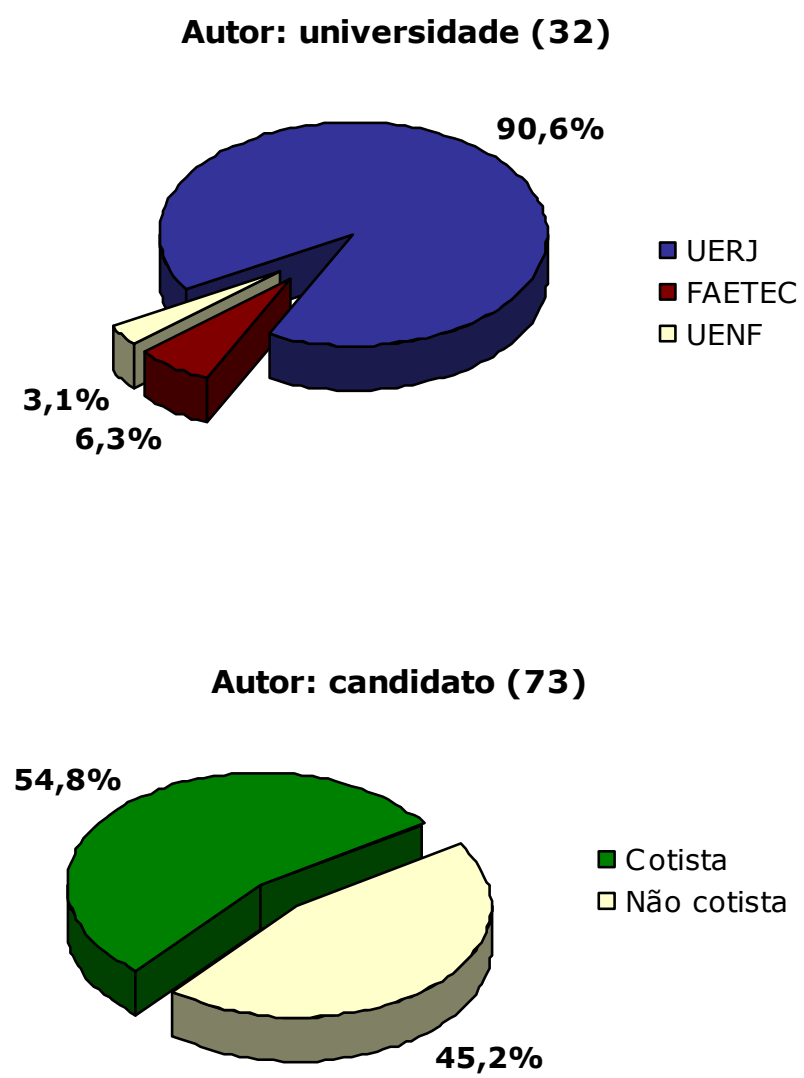

Realmente tanto candidatos que concorreram ao vestibular pelo sistema de cotas (por uma das três leis estudadas) quanto candidatos que concorreram sem ser pelo sistema de cotas entraram com ações na Justiça, para ter o seu interesse satisfeito. O número é bastante próximo, mas é curioso que há mais candidatos cotistas que recorreram. Talvez isso se deva ao fato de os cotistas perderem mais em primeira instância do que os não cotistas, ou talvez porque, assumindo que a proporção se mantenha entre os autores candidatos em primeira instância, os cotistas tenham procurado o Judiciário mais do que não cotistas. Os motivos para esses candidatos diferem bastante. Em regra, os não cotistas entraram com uma ação, pois não foram admitidos no vestibular e, por isso, questionam as leis de cotas. Já os candidatos cotistas têm motivos mais variados, como mostra o gráfico seguinte. 


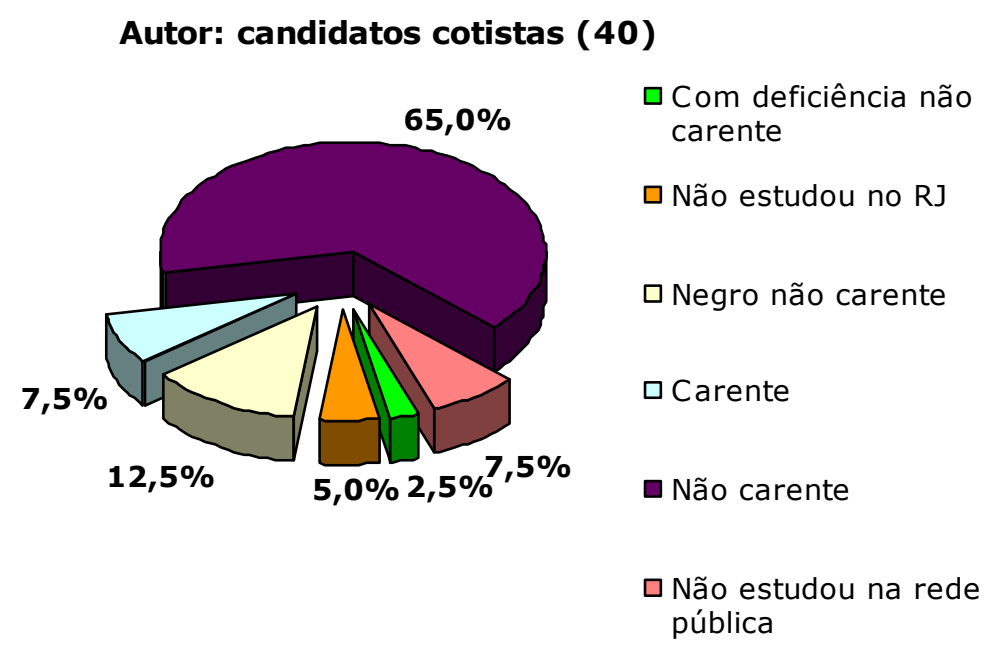

Dos candidatos cotistas (quarenta no total), há uma pessoa com deficiência que não comprovou ser carente, há dois que não estudaram integralmente no estado do Rio de Janeiro, há cinco negros que não comprovaram carência, há três que conseguiram comprovar serem carentes nos autos do processo (e, portanto, foram admitidos pela universidade ao final), há vinte e seis que não conseguiram comprovar serem carentes (não se sabe se são negros, se estudaram na rede pública ou se possuem deficiência), e há três que não estudaram na rede pública integralmente.

\subsection{Réu}

Se os candidatos aparecem mais como autores do que as universidades, nada mais lógico que as universidades apareçam mais como rés. O primeiro gráfico mostra uma divisão simplificada. Já o segundo detalha quem são as universidades e quem são os candidatos. 


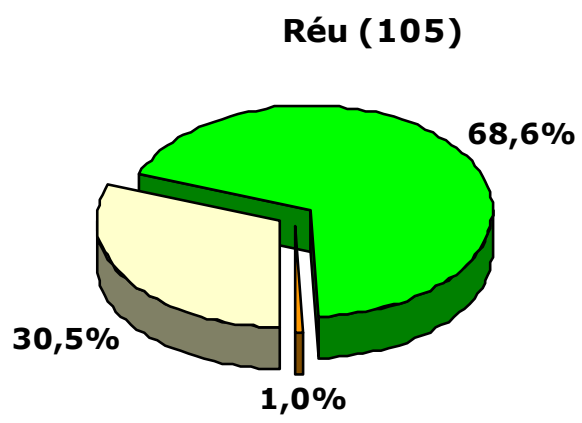

$\square$ Universidade

$\square$ Estado do RJ

$\square$ Candidato

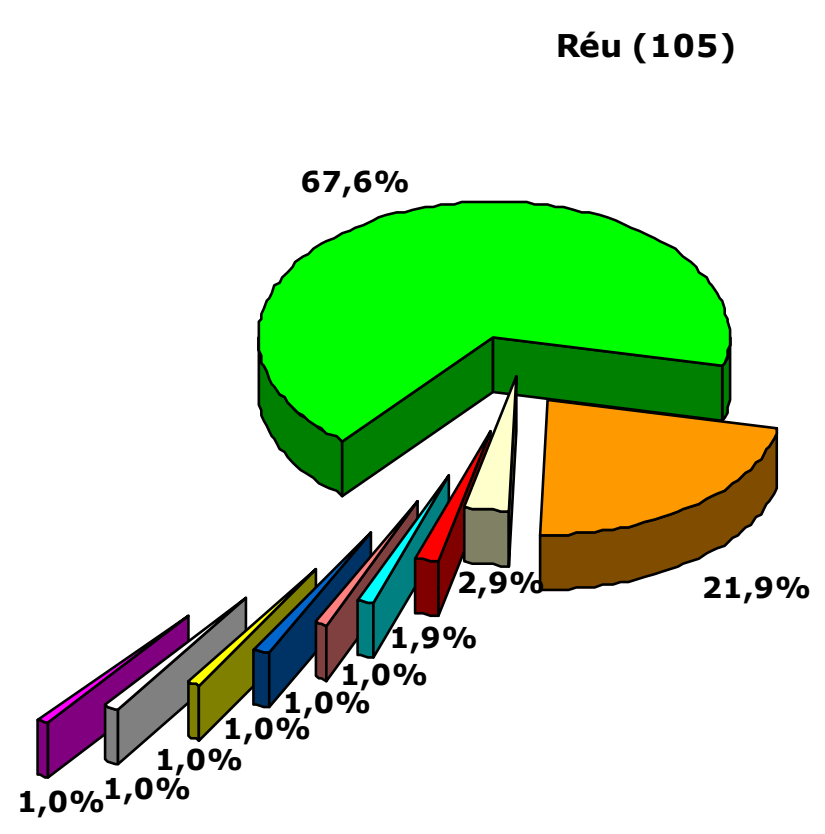

口 UERJ

$\square$ Cand. não cotista

$\square$ Cand. cot. não estudou no RJ

- Cand. cot. não estudou na rede pública

$\square$ UENF

$\square$ Estado do RJ

$\square$ Cand. cot. negro não carente

$\square$ Cand. cot. carente

$\square$ Cand. não cotista negro

๑ Cand. cot. não carente

O gráfico acima pode ser ainda mais detalhado, dividindo-se os réus em universidades e candidatos. No caso dos réus universidades, que totalizam setenta e dois, $99 \%$ corresponde à Universidade Estadual do Rio de Janeiro e $1 \%$ corresponde à Universidade Estadual do Norte Fluminense. Já no caso dos réus candidatos, temos a seguinte divisão: 


\section{Réu: Candidato (32)}

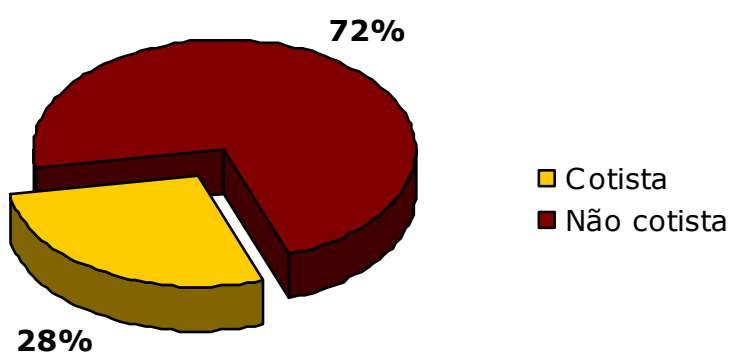

Diferentemente do que aconteceu na categoria "autor", no caso dos réus os candidatos não cotistas são maioria, o que denota que as universidades entraram com recursos porque os candidatos que não concorreram pelo sistema de cotas conseguiram, em primeira instância, o direito à matrícula ou à reserva da matrícula. Nesses casos, as universidades basicamente alegam que cumpriram o disposto na lei estadual.

Dos candidatos cotistas (nove) que foram réus, temos que três não estudaram integralmente no estado do Rio de Janeiro, dois não estudaram integralmente na rede pública, um era negro porém não carente, um era carente de fato, um era negro mas não se autodeclarou como tal no momento de preencher o formulário de inscrição, e um não era carente.

\subsection{Lei questionada}

Nos cento e oito julgados, houve questionamento a pelo menos uma das três leis aqui estudadas. A maioria dos questionamentos foi dirigida à Lei 4151/03, principalmente no que se refere ao critério da carência, que será melhor explicado no próximo item. Consideradas sozinhas, houve mais recursos questionando, de alguma forma, a Lei 3708/01 (que trata da raça) do que a Lei 3254/00 (que trata do estudo na rede pública). No entanto, quando tomadas as duas leis conjuntamente, ou seja, quando elas são ambas questionadas no mesmo caso, houve trinta e quatro julgados. Este número é maior do que quando se considera a soma dos casos que tratam das duas leis isoladamente. 


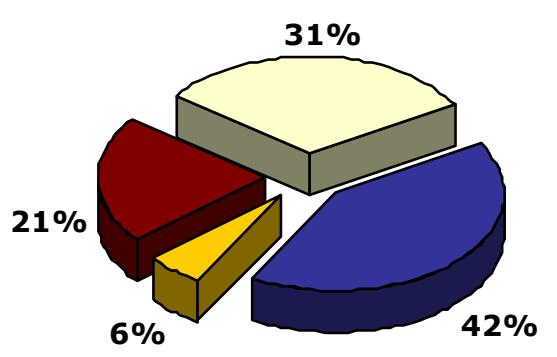

$\square 3254 / 00$

$3708 / 01$

$\square 3254 / 00+$ $3708 / 01$

口4151/03

\subsection{Questionamento}

O gráfico abaixo é bastante similar ao de cima, o que se explica pela quase total coincidência entre as leis questionadas e os tipos de questionamentos. A Lei 3254/00 aborda a questão da rede pública, a Lei 3708/01 aborda a questão da raça e a Lei 4151/03 aborda a questão da carência, da rede pública, da raça e da pessoa com deficiência, em resumo.

A Lei 4151/03, que aparece em maioria, é questionada no aspecto carência e no aspecto rede pública. A Lei 3708/01 coincide, em porcentagem, com a questão da raça, e as Leis 3254/00 e 3708/01, consideradas juntas, coincidem, em porcentagem, com as questões da rede pública e da raça.

\section{Questionamento (108)}

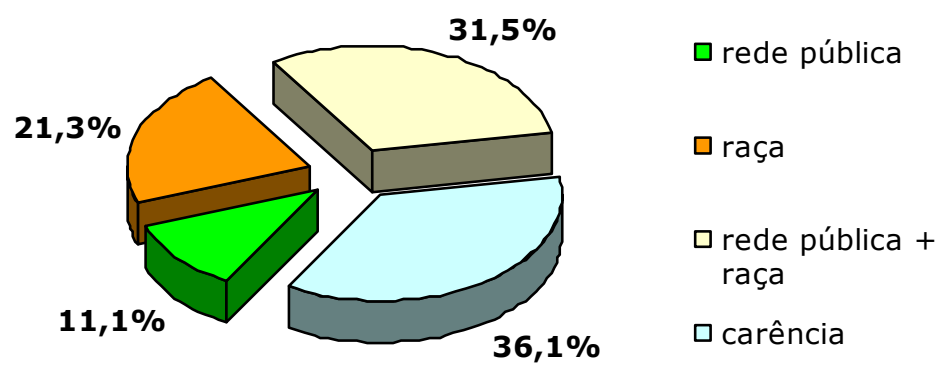




\subsection{Ano de julgamento $x$ lei questionada}

O gráfico seguinte nos mostra quais leis aparecem e quantas vezes elas foram questionadas nos julgados analisados, por ano de julgamento. Algo óbvio, ou natural, de se notar é que nos primeiros dois anos a Lei 4151/03 não aparece justamente porque ela só entrou em vigor depois. Nesses dois primeiros anos, lidera o questionamento comum às Leis 3254/00 e 3708/01. Consideradas singularmente, a Lei 3708/01 (que trata da raça) é significativamente mais questionada do que a Lei 3254/00 (que trata da rede pública), mas esse questionamento cai pela metade no ano de 2004.

É interessante notar que a Lei 4151/03 entrou em vigor em 5 de setembro de 2003, revogando as Leis 3254 e 3708, mas os julgamentos relativos a essas duas leis foram até o ano de 2007.

\section{Lei questionada $x$ ano de julgamento}

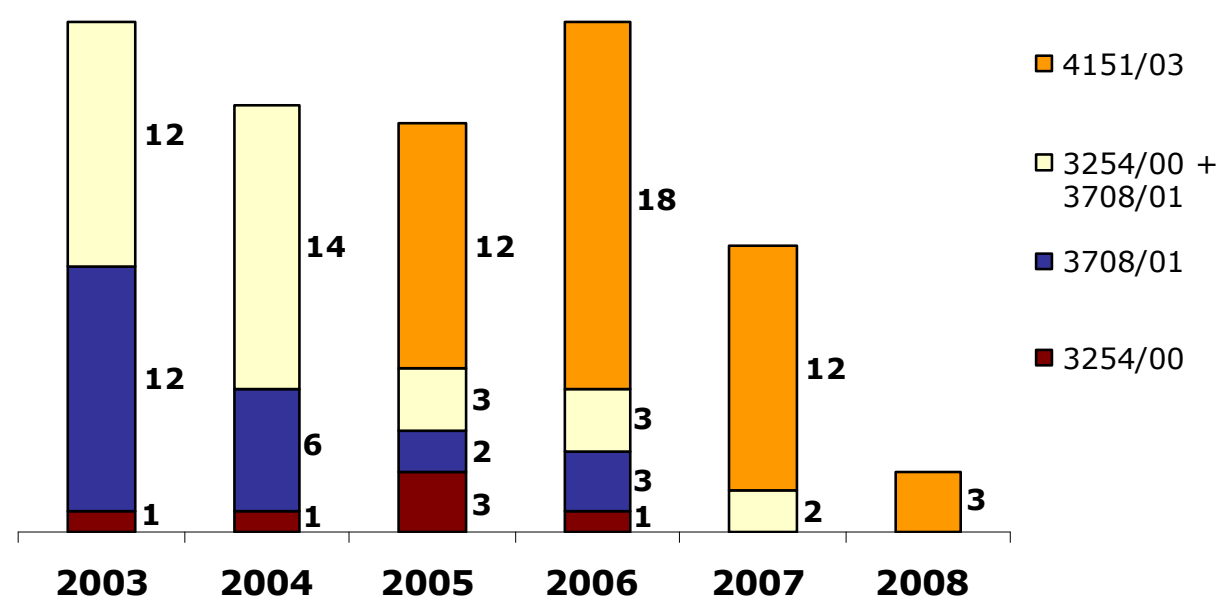

\subsection{Ano de julgamento $x$ questionamento}

O seguinte gráfico guarda estreita semelhança com o de cima: 


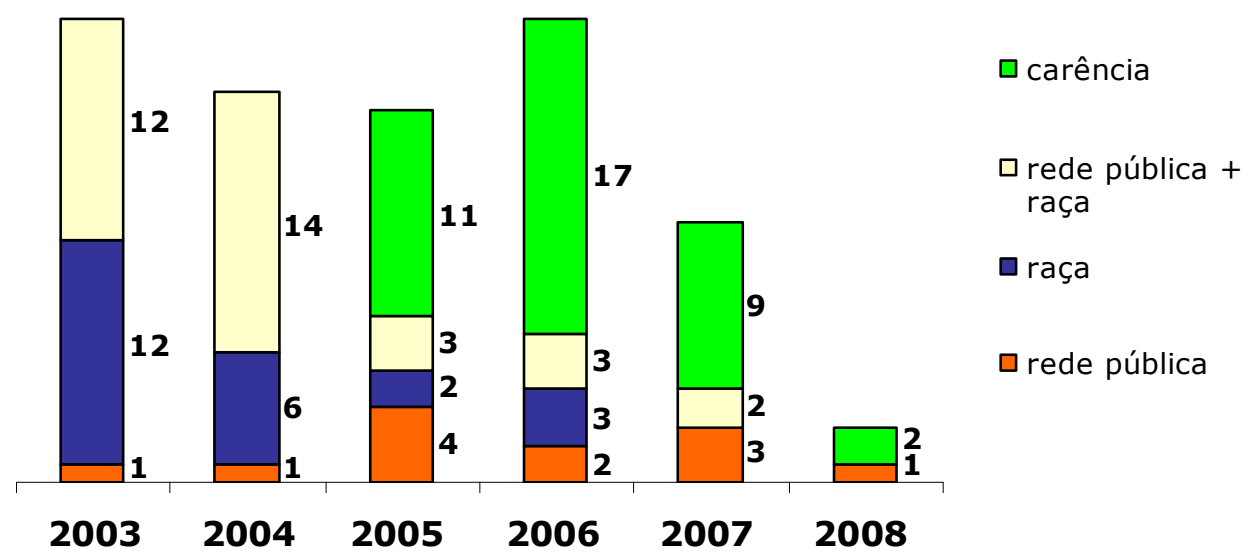

Nos anos de 2003 e 2004, há coincidência no número das leis questionadas e dos tipos de questionamento. Nos anos de 2005 e 2006, percebe-se que a Lei 4151/03 foi questionada dezoito vezes, sendo dezessete vezes para a questão da carência e uma vez para a questão da rede pública. Já no ano de 2007, a Lei 4151/03 foi questionada doze vezes, sendo nove vezes para a questão da carência e três vezes para a questão da rede pública. Por fim, no ano de 2008, a Lei 4151/03 foi questionada três vezes, sendo duas vezes para a questão da carência e uma vez para a questão da rede pública

\subsection{Autor candidato $x$ lei/questionamento}

Abaixo, vemos que leis e que tipo de questionamento os candidatos trazem aos julgados, quando são eles os autores dos recursos.

Aqueles candidatos que concorreram ao vestibular pelo sistema de cotas recorreram, em sua maioria, para questionar o critério carência, ou seja, em regra esses candidatos não conseguiram comprovar sua situação de carência, principalmente porque possuíam renda acima da estabelecida como máxima pela universidade. A Lei 4151/03 não foi ela em si questionada, mas sim o limite máximo de renda estabelecido pela universidade.

Em segundo lugar, os candidatos cotistas questionaram o critério da rede pública instituído pela Lei 3254/00. Dois deles estudaram um tempo na rede privada e mesmo 
assim escolheram concorrer pelo sistema de cotas (tiveram seus recursos negados). Outro estudou um ano na rede privada, pois não conseguiu vaga na rede pública (teve seu recurso provido).

Em terceiro lugar, houve dois candidatos cotistas que questionaram o critério da rede pública instituído pela Lei 4151/03. Eles não estudaram integralmente no estado do Rio de Janeiro, como exigia a lei. Em um dos casos, o relator considerou que a administração pública tem discricionariedade para reservar cotas para estudantes do Rio de Janeiro, e negou o recurso da candidata. No outro caso, o relator considerou que a exigência de estudar no Rio de Janeiro é legal e constitucional, e também negou o recurso da candidata.

Já aqueles candidatos que não concorreram pelo sistema de cotas questionaram majoritariamente as Leis 3254/00 e 3708/01, conjuntamente. Muitos dos fundamentos utilizados foram a violação aos princípios da isonomia, da proporcionalidade e da razoabilidade, entre outros, como será visto mais adiante.

\section{Autor: candidato (73) x lei/questionamento}

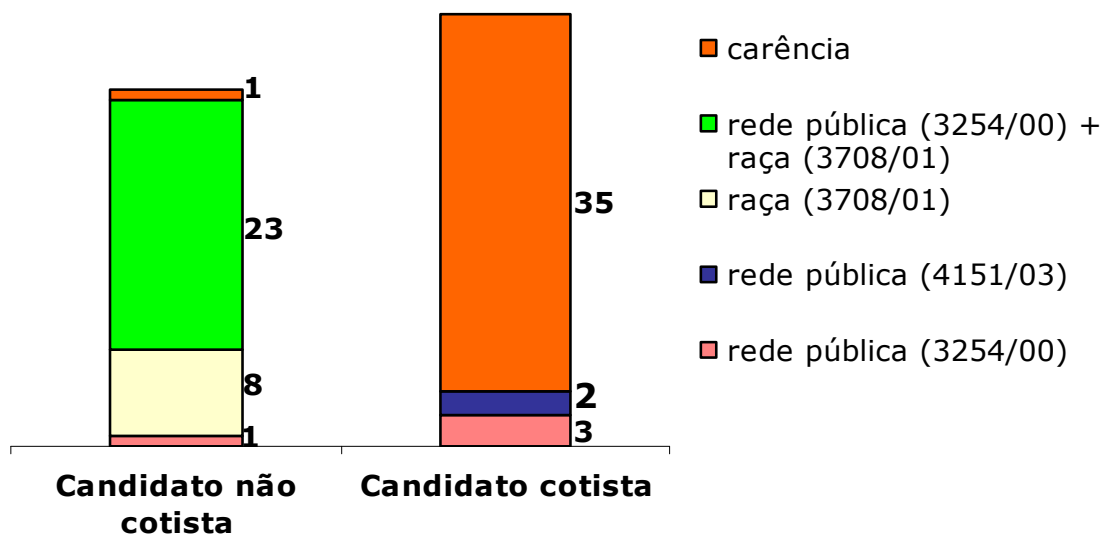

\subsection{Autor x resultado do julgamento}

É interessante notar que a maioria dos recursos foi negada. No caso dos candidatos cotistas e não cotistas, foram $87,5 \%$ de recursos negados em cada caso. Já as universidades tiveram $63 \%$ dos recursos negados. As razões para negar ou dar provimento aos recursos serão vistas em item mais abaixo. 


\section{Autor $\mathrm{x}$ resultado julgamento}

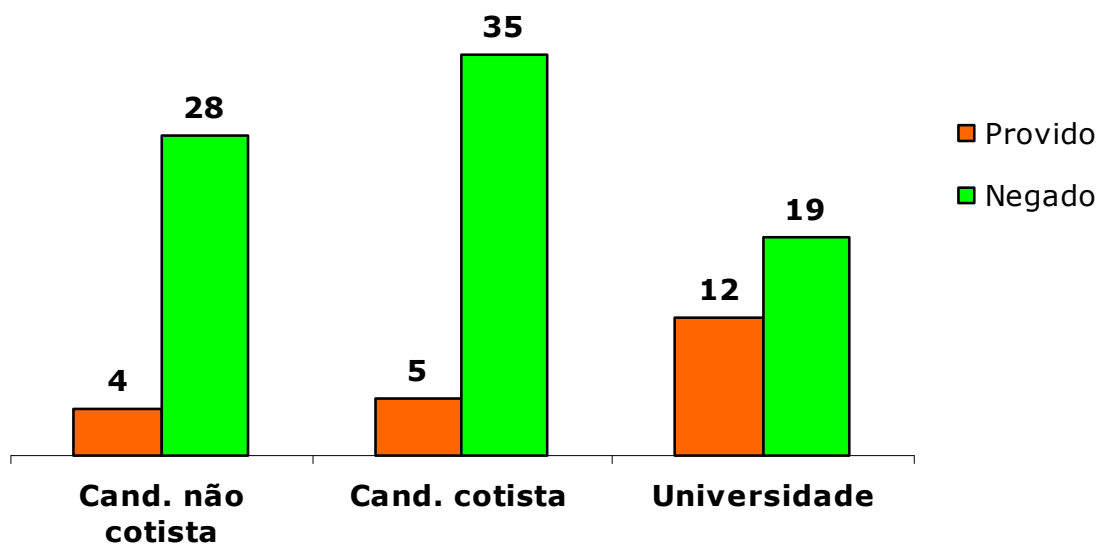

O gráfico abaixo detalha o resultado de julgamento dos autores candidatos que concorreram pelo sistema de cotas. Percebe-se que os candidatos que conseguiram comprovar sua situação de carência nos autos do processo tiveram seus recursos providos e, portanto, foram aceitos na universidade. Também um candidato que concorreu pelo sistema de cotas e não era carente, nos termos definidos pela universidade, teve seu recurso provido, pois se considerou que o limite de renda é critério objetivo sobre o qual o Judiciário não pode intervir, mas no caso o valor que ultrapassava o limite era uma fração desprezível. Outra candidata cotista teve seu recurso provido, pois se considerou que ela tinha direito à matrícula pela lei de cotas, porque havia estudado somente um ano na rede privada, quando não conseguiu vaga na rede pública.

Autor: candidato cotista $(40) \times$ resultado julgamento

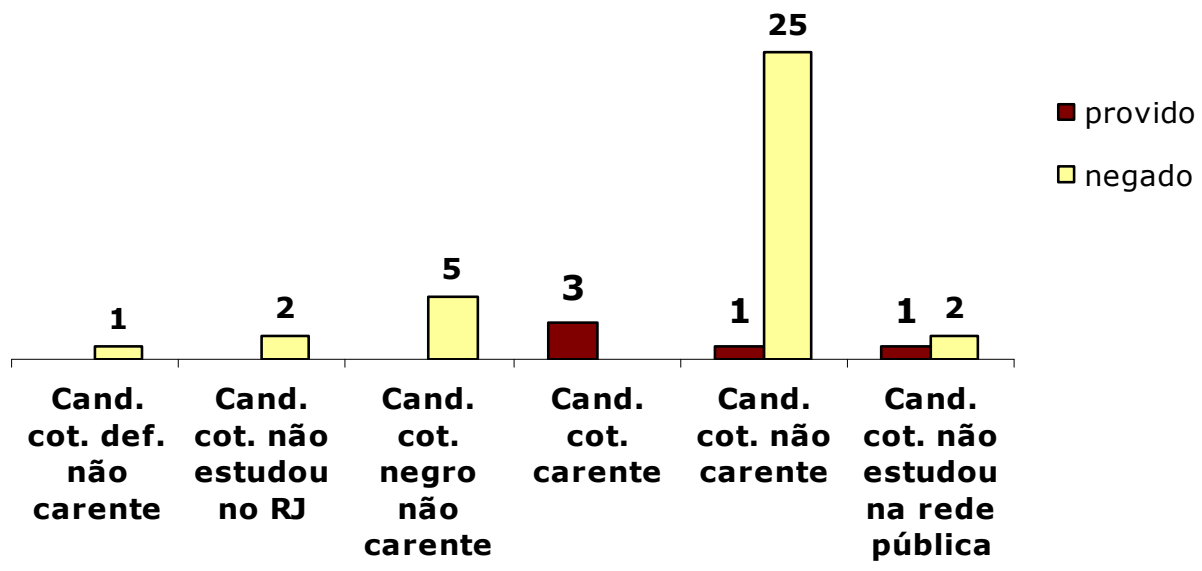




\subsection{Fundamento do candidato}

Como já apresentado, tanto os candidatos que concorreram ao vestibular pelo sistema de cotas quanto os não cotistas recorreram contra as universidades (e em um caso contra o próprio estado do Rio de Janeiro). O número total de candidatos que entraram com recursos é de setenta e três. Os fundamentos dos recursos são os mais variados, sendo que em alguns recursos foram utilizados mais de um fundamento.

Abaixo se apresenta uma tabela que contém esses fundamentos, e o número de vezes que eles aparecem.

\begin{tabular}{lr|}
\hline Carência: violação do princípio da isonomia & 1 \\
Lei 2003: violação do princípio da igualdade & 1 \\
Lei 2003: violação do princípio da razoabilidade & 3 \\
Lei 2003: violação do princípio da supremacia da CF & 1 \\
Carência: deveria ser analisada individualmente & 1 \\
Violação do princípio da legalidade do edital & 1 \\
Carência: questionamento à linha de corte & $\mathbf{2 9}$ \\
Carência: erro de análise & 3 \\
Leis 3254/00 e 3708/01: isonomia & $\mathbf{1 4}$ \\
Leis 3254/00 e 3708/01: razoabilidade & $\mathbf{6}$ \\
Leis 3254/00 e 3708/01: capacidade intelectual & 1 \\
Leis 3254/00 e 3708/01: direito à edução & 1 \\
Leis 3254/00 e 3708/01: impessoalidade & 1 \\
Leis 3254/00 e 3708/01: proporcionalidade & 5 \\
Leis 3254/00 e 3708/01: autonomia universitária & 1 \\
Leis 3254/00 e 3708/01: igualdade & 2 \\
Leis 3254/00 e 3708/01: constitucionalidade & 3 \\
Dificuldade de dizer quem é negro & $\mathbf{4}$ \\
Alunos da rede privada possuem diferentes rendas & 3 \\
Violação do princípio do contraditório & 1 \\
Violação do princípio do devido processo legal & 1 \\
Conclusão do ensino médio antes da vigência da lei & 1 \\
Lei 3708/01: constitucionalidade & 2 \\
Lei 3708/01: problemas na autodedeclaração & 2 \\
Lei 3708/01: razoabilidade & 2 \\
Lei 3708/01: proporcionalidade & 1 \\
Lei 3708/01: isonomia & 3 \\
Lei 3708/01: igualdade & 1 \\
Lei 3708/01: capacidade intelectual & 1 \\
Candidato com nota menor foi aceito & 2 \\
Lei 3254/00: rede pública & 1 \\
Lei 3254/00: igualdade & 1 \\
Lei 3254/00: proporcionalidade & 2 \\
Lei 3254/00: isonomia & 1 \\
Lei 3254/00: razoabilidade & 1 \\
Lei 3254/00: adequação & \\
Lei 3254/00: finalidade & \\
& 2 \\
\hline
\end{tabular}


Alguns dos argumentos acima, como a violação do princípio da razoabilidade, aparecem como questionamento à Lei 3254/00, à Lei 3708/01 e à Lei 4151/03. Esses argumentos foram agrupados, e, abaixo, está uma tabela resumo dos fundamentos que mais aparecem.

\begin{tabular}{|lr|}
\hline Carência: linha de corte & 29 \\
Violação do princípio da isonomia & 19 \\
Violação do princípio da razoabilidade & 12 \\
Violação do princípio da proporcionalidade & 8 \\
Violação do princípio da igualdade & 5 \\
Inconstitucionalidade & 5 \\
Dificuldade de dizer quem é negro & 4 \\
Violação do princípio da capacidade intelectual & 2 \\
\hline
\end{tabular}

Algo curioso a se notar é que o critério da carência é o que mais aparece. Isso sugere que não só os objetivos das ações afirmativas e a constitucionalidade desses programas são questionados no Judiciário, mas também que essas políticas são aceitas, porém possuem determinados aspectos isolados questionados, como o limite máximo de renda determinado pela universidade para que um candidato seja considerado carente.

Também chama a atenção o fato de que a dificuldade de dizer quem é negro no Brasil aparece somente quatro vezes nos julgados analisados, e esse é um dos argumentos contrários às políticas de ações afirmativas mais levantados e discutidos no país (em função, principalmente, do alto nível de miscigenação).

Por fim, também merece destaque o fato de a violação ao princípio da capacidade intelectual ser um fundamento que aparece somente duas vezes nos julgados, quando esse princípio é quase sempre utilizado por aqueles contrários às ações afirmativas, por entenderem que a capacidade intelectual deve ser o único critério de seleção de ingresso em uma universidade.

\subsection{Conteúdo das decisões}

Para entender melhor os argumentos das decisões nos julgados analisados, tentouse, primeiramente, resumir o conteúdo dessas decisões para, em seguida, agrupá-las por categorias elaboradas a posteriori. Assim, as cento e oito decisões foram classificadas 
como a) decisões que de alguma forma, em maior ou menor medida, discutiram as políticas de ações afirmativas; b) decisões que tiveram como fundamentação o fato de o candidato não ter obtido nota suficiente para ser aprovado ainda que as políticas de ações afirmativas não existissem; c) decisões que tiveram como fundamentação formalidades processuais ou cumprimento do edital; d) decisões que tiveram como fundamentação não ser papel do Poder Judiciário intervir nas leis elaboradas pelo poder legislativo ou nos critérios determinados sob a discricionariedade da administração pública; e) decisões que tiveram como fundamentação a presença do periculum in mora e do fumus boni iuris ${ }^{74}$ para a reserva de vaga; e f) decisões que discutiram a comprovação da situação de carência do candidato.

Muitas decisões aparecem em mais de uma categoria, pois tiveram mais de uma fundamentação. Assim, por exemplo, a apelação 200400110830, em cujo julgamento o relator teceu considerações acerca da inconstitucionalidade e da ineficácia da Lei 3708/01 (portanto, essa decisão pode ser classificada no grupo $a$ ), mas reconheceu o fato de o candidato não se classificar mesmo sem a existência da lei de cotas (classificando-se a decisão no grupo $b$ ) e, por isso, negou o recurso do candidato.

a) O primeiro grupo diz respeito, então, às decisões que discutiram as políticas de ações afirmativas. Vinte e sete julgados entram nessa discussão de alguma forma, em maior ou menor medida.

Dentro desse grupo, temos o subgrupo das considerações a respeito da Lei $3708 / 01$.

Em três julgados, reconhece-se a "boa intenção" ou a constitucionalidade das ações afirmativas, entretanto a autodeclaração dos negros é vista como problemática. Merece, aqui, a reprodução de trechos de dois desses julgados.

O primeiro foi extraído do duplo grau de jurisdição 2004.009.00277 julgado em 23 de junho de 2004, pela $2^{\text {a }}$ Câmara Cível, tendo como relator o desembargador Antonio Saldanha Palheiro:

Ademais, a única comprovação da raça é a declaração unilateral feita pelo
candidato optante pelo sistema de reserva de cotas, dando margem a declarações
inverídicas, não encerrando mecanismo seguro para aferição da condiça de

\footnotetext{
${ }^{74}$ Pelo primeiro entende-se que não se pode aguardar o julgamento final para evitar que um dano maior seja causado em virtude da demora do Judiciário. Já pelo segundo entende-se que existe um grau mínimo de certeza onde há uma possibilidade de que as alegações do autor sejam verdadeiras, que serão provadas com maior profundidade ao longo do processo.
} 
beneficiário do sistema instituído pela Lei 3708/2001. De fato, tal sistemática não permite que a Universidade verifique, antes da realização das provas e divisão de vagas, a veracidade do conteúdo da declaração.

Tais medidas afirmativas deveriam se [sic] utilizadas com base em critérios palpáveis e não pela via de autodeclaração, como ocorre na lei, sem implicar lesão de direito alheio, comprometendo a legitimidade da medida.

Com efeito, o tratamento desigual a situações desiguais é corolário da própria ideia de Justiça, no entanto, o fator de diferenciação deve se prestar a uma finalidade acolhida pelo direito, sendo absolutamente vedada a previsão de tratamento abusivo e discriminatório.

Deve-se examinar a existência de uma igualdade proporcional na situação criada com o tratamento diferenciado, para que se evite o esvaziamento da garantia consagrada pelo constituinte.

O segundo foi extraído da apelação 200400112910, julgada em 30 de julho de 2004, pela $17^{a}$ Câmara Cível, tendo como relator o desembargador Rudi Loewenkron:

\begin{abstract}
É piada dizer que no Brasil os brancos foram discriminados por negros e pardos. Entre os desempregados as estatísticas informam predominar os de pele escura. Entre os primeiros despedidos quando a empresa precisa conter custos estão os negros. Nas prisões a raça negra predomina. Nos melhores restaurantes não se vê garçom preto e nas mais altas posições da hierarquia social raramente se nota a presença do negro ou do mulato.

O sistema de reserva de vagas era e é justo, atendendo que o princípio da igualdade de oportunidades constitucional está previsto para os iguais e esse mesmo sistema, corrigidas as suas distorções de implantação já está sendo posto em prática nas universidades federais.

(...)

Esse critério só está pecando pela necessidade de uma melhor definição prática de quem é negro e pardo, afastando-se a exclusividade da confissão própria...
\end{abstract}

Em outros dois julgados, as ações afirmativas são vistas como legítimas, mas considera-se que a Lei 3708 violou o princípio da proporcionalidade ${ }^{75}$, tanto é que seu excesso teria sido corrigido pela Lei 4151/03. Em um dos julgados, adota-se como fundamento o parecer do Ministério Público, que por seu turno cita o parecer de outra procuradora nos autos do agravo de instrumento 4667/2003, da $11^{\text {a }}$ Câmara Cível. Essa procuradora analisa as ações afirmativas à luz do princípio da proporcionalidade e seus elementos: adequação, necessidade e proporcionalidade em sentido estrito. Conclui que as ações afirmativas são adequadas:

\footnotetext{
${ }^{75}$ Daniel Sarmento também discorre sobre o princípio da proporcionalidade. Em relação ao subprincípio da adequação, é necessário aferir se a política é apta a promover os objetivos a que se destina. Em relação ao subprincípio da necessidade, é necessário aferir se não há outro meio mais brando em relação a interesses de terceiros para alcançar os objetivos, desde que promova as finalidades almejadas com a mesma intensidade. Por fim, com relação ao subprincípio da proporcionalidade em sentido estrito, é necessário sopesar o grau de restrição aos interesses daqueles não contemplados pela medida e o grau dos benefícios causados pela medida. Nesse ponto, ressalta o autor, uma das formas de não ferir esse último subprincípio é levar em consideração a desigualdade regional, o número de negros nas diferentes regiões, e a situação em que vivem (2006, p. 165-166).
} 
Por isso, um programa de ação afirmativa se afigura como a única solução para evitar que as melhorias porventura implantadas no futuro, e que não atinjam a presente geração, sejam beneficiados e não façam parte de uma geração perdida.

Com relação ao elemento da necessidade, a procuradora considera que "existe meio mais ameno que também traria resultados, fosse o percentual determinado menor, pois não causaria o desequilíbrio evidente que as cotas em questão estão promovendo". Assim, de acordo com esse trecho, as cotas são adequadas, no entanto na lei examinada (3708/01), a porcentagem é alta, o que acaba constituindo um meio mais gravoso do que o necessário.

Por fim, ainda que fosse possível parar no critério da necessidade, a procuradora vai além e tece comentários a respeito da proporcionalidade em sentido estrito:

... também fica evidente a desproporção do sistema, porque ao invés de promover a reparação para uma minoria, transformou o novo sistema em maioria, por conta das cotas na ordem de mais de cinquenta por cento...

O relator de outro julgado considerou que a Lei 3708/01 é inconstitucional e ineficaz, até porque o problema a ser enfrentado seria de cunho social. O seguinte trecho do voto do relator desembargador José Carlos de Figueiredo, nos autos da apelação 200400110830, julgada pela $11^{\text {a }}$ Câmara Cível em 1 de setembro de 2004, resume a ideia:

\footnotetext{
Ocorre que, no que respeita ao regime de cotas, mais do que imprecisos, os critérios fazem emergir discussão racial e étnica até então inexistente no país, assim como não atacam as reais razões de deformidade no sistema educacional. Se por um lado louvável a tentativa de se levar a cabo políticas afirmativas com tal escopo, infelizmente o regime de cotas, nos moldes em que foi implementado, não se mostrou a solução mais adequada.

Pelo contrário, trata-se de medida que cobre com vestes que a própria experiência histórica tratou de repudiar, uma discussão, repita-se, de cunho socioeconômico.

Ademais, despiciendo singularizar cada incompatibilidade da legislação em comento com a ordem constitucional pátria.
}

De outro lado, um julgado afirma que essa mesma lei fere o princípio da isonomia e que o critério racial não pode ser usado para determinar a ocupação das vagas nas universidades do estado em detrimento do aproveitamento escolar. O agravo de instrumento 200300205825, julgado pela $6^{\mathrm{a}}$ Câmara Cível, tendo como relator o desembargador Nagib Slaibi, tem como fundamentação o parecer do Ministério Público, no qual a procuradora Elaine Costa da Silva considera que:

A decisão conforma-se com o direito demonstrado pelo agravado, com os preceitos constitucionais já referidos e com a irretoquível realidade da falta de 
razoabilidade do diploma legal instituidor das cotas, porquanto não se corrige uma injustiça praticando outra.

Não há de ser o oferecimento condescendente de vagas em universidades que irá prestigiar a cultura negra, pelo contrário, assim se promove mais um ângulo da discriminação.

O valor destas populações deve ser demonstrado pelo esforço, pela luta de seus membros, como já fazem muitos setores, e não por leis protetoras, mas discriminatórias, que nada acrescentam, só diminuem.

O outro subgrupo dentro do grupo de decisões que discutem as ações afirmativas é aquele que trata das Leis 3254/00 e 3708/01 combinadas.

O relator de um julgado considerou que ações afirmativas são constitucionais, à luz do princípio da igualdade em sua vertente material, mas que as Leis 3254/00 e 3708/01 são desproporcionais. Merecem citação alguns trechos da apelação 200500123440, julgada em 24 de janeiro de 2006, pela $8^{a}$ Câmara Cível, cuja relatora foi a desembargadora Odete Knaack de Souza:

No Estado Constitucional, de democracia social, o princípio da igualdade jurídica não mais se limita a uma igualdade formal ou isonômica, como inicialmente concebido pelos revolucionários franceses, ganha traços acentuados de uma igualdade material, ou seja, deixa de ser apenas um dos pilares do Estado de Direito, para tornar-se um dos sustentáculos do Estado Social, sendo comprometido como instrumento hábil para implementar, no plano real, uma igualdade efetiva.

(...)

Contudo, vê-se dos autos que, no intuito de corrigir ou minorar distorções sociais, tais sistemas, da maneira como implantados, vieram a criar outras distorções, inaugurando nova espécie de desigualdade, agora voltada contra os concorrentes do grupo social que disputa o vestibular tradicional, ferindo o princípio da igualdade, em sua face material.

Em um dos julgados, considerou-se que as duas leis ferem o art. 208 da Constituição Federal ${ }^{76}$. Este mesmo julgado e outro consideraram que as leis ferem os princípios da razoabilidade e da objetividade.

\footnotetext{
${ }^{76}$ Art. 208. O dever do Estado com a educação será efetivado mediante a garantia de:

I - ensino fundamental, obrigatório e gratuito, assegurada, inclusive, sua oferta gratuita para todos os que a ele não tiveram acesso na idade própria;

II - progressiva universalização do ensino médio gratuito;

III - atendimento educacional especializado aos portadores de deficiência, preferencialmente na rede regular de ensino;

IV - educação infantil, em creche e pré-escola, às crianças até 5 (cinco) anos de idade;

V - acesso aos níveis mais elevados do ensino, da pesquisa e da criação artística, segundo a capacidade de cada um;

VI - oferta de ensino noturno regular, adequado às condições do educando;

VII - atendimento ao educando, no ensino fundamental, através de programas suplementares de material didático-escolar, transporte, alimentação e assistência à saúde.

$\S 1^{\circ}$ - O acesso ao ensino obrigatório e gratuito é direito público subjetivo.

$\S 2^{\circ}$ - O não-oferecimento do ensino obrigatório pelo Poder Público, ou sua oferta irregular, importa responsabilidade da autoridade competente.
} 
Em outra decisão o relator considerou que as duas leis são inconstitucionais (e concedeu segurança para o candidato).

Por fim, dentro desse subgrupo, um relator discorreu a favor da Lei 3254/00, considerando-a um exemplo constitucional de ação afirmativa, e sobre a miscigenação como um fator positivo no Brasil, mas entendeu que a Lei 3708/01 viola o princípio constitucional da proibição de discriminação racial. O relator da apelação 2862205, desembargador Luiz Eduardo Rabello, julgada em 7 de junho de 2006, pela 11ª Câmara Cível, considerou, a respeito da Lei 3254/00:

Enquanto a Lei $\mathrm{n}^{\mathrm{o}}$ 3.524/2000 representa uma ação afirmativa do Estado do Rio de Janeiro, no sentido de garantir o direito de acesso à educação superior aos estudantes de escolas públicas do próprio Estado, reconhecendo a inferioridade do ensino ministrado nestas instituições educacionais em relação ao das escolas particulares, bem como a precária condição financeira de tais alunos para bancarem seus estudos de qualidade em escolas particulares e, que, portanto, encontram-se em condições de inferioridade em relação aos vestibulandos provenientes de escolas particulares. Tal lei tem a finalidade de compensar através do sistema de cotas, as desigualdades de condições e de acesso ao ensino superior, decorrentes não da própria incapacidade cognitiva, mas sim da falta de condições econômicas e da má qualidade do ensino ministrado pelo próprio Estado.

Embora não se tenha dúvida de que a medida correta e prevista na Carta Magna seja a garantia pelo Estado de ensino fundamental e médio de qualidade na rede pública, para que tais alunos pudessem concorrer em igualdade de condições com os vestibulandos oriundos das escolas particulares, enquanto tal dever estatal não é cumprido, há de se reconhecer que, como medida urgente e transitória, a instituição de cotas para alunos de escolas públicas, na forma prevista na Lei Estadual $n^{\circ} 3.254 / 2000$, afigura-se ação afirmativa oportuna diante da realidade brasileira.

No entanto, no que diz respeito à Lei 3708/01, que instituiu o sistema de cotas para alunos negros, o relator entendeu de modo diferente, concluindo que o tratamento desigual imbuído no conceito de igualdade material não pode ser aplicado quando o elemento diferenciador é raça:

Entretanto, o mesmo não se pode concluir em relação à Lei ${ }^{\circ}$ 3.708/2001, porque ao dar tratamento diferenciado a negros e pardos, mesmo diante da justificativa de se tratar de resgate social e histórico de tais raças, está implícita a discriminação racial, vedada no texto constitucional.

O princípio da isonomia pode e deve amparar leis e medidas que dêem tratamento desigual aos desiguais, a fim de lhe garantir igualdades de oportunidades sociais, entretanto, de forma alguma ampara o tratamento desigual em função da raça ou etnia.

$\S 3^{\circ}$ - Compete ao Poder Público recensear os educandos no ensino fundamental, fazer-lhes a chamada e zelar, junto aos pais ou responsáveis, pela freqüência à escola. 
O terceiro subgrupo dentro do grupo que discute, em alguma medida, as ações afirmativas é aquele que discorre sobre a Lei 4151/03.

$\mathrm{O}$ relator de um julgado considerou que essa lei é na verdade uma discriminação às avessas.

Tem-se, de outro lado, diversas considerações sobre a Lei 4151/03, no que tange à exigência de estudo na rede pública e de estudo no estado do Rio de Janeiro. Por exemplo, aquela feita em um julgado no qual o relator considerou injusta a exigência de estudo integral na rede pública no estado do Rio de Janeiro, presente na Lei 3254/00, que teve esse excesso corrigido pela Lei 4151/03, a partir da qual a exigência passou a ser de estudo somente do $2^{\circ}$ grau no Rio de Janeiro. Na mesma linha em outro julgado considerou-se discriminatória a exigência do estudo na rede pública, e também na rede pública do estado do Rio de Janeiro.

Diferentemente considerou o relator da apelação 200700140955, desembargador Pedro Raguenet, julgada em 16 de outubro de 2007 pela $16^{\text {a }}$ Câmara Cível, que entendeu ser a exigência de estudo no Rio de Janeiro legal e constitucional, pois observa a possibilidade de regionalização prevista no art. $3^{\circ}$, III da Constituição Federal:

\footnotetext{
Assim é que, pela prática desta discriminação em uma "ação afirmativa", o que se prestigia é a igualdade material e não uma igualdade formal, havendo então tratamento diferenciado para com os desiguais visando a equiparar as diferenças, segundo a ótica peculiar do legislador.

Ora, se a dita ação "afirmativa" é de cunho regional (estadual), ditada pelo princípio de prestigiar um amplo acesso ao ensino também estadual, nada mais correto que, dentro da discriminação (das "cotas") se teçam, também, discriminações como forma de escolha daqueles que serão beneficiados.

Perfeitamente admissível, desta maneira, que a lei em questão faça discriminações, fundada que é em justificativa objetiva e razoável, tendo em vista os efeitos e os fins a serem alcançados, como se pode entender do contido no art. 3o, inciso III da Constituição vigente, quando fala das desigualdades regionais.
}

Ainda dentro desse subgrupo, dois relatores de dois julgados consideraram que a Lei 4151/03 está em consonância com o art. 206 da Constituição Federal, que prevê, dentre outras coisas, que um dos princípios do ensino é a igualdade de condições para o acesso na escola, o pluralismo de ideias e de concepções pedagógicas e a garantia do padrão de qualidade.

Finalmente, o último subgrupo desse primeiro bloco de decisões é aquele que discorre sobre as ações afirmativas em um sentido mais amplo, sem necessariamente entrar em aspectos mais específicos das leis aqui estudadas. 
Os sete julgados encontrados relatados pelo desembargador Cláudio de Melo Tavares chamam a atenção, pois o desembargador discorre extensivamente sobre as ações afirmativas e sobre princípios, e apresenta números da situação dos negros e dos pobres, os quais comprovam que os negros são os mais pobres dentre os pobres. O magistrado ainda reconhece a legitimidade das ações afirmativas e das leis e fala do papel do Judiciário na consolidação de políticas que buscam a igualdade.

Inicialmente, é muito interessante a referência que o agravo de instrumento 200300204409, julgado em 16 de outubro de 2003, pela $11^{\text {a }}$ Câmara Cível, faz à famosa Oração aos Moços, de Rui Barbosa, na qual fica clara a regra do tratamento desigual aos desiguais: "A regra da igualdade não consiste senão em aquinhoar desigualmente os desiguais, na medida em que desigualam".

Segue considerando que não há como falar em igualdade de oportunidades, quando não há uma igualação prévia, de origem. Ou seja, os "competidores” partiriam de posições diferentes, o que não seria justo.

Lembra, também, que já existem cotas para pessoas com deficiência em diversos lugares e no poder público e cotas para mulheres nos partidos políticos.

Faz uma menção, com a reprodução de trechos de palestra proferida no Seminário Discriminação e Sistema Judiciário Brasileiro, pelo Ministro Marco Aurélio, que comenta o papel do Judiciário, à luz do exemplo do importante papel histórico da Suprema Corte norte-americana no campo da concretização dos valores básicos da Constituição, e ainda cita a sua atual colega do Supremo Tribunal Federal, Ministra Carmen Lúcia. O trecho citado aqui é longo, mas o seu conteúdo justifica toda a transcrição:

O que pode o Judiciário fazer neste campo? Pode contribuir, e muito, tal como a Suprema Corte dos Estados Unidos da América após a Segunda Guerra Mundial. Até, então, tinha-se apenas a atuação do legislador. Percebeu aquela Suprema Corte que precisava, realmente, sinalizar para a população, de modo que prevalecessem, na vida gregária, os valores básicos da Constituição norteamericana. Toda e qualquer interpretação de um ato normativo revela um ato de vontade. E aí vale repetir: os homens não são feitos para as leis, mas as leis para os homens. Qual deve ser a postura do Estado-juiz diante de um conflito de interesses? Há de ser única: não de potencializar a dogmática para, posteriormente, à mercê dessa dogmática, enquadrar o caso concreto. Em face de um conflito de interesses, deve o juiz idealizar a solução mais justa considerada a formação humanística que tenha e, após, buscar o indispensável apoio no direito posto. Ao fazê-lo cumprirá, sempre, ter presente o mandamento constitucional de regência da matéria. Só teremos a supremacia da Carta quando, à luz dessa mesma Carta, implementarmos a igualdade. A ação afirmativa evidencia o conteúdo democrático do princípio da igualdade jurídica, e, neste caso, cabe citar uma pensadora do Direito, a nossa Carmen Lúcia Antunes Rocha: "A ação afirmativa é um dos instrumentos possibilitadores da superação do problema do não cidadão, daquele que não participa 
política e democraticamente como lhe é na letra da lei fundamental assegurado, porque não se lhe reconhecem os meios efetivos para se igualar com os demais. Cidadania não combina com desigualdades. República não combina com preconceito. Democracia não combina com discriminação... Nesse cenário sócio-político e econômico, não seria verdadeiramente democrática a leitura superficial e preconceituosa da Constituição, nem seria verdadeiramente cidadão o leitor que não lhe buscasse a alma, apregoando o discurso fácil dos igualados superiormente em nossa história pelas mãos calejadas dos discriminados. É preciso ter sempre presentes essas palavras. A correção das desigualdades é possível. Por isso façamos o que está a nosso alcance, o que está previsto na Constituição Federal, porque, na vida, não há espaço para o arrependimento, para a acomodação, para o misoneísmo, que é aversão, sem se querer perceber a origem, a tudo que é novo..." (grifos da autora)

Por fim, o desembargador faz referência ao professor José Jorge de Carvalho (Proposta para implementação de um sistema de cotas para negros na Universidade de Brasília), que discorre sobre a importância de considerar os negros separadamente dos pobres e da importância das cotas como um primeiro passo:

\begin{abstract}
Se abrirmos cotas para os estudantes de baixa renda, de fato ajudaremos indiretamente a muitos indivíduos negros. Contudo, os dados de que dispomos nos alertam para o fato de que os brancos pobres já contam com uma vantagem de escolaridade frente aos negros. Se abrirmos cotas para pobres, portanto, independentemente de sua cor, na verdade estaremos contribuindo para a reprodução ou até mesmo a intensificação da desigualdade dentro desse segmento dos pobres brasileiros... Ou seja, faremos uma ação afirmativa de classe às expensas de continuar discriminando os negros, cientes de que o fazemos.

$O$ único modo de deter e começar a reverter o processo crônico de desvantagem dos negros no Brasil é privilegiá-la conscientemente, sobretudo naqueles espaços em que essa ação compensatória tenha maior poder de multiplicação. Eis porque a implementação de cotas se torna inevitável. Na medida em que não poderemos reverter inteiramente esta questão a curto prazo, podemos pelo menos dar o primeiro passo, qual seja, incluir negros na reduzida elite pensante do país. (grifos da autora)
\end{abstract}

Em um julgado, o relator ressalta que a ação afirmativa revela a faceta contemporânea do princípio da igualdade, e, em outro, discorre sobre as ações afirmativas nos Estados Unidos e até mesmo os livros de Ronald Dworkin são mencionados. Na apelação 20030013525, julgada em 11 de maio de 2004 pela $7^{\text {a }}$ Câmara Cível, o relator desembargador Maurício Caldas Lopes considera que:

Tais ações, autênticos agentes de mudança social, como acabou por conceituá-las o direito constitucional norte-americano, não prescindem dos limites que lhes hão de ser necessariamente postos pelos princípios da razoabilidade e da proporcionalidade e que, tudo indica, acabaram por desrespeitados pelas leis em apreço, ao reservarem nada menos do que $90 \%$ das vagas oferecidas no concurso vestibular, aos alunos provenientes da rede pública (Lei 3.524/2000) e aos que se declarassem negros ou pardos (Lei 3.708/2001), discriminando - como se 
constata a olho desarmado - os que assim não se qualifiquem mas que são, por igual, destinatários da mesma igualdade jurídica...

Pelo trecho transcrito acima, depreende-se que o relator entende serem as ações afirmativas uma discriminação injusta, pois excluem as pessoas não beneficiadas por elas. Por outro lado, é adotado como fundamento da decisão o parecer do Ministério Público, que considera as ações legítimas, e apenas no caso analisado considera que as leis violam o princípio da proporcionalidade por estabelecerem cotas muito elevadas. Neste parecer, a procuradora de justiça Maria Eugênia Monteiro Cavalcanti discorre a respeito:

\begin{abstract}
Em seu novo livro Sovereign Virtue, Dworkin posiciona-se pela constitucionalidade do sistema, em especial na questão educacional, com base em um estudo chamado The shape of the river, que analisa as estatísticas sobre o papel e o impacto do programa de ação afirmativa nos últimos trinta anos, para concluir que houve significativo avanço na condição econômica das minorias beneficiadas pelo programa. No entanto, sempre que se tem em mente cotas nos Estados Unidos, estas são em número diminuto, em torno de $15 \%$.

Conquanto as leis sobre ação afirmativa estejam em consonância com a moderna doutrina constitucional, torna-se necessário, contudo, avaliar se o quantum determinado para reserva possui conteúdo razoável. Havendo desproporção exagerada, o sistema, como um todo, se desestabilizará.
\end{abstract}

A procuradora segue comentando as leis sob análise: "Em nosso entendimento, aquelas leis acabaram estabelecendo uma lamentável inversão, destinando pequena parcela de vagas para aqueles que não se enquadram naquelas leis de cunho excepcional”.

b) $\mathrm{O}$ segundo grupo de julgados diz respeito àquelas decisões que tiveram como fundamento principal de decisão o fato de que o candidato não seria aprovado ainda que as leis de cotas não existissem. Abaixo está um trecho que resume os trinta e um julgados desse bloco, e que foi retirado do agravo de instrumento 200300203810, julgado em 5 de agosto de 2003, pela $5^{\text {a }}$ Câmara Cível, cujo relator foi o desembargador Antonio Cesar Siqueira:

Para que se possa considerar a verossimilhança do direito alegado, deveria o autor pré-constituir prova no sentido de que, afastada a aplicação das leis que instituíram as cotas, o candidato, aprovado no vestibular, estaria classificado em lugar correspondente ao número de vagas oferecidas para cada opção feita.

c) O terceiro grupo de julgados diz respeito a formalidades processuais ou relativas ao cumprimento do edital. São vinte no total. 
Em dois deles, ressaltou-se que a estreita via do writ não permite a discussão sobre a discricionariedade da Administração Pública. Em outros dois, em sentido parecido, o relator considerou que em sede de mandado de segurança não há como comprovar que a autora entregou documento para atestar sua renda per capita.

Em outro, o relator alegou que a exigência de apresentação pelo candidato das contas de luz, quando todos os outros documentos já comprovaram a situação de carência, configura abuso da administração pública.

No caso de um candidato que se formou no ensino médio antes da entrada em vigor da Lei 3254/00, o relator confirmou que ela atinge somente os candidatos que ainda estavam cursando o ensino médio quando da sua entrada em vigor.

Em três casos que trataram das duas primeiras leis, nos quais a decisão de segunda instância foi proferida depois da entrada em vigor da Lei 4151/03, os processos foram extintos sem julgamento do mérito. Em um caso específico, o relator concedeu liminar para candidata se matricular em razão de a Lei 3708/01 ter sido revogada. Em outro, o relator considerou que a candidata teria se classificado não fosse a reserva de vagas e que a Lei 3708/01 foi declarada inconstitucional pelo Órgão Especial do Tribunal de Justiça do estado do Rio de Janeiro (em razão desses fatos, deu provimento ao recurso da candidata para que ela se matriculasse na universidade).

No que diz respeito ao critério do estudo na rede pública, em três julgados considerou-se que um único ano cursado em escola particular, ou tendo o aluno bolsa integral (dois julgados) ou porque o aluno não conseguiu vaga na rede pública (um julgado), não afasta a presunção de miserabilidade do candidato.

Em outro julgado, o relator considerou que houve cumprimento do edital, que fala em instituição mantida pelo poder público. O candidato que concorreu pelo sistema de cotas havia estudado no Instituto Metodista de Petrópolis, e restou comprovado que esse Instituto é mantido pelo estado, atendendo ao disposto no edital.

O pedido de um candidato para se matricular na universidade não foi deferido porque ele estudou quatro anos na rede privada, não cumprindo, portanto, o edital. $\mathrm{Na}$ mesma linha outro pedido também foi indeferido em razão de o edital ser objetivo e não ter sido cumprido.

O caso de erro de preenchimento do formulário de inscrição, quando uma candidata deixou de assinalar que era negra, e, portanto, não concorreu pelo sistema de cotas, não foi revisto, visto que a relatora considerou que esse erro não poderia ser considerado escusável. 
Por fim, em outro caso, um relator negou recurso da candidata porque ela já havia ganhado em primeira instância.

d) O quarto grupo de julgados diz respeito às decisões em que o relator considerou, de forma explícita, que não seria papel do Poder Judiciário intervir nos critérios estabelecidos pela administração pública ou valorar as leis promulgadas no legislativo. Cinco julgados estão nesse bloco.

Em quatro decisões considerou-se que o edital (duas) ou o limite de renda (duas) são objetivos, não podendo ser objeto de discussão do Judiciário. Na apelação 20060014424, julgada em 21 de novembro de 2006, pela $1^{\text {a }}$ Câmara Cível, a relatora desembargadora Vera Maria Van Hombeeck entendeu que os critérios fixados pela Administração Pública foram bastante razoáveis "não cabendo ao Judiciário qualquer ingerência neste juízo de valor, sob pena de adentrar no mérito administrativo".

A quinta decisão desse bloco considerou que não cabia ao Poder Judiciário valorar uma lei como injusta (o caso tratava de um candidato que havia estudado parte do ensino médio no Espírito Santo, quando a Lei 4151/03 exigia que o estudo tivesse sido no Rio de Janeiro). No agravo de instrumento 200700211039, julgado em 9 de maio de 2007, pela $20^{a}$ Câmara Cível, o relator desembargador Marco Antonio Ibrahim considerou que

\footnotetext{
O Juiz pode considerar que uma lei é injusta (o que é muito diferente de ser reputada inconstitucional) e nem por isso pode deixar de aplicá-la. No sistema democrático e no Estado de Direito só ao legislador cabe a modificação de leis injustas, sendo temerário autorizar que o Poder Judiciário possa assumir tais funções.
}

e) O penúltimo bloco compreende as decisões que tiveram como fundamentação a presença do fumus boni iuris e do periculum in mora para a reserva de vaga. Basicamente, as nove decisões que estão nesse bloco concederam o direito para o candidato da reserva da matrícula, até que se julgasse o mérito ou se comprovasse que o candidato teria nota suficiente para se classificar.

Em um dos casos, o candidato agravou, pois a sentença apenas concedeu o direito à reserva da vaga, e não o direito de matrícula. Em segunda instância, o relator desembargador Jessé Torres do agravo de instrumento 200300204944, julgado em 18 de julho de 2003 pela $2^{\mathrm{a}}$ Câmara Cível, considerou que: 
No caso, entendeu de deferir parcialmente o pleito, não merecendo reforma. A reserva de vaga não impõe ao recorrente lesão de direito grave ou de difícil reparação, ao passo que a determinação de sua matrícula, desde logo, poderia preterir outros candidatos que, como o recorrente, obtiveram pontuação inferior ao limite mínimo exigido. Presentes o risco de perecimento do direito e o relevante fundamento jurídico do pedido, em matéria enevoada pelo aparente descompasso entre os bons propósitos e a pertinência dos critérios e procedimentos positivados para implementá-los, há de manter-se a liminar deferida (Lei $\mathrm{n}^{\mathrm{o}} 1.533 / 51$, art. $\left.7^{\circ}, \mathrm{II}\right)$

f) Finalmente, no último bloco estão trinta e três decisões que discutiram a situação de carência do candidato.

Três candidatos conseguiram comprovar que são carentes, nos autos do processo, e obtiveram o direito à matrícula (em um dos julgados, o relator entendeu que a UERJ errou ao avaliar a renda declarada, que era total da família e não por pessoa; em outro considerou que o seguro desemprego, uma renda temporária, não deve ser computada na renda familiar).

Em vinte e sete julgados, considerou-se que não havia direito líquido e certo, que o edital era objetivo e que de acordo com as informações preenchidas no questionário de inscrição não ficou comprovada a situação de carência. Em um deles o relator avaliou que, mesmo a candidata tendo renda dezesseis reais acima do limite estabelecido pelo edital, o critério é objetivo e deve ser observado. Merece transcrição o trecho da apelação 200600144249, julgada em 21 de novembro de 2006 pela 1ª Câmara Cível, na qual a relatora desembargadora Vera Maria Van Hombeeck bem resume o posicionamento da maioria dos julgados deste bloco:

\footnotetext{
Não seria razoável, como argumenta o impetrante, que a universidade analisasse a situação individual de cada candidato, a fim de se chegar a uma conclusão sobre sua carência. Isto por certo inviabilizaria o vestibular, tendo em vista as peculiaridades de cada caso, bem como o grau de subjetividade envolvido.

Por isso, necessário se faz a fixação de critérios objetivos, que permitam a realização do certame, atendendo ao maior número de estudantes.

Somente a título de argumentação, imaginemos uma situação onde dois candidatos concorram a uma mesma vaga. $O$ que se classificou em posição melhor não preenche os requisitos do certame, percebendo um pouco mais do que o especificado. Porém, o que se classificou imediatamente após este primeiro, preenche rigorosamente as exigências. Neste norte, seguindo o raciocínio do impetrante, aquele que preencheu os requisitos teria que ser desclassificado, em razão da classificação que não atendeu o edital.

Não há como atender a todos os estudantes carentes, fornecendo universidade pública indistintamente, embora este fosse o ideal. E é neste sentido que as regras são fixadas, de modo a atender àqueles que mais necessitam.
}

Em dois julgados, o candidato que possuía uma renda per capita que ultrapassava um pouco do limite previsto no edital teve seu recurso provido. No primeiro deles, a 
apelação 200700130389, julgada em 17 de outubro de 2007 pela 17 Câmara Cível, o relator desembargador Elton M. C. Leme entendeu que:

Entretanto, em se tratando de situação objetivamente fronteiriça, em que o candidato ultrapassa, na demonstração de sua renda, desprezível fração do limite monetário indicado na lei, não é possível, pelo mesmo critério de razoabilidade, afastar a condição de hipossuficiência econômica, à medida que a situação fática cumpre com exatidão a finalidade social objetivada pelo legislador e pelo próprio edital do certame.

No outro, o relator considerou que o candidato já estava no segundo ano de faculdade e que existia o risco de ferir o princípio da razoabilidade caso o limite de renda fosse interpretado de forma muito estrita. 


\section{CONSIDERAÇÕES SOBRE OS JULGADOS}

A presente dissertação se propôs a estudar o princípio da igualdade e as ações afirmativas, apresentando também os números oficiais que revelam em qual situação o negro no Brasil se encontra hoje. Esse estudo, que correspondeu à primeira parte deste trabalho, foi imprescindível para a análise dos julgados na segunda parte.

O principal intuito dessa análise foi conhecer quais argumentos são utilizados pelos magistrados ao julgarem casos que trataram das cotas instituídas pelas legislações no estado do Rio de Janeiro, de 2001 a 2008. Mais especificamente, averiguar se o argumento da existência da discriminação racial era mais ou menos utilizado do que o argumento da desigualdade social.

Para responder a essa pergunta, o caminho traçado contemplou três subperguntas, visto ter existido mais de uma lei instituídora de cotas no estado do Rio de Janeiro. Em resumo:

1) Com relação à Lei 3524/2000, que instituiu cotas para alunos oriundos da rede pública, quais são os argumentos mais utilizados pelos magistrados?

2) Com relação às Leis 3254/2000 e 3708/2001, o argumento racial é mais ou menos utilizado que o argumento social?

3) Com relação à Lei 4151/2003, que instituiu cotas para alunos carentes oriundos da rede pública e carentes negros, dentre outros, a carência, a origem escolar ou a raça é o argumento mais mencionado?

Para responder a essas perguntas, as hipóteses de resposta que foram elaboradas foram as seguintes:

1) O uso das ações afirmativas para o ingresso de alunos oriundos da escola pública é legítimo, porém deve-se investir na educação de base (nos ensinos fundamental e médio) para que os alunos que estudaram na rede pública tenham condições de passar no vestibular sem que seja necessária a reserva de vagas.

2) No período em que a Lei $3524 / 2000$ e a Lei 3708/2001 estavam ambas em vigor, houve mais ações judiciais de candidatos que não passaram no vestibular questionando a violação ao princípio da igualdade pelo uso de raça como forma de reserva de vagas. Ou seja, a Lei 3708 foi mais questionada do que a Lei 3524. Outra hipótese, que não exclui a primeira, é a existência de julgados que trataram 
da discussão sobre a desproporcionalidade da reserva de $40 \%$ das vagas para alunos negros.

3) A hipótese é que a maioria dos julgados que se debruçaram sobre a Lei 4151/2003 concentrou-se mais na discussão do requisito da carência e menos na discussão das subcotas (raça e origem escolar).

O passo, agora, é analisar se essas hipóteses se confirmaram com base nos dados que foram apresentados no capítulo anterior.

\section{1) Subpergunta $n^{\circ} 1$}

De cento e oito julgados, houve seis que questionaram somente a Lei 3254/2000. Essa lei, promulgada em 2000, só foi ter o seu primeiro julgamento no ano de 2003. Em 2004 houve mais um caso julgado; em 2005, três; e em 2006, mais um.

A UERJ esteve duas vezes figurando no polo ativo dos recursos. Basicamente, a universidade recorreu, pois a sentença de primeiro grau determinou a matrícula para (i) candidata que estudou na rede pública de outra unidade da federação que não o Rio de Janeiro, e (ii) candidato que estudou em Instituto privado mantido pelo poder público. Nos dois casos o relator negou o recurso da UERJ, pois considerou (i) injusto exigir o estudo integralmente no Rio de Janeiro, e (ii) que o edital foi cumprido, pois fala em instituição mantida pelo poder público.

Candidatos apareceram quatro vezes como autores, sendo um candidato que concluiu o ensino médio antes da entrada em vigor da lei, e os outros três que concorreram pelo sistema de reserva de vagas, mas não foram aceitos pois não estudaram integralmente na rede pública.

No que tange aos argumentos utilizados pelos relatores dos seis julgados, temos que (i) um deles considerou que a exigência de estudo (na rede pública) do estado do Rio de Janeiro viola o princípio da razoabilidade e da isonomia substancial; (ii) outro simplesmente considerou que a lei não se aplica aos alunos que já terminaram o ensino médio antes da sua entrada em vigor e que o candidato não teria sido aprovado mesmo sem a reserva de vagas; (iii) outro relator considerou que o instituto onde o candidato estudou é mantido pelo poder público e inclusive é gratuito, tendo razão, então, o candidato; (iv) outro considerou que a lei, mesmo tendo constitucionalidade duvidosa, era clara quanto à exigência de estudo na rede pública, não assistindo razão o candidato; (v) outro relator considerou que, se o objetivo da lei é estabelecer um método diferenciado de acesso ao 
ensino superior para aquelas pessoas hipossuficientes que de outro modo teriam êxito, então a candidata que estudou somente um ano na rede privada por não ter conseguido vaga na rede pública deve ser aceita pelo sistema de cotas; (vi) outro relator, por fim, considerou que os requisitos legais do edital não foram cumpridos pela autora.

Tendo em vista o exposto acima, conclui-se que um argumento discute as próprias ações afirmativas, e cinco argumentos dizem respeito ao cumprimento do edital da universidade. Assim sendo, a hipótese levantada para essa subpergunta não se confirma, já que nenhum desembargador defendeu que o uso das ações afirmativas para o ingresso de alunos oriundos da escola pública é legítimo, porém deve-se investir na educação de base (nos ensinos fundamental e médio) para que os alunos que estudaram na rede pública tenham condições de passar no vestibular sem que seja necessária a reserva de vagas.

\section{2) Subpergunta $n^{\circ} 2$}

De centro e oito julgados, houve sessenta e três que questionaram a Lei 3254/2000, a Lei 3708/2001, ou as duas juntas. Conforme ilustrado pelo gráfico da página 94, a partir de 2003, ano de julgamento da primeira ação que tratou das cotas estaduais, até o ano de 2008, último ano da pesquisa, foram trinta e quatro julgados que trataram das Leis $3254 \mathrm{e}$ 3708 de forma conjunta, vinte e três que trataram somente da Lei 3708 e seis que trataram somente da Lei 3254.

Os julgados que discutiram, de alguma forma, a Lei 3254 já estão explicados na análise da subpergunta 1.

Dos julgados que discutiram somente a Lei 3708, em oito o autor foi candidato que não concorreu pelo sistema de cotas e em doze o autor foi a Universidade do Estado do Rio de Janeiro. Os outros três julgados referem-se a duas arguições de inconstitucionalidade e a uma representação por inconstitucionalidade.

Naquelas ações nas quais o autor foi um candidato não cotista (e o réu correspondente a UERJ), em regra, a alegação foi de que a Lei 3708/2001 era inconstitucional, o fato de ela violar o princípio da proporcionalidade, razoabilidade, isonomia e capacidade intelectutal, o fato de a autodeclaração não garantir a igualdade, e o candidato com menor nota conseguir se matricular.

Nos julgamentos dessas ações, dois relatores consideraram a boa intenção do legislador nas ações afirmativas para negros e alunos da rede pública, mas que a autodeclaração, no caso dos negros, dá margem a erros e fere o princípio da igualdade. Outro concedeu liminar para candidata se matricular porque a Lei 3708 teve sua vigência 
suspensa. Outro concedeu liminar para reservar matrícula até o final do julgamento. Dois relatores consideraram que a candidata não teria se classificado mesmo sem as leis de cotas. Outro entendeu que a Lei 3708 viola o princípio constitucional da proibição de discriminação racial (considerou a miscigenação como um fator positivo no Brasil) e que a candidata não teria se classificado mesmo sem a reserva das vagas. Por fim, um relator teceu considerações acerca da inconstitucionalidade e da ineficácia da lei de cotas, mas reconheceu não poder apreciar o direito do candidato pela via mandamental, além do fato de o candidato não se classificar mesmo sem a reserva de vagas.

Aquelas ações nas quais o autor foi a UERJ (e o réu correspondente foi candidato não cotista, com exceção de um candidato negro que concorreu pelo sistema de cotas), a universidade, alegou, em regra, que os candidatos não atenderam o que dispunha o edital, que a instituição estava apenas cumprindo a lei estadual.

No caso das sentenças favoráveis aos alunos não cotistas, das quais a UERJ recorreu, foi concedida liminar para reservar a vaga para o candidato até o julgamento do mérito, ou foi provido o próprio pedido para se matricular. Nos julgamentos em segunda instância, em seis a liminar foi confirmada ao considerar presentes os seus requisitos ensejadores. Em quatro o relator avaliou que os canditados não teriam se classificado mesmo sem a lei de cotas e, assim, cassou a liminar. Em outro o relator considerou que a Lei 3708/2001 fere o princípio da isonomia, pois o critério racial não pode determinar a ocupação das vagas nos universidades do estado em detrimento do aproveitamento escolar.

No caso específico da candidata cotista, ela não se autodeclarou negra no momento de preencher o formulário e, assim, acabou não concorrendo pelo sistema de cotas. No entanto, pleiteou a vaga reservada e alegou erro no momento do preenchimento. Houve liminar determinando a matrícula, da qual a UERJ recorreu. O relator, ao final, considerou que o erro de preenchimento não foi escusável, cassou a liminar e deu provimento ao recurso da universidade.

Ainda considerando a Lei 3708/2001 de forma isolada, houve duas arguições de inconstitucionalidade e uma representação por inconstitucionalidade, todas julgadas pelo Órgão Especial do Tribunal de Justiça. Em resumo, o julgamento da arguição 15/2005, cujo relator foi o desembargador Silvio Teixeira, considerou que, em tese, as "ações afirmativas que têm por objetivo estabelecer reserva de cota mínima obrigatória em benefício das minorias raciais em universidades públicas" são legítimas, mas no caso da Lei 3708/2001 houve ofensa ao princípio da proporcionalidade e, por isso, a lei foi 
declarada inconstitucional com efeitos $e x$-tunc ${ }^{77}$. É válido transcrever, aqui, alguns trechos dessa decisão.

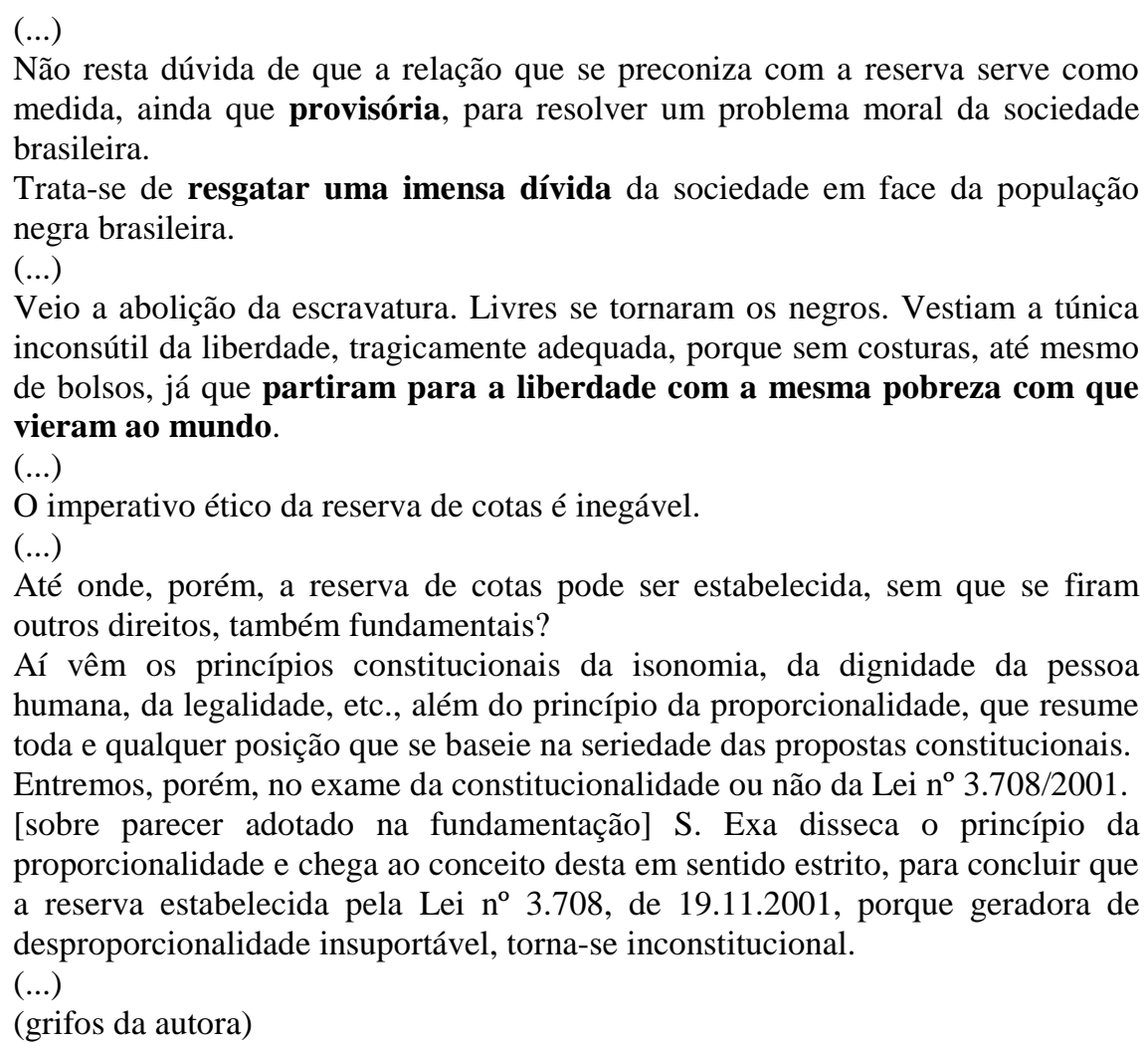

Os trechos grifados na transcrição acima ilustram alguns dos conceitos estudados nesta dissertação, tais como o fato de as políticas de ações afirmativas serem temporárias (provisórias), a discussão sobre a justiça compensatória (resgatar uma imensa dívida) e o fato de os pontos de partida serem diferentes (partiram para a liberdade com a mesma pobreza com que vieram ao mundo).

Nas outras duas decisões, o processo foi extinto sem julgamento do mérito, em razão do advento da Lei 4153/2003.

Finalmente, dos julgados que discutiram tanto a Lei 3254 quanto a Lei 3708, em vinte e dois o autor foram candidatos que não concorreram pelo sistema de cotas e em dez foi a UERJ. Um recurso teve como autor tanto uma candidata não cotista como a UERJ, e outro recurso disse respeito a uma arguição de inconstitucionalidade.

No caso dos autores candidatos não cotistas, tendo como réu correspondente a UERJ, seis recursos tiveram como fundamento o fato de o candidato não ter ganho em

\footnotetext{
${ }^{77}$ Esse julgamento ocorreu no dia 17 de abril de 2006, quando muitos candidatos que entraram por meio do sistema instituído pela Lei 3708/2001 já estavam, no mínimo, na metade do curso de graduação.
} 
primeira instância porque seria reprovado mesmo sem a lei de cotas. Outro teve como fundamento o fato de a sentença ter cassado a liminar concedida para o candidato se matricular. Outro fundamento, em quinze recursos, foi simplesmente o fato de o candidato não ter ganho em primeira instância.

Nos julgamentos da maioria desses recursos considerou-se que o candidato não teria passado mesmo sem a reserva de vagas. Em um, porém, o relator considerou as leis inconstitucionais e concedeu a segurança para o candidato se matricular. Em outro, o relator considerou que a candidata teria se classificado não fosse a reserva de vagas e que a Lei 3708/2001 foi declarada inconstitucional pelo Órgão Especial do Tribunal, merecendo provimento o recurso da candidata.

Nos casos em que a UERJ recorreu (porque a sentença concedeu liminar ou segurança para candidato se matricular), basicamente o fundamento do recurso foi que a universidade apenas estava cumprindo as leis e o edital e, em alguns casos, a instituição demonstrou que o candidato não teria sido aprovado mesmo sem a lei de cotas.

Nos julgamentos de dois recursos, o relator discorreu positivamente sobre as ações afirmativas e revogou liminar concedida ao candidato, provendo o recurso da UERJ. Em outros três, o relator considerou que o candidato não teria sido aprovado mesmo sem as leis de cotas. Em um julgado, o relator levantou incidente de inconstitucionalidade da Lei de 2001, e por isso suspendeu o julgamento. Em outro, o relator entendeu que as leis são inconstitucionais e ferem os princípios da razoabilidade e proporcionalidade, negando recurso da UERJ. Em um julgado, o relator considerou que a segurança deveria ser mantida para garantir a reserva da vaga, e dever-se-ia provar ao final que a candidata estaria classificada sem a existência das cotas, negando recurso da UERJ. Em outro, o relator avaliou que ações afirmativas são constitucionais, à luz do princípio da igualdade em sua vertente material, mas as leis de cotas em questão são desproporcionais, negando o recurso da UERJ. Por fim, em outro recurso o relator considerou que a liminar apenas reservava a vaga até que o mérito fosse julgado, e negou recurso da UERJ.

No caso específico em que tanto a candidata quanto a UERJ recorreram, a candidata, que teve segurança para se matricular, apelou para que a Lei 3254/2000 fosse também declarada inconstitucional com efeitos ex-tunc, e a UERJ apelou alegando que não poderia descumprir a Lei 3708/2001. No julgamento, o relator não conheceu do recurso da candidata e negou recurso da UERJ, alegando que se a Lei 4151/2003 diminuiu a porcentagem da reserva de vagas em relação à Lei 3708/2001, é porque o legislador reconheceu o excesso desta lei. 
Finalmente, na arguição de inconstitucionalidade 46/2006, julgada pelo Órgão Especial em 28 de agosto de 2006, tendo com relator o desembargador Ronald Valladares, o processo foi extinto sem julgamento do mérito em razão de as leis questionadas (3254 e 3708) terem perdido eficácia jurídica com o advento da Lei 4151/2003.

Tendo em vista o exposto, chega-se à resposta para a subpergunta 2: o argumento racial aparece mais do que o argumento social.

Sobre a hipótese inicialmente levantada para essa pergunta (houve mais ações judiciais de candidatos que não passaram no vestibular questionando a violação ao princípio da igualdade pelo uso de raça como forma de reserva de vagas), conclui-se que ela se confirma: dos candidatos não cotistas que recorreram, nenhum questionou a Lei 3254/2001 considerada de forma isolada, oito questionaram somente a Lei 3708/2001, e vinte e dois questionaram as Leis 3254 e 3708.

\section{3) Subpergunta $n^{\circ} 3$}

A Lei 3254/2003 esteve vigente de setembro de 2003 ao final de 2008 e foi, de alguma forma, questionada em quarenta e cinco dos cento e oito julgados analisados (não houve nenhum recurso no qual essa lei foi discutida junto com uma das outras duas leis estudadas). Foram doze julgados em 2005, dezoito em 2006, doze em 2007 e três em 2008.

Desses quarenta e cinco recursos, trinta e nove discutiram somente a exigência da comprovação de carência e seis discutiram a exigência de estudo na rede pública.

Dos trinta e nove que discutiram carência, em três julgados o autor foi a UERJ, que recorreu, basicamente, pois a sentença concedeu o direito de matrícula ao candidato pelo fato de o candidato ter "praticamente" ou "quase" cumprido o edital (não ter apresentado somente um documento ou estar próximo do limite de carência definido no edital).

Houve um julgado em que o autor foi candidato com deficiência que concorreu pelo sistema de cotas, mas não foi considerado carente e, por isso, não foi aprovado.

Cinco recursos foram impetrados por candidatos negros que concorreram pelo sistema de cotas, mas, ao final, foram desclassificados por não terem comprovado a situação de carência.

Três recursos tiveram candidatos carentes como autores. Basicamente, eles não foram considerados carentes de início, mas conseguiram comprovar nos autos do processo a situação de carência.

Vinte e seis candidatos concorreram pelo sistema de cotas, mas não foram classificados por não terem sido considerados carentes. Do total, apenas um candidato teve 
seu recurso provido, pois o valor que ultrapassava o limite estipulado pelo edital seria desprezível.

Por fim, houve um julgado que tratou de um candidato que não concorreu pelo sistema de cotas e ajuizou uma ação questionando a Lei 4151/2003.

Dos seis julgados que discutiram a exigência de estudo na rede pública no estado do Rio de Janeiro, em quatro os autores foram universidades que recorreram pois o candidato conseguiu o direito à matrícula em primeira instância (dois estudaram um ano em escola particular com bolsa integral, outros dois estudaram parte do ensino médio em outra unidade da federação).

Dois julgados tiveram como autor candidatos que concorreram pelo sistema de cotas, mas não estudaram na rede pública do Rio de Janeiro.

A partir de todo o exposto, responde-se à subpergunta 3 confirmando a hipótese inicialmente formulada: a maioria dos julgados que se debruçou sobre a Lei 4151/2003 concentrou-se majoritariamente na discussão do requisito da carência (e rede pública) e não adentrou na discussão das subcotas (raça e origem escolar). 


\section{CONCLUSÕES}

Esta dissertação teve como principal intenção investigar os argumentos utilizados pelos magistrados do Tribunal de Justiça do estado do Rio de Janeiro nos julgamentos de casos, de 2001 a 2008, que trataram das cotas instituídas nas universidades públicas daquele estado. Mais precisamente, pretendeu-se averiguar quais argumentos mais apareciam, e em que medida: os raciais ou os sociais.

Para poder realizar essa análise, um estudo sobre o princípio da igualdade fundamento maior da adoção de ações afirmativas - e sobre as próprias políticas de ações afirmativas fez-se necessário. Também foi imprescindível revelar a situação em que o negro se encontra no Brasil, justamente porque a ação afirmativa específica para esse grupo só pode ser justificada quando, antes, comprova-se que existe uma situação desigual entre os negros e os demais grupos de pessoas.

Em resumo, temos a concepção da igualdade formal, traduzida na máxima "todos são iguais perante a lei" (orientada pela consideração de um ser humano abstrato, e crucial para a abolição de privilégios à época); temos a concepção da igualdade material, que corresponde ao ideal de justiça social e distributiva (orientada pelo critério socioeconômico); e temos outra concepção de igualdade material, correspondente ao ideal de justiça como reconhecimento de identidades (orientada pelos critérios gênero, orientação sexual, idade, raça, etnia e demais critérios) (PIOVESAN, 2005, p. 47).

No caso do negro no Brasil, temos uma situação de escravidão no passado e desigualdade e discriminação racial no presente, aliada ao fato de a maioria dos pobres ser negra (ou a maioria dos negros ser pobre). Essa situação racial e social sobreposta, no entanto, relaciona-se a diferentes concepções de igualdade: a primeira concepção de igualdade formal parece estar resolvida no ordenamento jurídico brasileiro, mas é necessário, ainda, que as outras duas concepções de igualdade - aquelas orientadas por medidas de redistribuição de riquezas e de reconhecimento de identidades - sejam concretizadas:

Portanto, para promover os direitos fundamentais dos afrodescendentes é necessário combater nesses dois fronts - distribuição e reconhecimento - mas é certo que os avanços e retrocessos em cada um deles tendem a se refletir diretamente sobre o outro. É preciso corrigir a desigualdade econômica entre as raças no Brasil, ampliando o acesso dos negros ao mercado de trabalho, ao 
ensino superior e a outros bens socialmente valorizados, mas é essencial também promover os seus direitos culturais, valorizando seus símbolos e heróis e combatendo as ações que reforcem estigmas e preconceitos enraizados na sociedade. (SARMENTO, 2006, p. 141)

O princípio da igualdade previsto na Constituição Federal deve valer na prática em todas as suas acepções. Pelo fato de ser um princípio, sua importância no ordenamento jurídico é inquestionável como um fio condutor de todo o ordenamento infraconstitucional, das políticas do Poder Executivo e das decisões do Poder Judiciário.

Uma das formas de buscar a concretização desse princípio é por meio das ações afirmativas, que são, em linhas gerais, políticas urgentes, destinadas a grupos específicos, temporárias e positivas. Ou seja, são medidas que se diferenciam daquelas universalistas em sua definição e seus objetivos: por meio de um agir, visam alcançar mais rapidamente a igualdade de fato entre todos os grupos, e devem extinguir-se quando essa igualdade finalmente existir.

As cotas nas universidades públicas instituídas pela Assembleia Legislativa do estado do Rio de Janeiro representam uma das possibilidades de ação afirmativa. As diferentes leis que já existiram e foram revogadas simbolizam tentativas de buscar a igualdade, de remediar situações de injustiça. Melhor do que fazer nada é procurar sair de um debate abstrato e enxergar uma situação desigual, agindo para que ela não mais exista, ainda que seja necessário tentar algumas vezes até encontrar a melhor medida.

\footnotetext{
Para superar a imensa desigualdade racial no acesso à classe média, é necessário algum tipo de política baseada em raça. As cotas para vagas na universidade e no mercado de trabalho, que têm sido criadas em vários estados brasileiros, são, talvez, necessárias no início, visto que representam uma amostra de ação de verdade, mais do que pura retórica e debate acadêmico. (TELLES, 2003 p. 277) (grifos da autora)
}

As leis instituidoras das cotas foram questionadas no Poder Judiciário por diversos motivos. Houve autores não cotistas que não foram admitidos na universidade enquanto outros que concorreram pelo sistema de cotas foram: esses autores, em regra, argumentaram pela violação da lei ao princípio da constitucionalidade, da isonomia, da proporcionalidade, da razoabilidade, dentre outros. Houve autores que concorreram pela reserva de vagas, mas não foram admitidos: questionaram, nesses casos, o limite de renda definido no edital do processo seletivo e outros critérios utilizados nos editais ou na lei, como a exigência de estudo na rede pública do estado do Rio de Janeiro. 
Em uma avaliação geral dos julgados, pode-se afirmar que na maioria os desembargadores não discutem o mérito das políticas de ações afirmativas. Do total analisado, apenas $25 \%$ discute, em alguma medida, as cotas instituídas pelas leis estaduais ou as ações afirmativas em um sentido mais amplo. Em quase $29 \%$ os desembargadores decidem o caso sob o fundamento de que o candidato não obteve nota para ser aprovado mesmo que a reserva de vagas não existisse. Em 18,5\% dos julgados são discutidos aspectos processuais ou o cumprimento do edital. Em aproximadamente 5\% dos casos analisados, é considerado, de forma explícita, não ser papel do Judiciário valorar ou alterar os critérios estabelecidos nas leis ou nos editais das universidades. Em aproximadamente $8 \%$, os desembargadores decidiram com base nos fatos de que a demora no julgamento poderia gerar um dano irreparável e que existia uma alta probabilidade de o autor ter razão em sua demanda. Por fim, em 30,5\% dos casos, prevaleceu a discussão da situação de carência do candidato.

Foi curioso constatar que em nenhum julgado falou-se da necessidade de investir na educação de base para que as cotas não sejam necessárias. Curioso, pois este é um argumento que aparece bastante nos discursos contrários às ações afirmativas para ingresso nas universidades. Não foi surpresa, de outro lado, constatar que o argumento racial aparece mais do que o argumento social. Eventualmente esses argumentos, ou as leis que reservaram vagas para negros e para candidatos da rede pública, aparecem conjuntamente. Mas quando se observam as leis ou os argumentos de forma isolada, é o racial o mais questionado. Também não constituiu espanto, nos julgados que trataram da Lei 4151/2003, o fato de o recorte da carência ser questionado, e não as subcotas de raça e de rede pública.

Pequena parcela dos desembargadores faz uso da sua posição de julgador para decidir de forma contrária às ações afirmativas. Mesmo na hipótese de não apoiarem essas políticas, ou talvez especificamente as cotas, o fato é que se percebe nas decisões dos magistrados uma conformação jurídica, ou seja, a decisão fica adstrita aos aspectos mais internos, mais técnicos das leis. Com relação às duas primeiras leis, encontramos mais argumentos dos candidatos que passam pela violação de princípios constitucionais. Principalmente depois de a Lei 4151/2003 ter entrado em vigor, os próprios autores passam a recorrer ao Judiciário para questionar os requisitos formais da lei.

Especificamente com relação à questão racial, quando a Lei 3708/2001 estava em vigor, houve muitos questionamentos no que diz respeito à violação de princípios constitucionais (razoabilidade, isonomia etc.). A Lei 4151/2003 também institui cotas para negros, porém esses negros precisam, antes, ser carentes. E nesse momento, o perfil do 
questionador e do questionamento muda: em geral, o que se percebe são candidatos cotistas discutindo o critério da carência, e os não cotistas diminuindo a sua partipação no questionamento ao critério racial. É como se a raça fosse sumindo dos discursos, mas as cotas raciais, ainda que sobrepostas às sociais, permanecem existindo nas decisões judiciais.

Esse panorama exposto acima pode refletir uma dificuldade de discutir um assunto que ainda é polêmico no Brasil, pode refletir o pouco conhecimento que se tem sobre esse assunto, ou pode simplesmente indicar que os magistrados apenas julgaram dentro dos limites dos pedidos formulados na inicial das ações ajuizadas.

O fato é que a instituição de reserva de vagas nas universidades do Rio de Janeiro gerou um processo de procura do Tribunal desse estado. Não foi objetivo deste estudo analisar o papel do Poder Judiciário na definição de conceitos jurídicos ou na influência sobre leis elaboradas pelo Legislativo ou sobre políticas definidas pelo Executivo. O intuito, aqui, foi o de apenas trazer à luz como esse Poder conhece um assunto que ainda conquista seu espaço no debate científico-acadêmico e social, e decide as questões concretas, do dia-a-dia, das pessoas que são atingidas pelas políticas de ações afirmativas.

Ao trazer esses dados ao estudo acadêmico, novas perspectivas para a discussão das ações afirmativas podem ser apontadas. Aquilo que funciona e aquilo que não funciona pode ser levado em consideração nas novas tentativas de formular medidas que procurem, de forma mais rápida, alcançar uma situação de igualdade.

As ações afirmativas para ingresso nas universidades públicas, sejam por meio de cotas sociais, raciais, sistema de pontos, ou outra espécie, constituem uma tentativa concreta de realizar a justiça em seu aspecto de distribuição de riquezas (lembrando que as ações afirmativas, por si só, não possuem o condão de resolver todo o problema da pobreza, mas podem ser uma medida específica auxiliadora) e em seu aspecto de reconhecimento. Este último distingue-se claramente de medidas de caráter universalista, pois visam atingir determinados grupos que precisam ser reconhecidos nos padrões sociais, seja por meio da aparição na mídia, da ocupação dos espaços de poder, ou da paridade na participação nas instituições sociais. 


\section{REFERÊNCIAS}

A CINDERELA Negra. Veja, São Paulo, p. 66-67, 7 jul. 1993.

ALEXY, Robert. Teoría de los derechos fundamentales. Madrid: Centro de Estudios politicos y Constitucionales, 2007.

ANDERSON, James D. Race in American higher education: historical perspectives on current conditions. In: ALTABACH, Phillip G; LOMOTEY, Kofi; SMITH, William A. (org.). The racial crisis in American higher education: continuing challenges for the twenty-first century. New York: State University of New York Press, 2002.

ARAÚJO, Joel Zito. A negação do Brasil e o negro na história da telenovela brasileira. 3. ed. São Paulo: Senac, 2006, v 1.

ARENDT, Hannah. Origens do totalitarismo. São Paulo: Companhia das Letras, 1989. ARISTÓTELES. Ética a Nicômaco. São Paulo: Abril Cultural, 1973, p. 245-436.

BALL, Howard. The Bakke case: race, education and affirmative action. Kansas: University of Kansas Press, 2000.

BANDEIRA DE MELLO, CELSO ANTONIO. Curso de Direito Administrativo. $24^{\mathrm{a}}$ ed. São Paulo: Malheiros, 2007.

BARBOSA, Rui. Oração aos moços. 1920. Disponível em:

<http://www.ebooksbrasil.org/eLibris/aosmocos.html>. Acesso em: 24.08.2009.

BITTAR, Eduardo C. B. Anotações da Mesa de Abertura, do Seminário Percepções da Diferença, na Universidade de São Paulo, São Paulo, em dezembro de 2009.

BOBBIO, Norberto. Igualdade e liberdade. 5. Ed. São Paulo: Ediouro, 2002.

BONAVIDES, Paulo. O princípio da igualdade como limitação à atuação do Estado.

Revista Brasileira de Direito Constitucional, n. 2, São Paulo, p. 209-223, jul - dez 2003.

COSE, Elis. Pride and power. Shaking up "paradise": Brazil's vocal black-identity movement creates a new politics of race. Newsweek, New York, p. 42-48, 9 mar. 1998.

DWORKIN, Ronald. A virtude soberana: a teoria e a prática da igualdade. São Paulo: Martins Fontes, 2005.

Levando os direitos a sério. São Paulo: Martins Fontes, 2002.

Uma questão de princípio. São Paulo: Martins Fontes, 2000.

FEINBERG, Walter. On higher ground: education and the case for affirmative action.

New York: Teachers College, 1998.

FERNANDEZ, Encarnación. Igualdad y derechos humanos. Madrid: Tecnos, 2003. 
FRASER, Nancy. Reconhecimento sem ética?. Lua Nova, São Paulo, n. 70, p. 101-138, 2007.

; HONNETH, Axel. Redistribution or recognition? A political-philosofical exchange. London, New York: Verso, 2003.

FRISCHEISEN, Luiza Cristina Fonseca. Construção da igualdade e o sistema de justiça no Brasil: alguns caminhos e possibilidades. Rio de Janeiro: Editora Lumen Juris, 2007.

FRY, Peter. Ciência social e política "racial" no Brasil. Revista USP, n. 68, São Paulo, p. 180-187, dez-fev 2005-2006.

GOMES, Joaquim B. Barbosa. Ação afirmativa \& princípio constitucional da igualdade: o direito como instrumento de transformação social. A experiência dos EUA. Rio de Janeiro: Renovar, 2001.

O debate constitucional sobre as ações afirmativas. In: LOBATO, Fátima; SANTOS, Renato Emerson (Org.). Ações afirmativas: políticas públicas contra as desigualdades sociais. Rio de Janeiro: DP\&A, 2003.

GRAU, Eros Roberto. Ensaio e discurso sobre a interpretação/aplicação do direito. São Paulo: Malheiros, 2005.

GUIMARÃES, Antonio Sérgio Alfredo. Classes, raças e democracias. São Paulo: Editora 34, 2002.

GUIMARÃES, Luis Carlos Rocha; PIOVESAN, Flavia. Convenção sobre a Eliminação de Todas as Formas de Discriminação Racial. In: Centro de Estudos da Procuradoria Geral do Estado de São Paulo. Direitos Humanos: Construção da Liberdade e da Igualdade. São Paulo, 2000, p.353-368.

HASENBALG, Carlos. Desigualdades raciais no Brasil e na América Latina: as tímidas respostas ao racismo disfarçado. In: JELIN, Elizabeth; HERSHBERG, Eric (org.).

Construindo a democracia: direitos humanos, cidadania e sociedade na América Latina. São Paulo: Edusp, 2007.

HENRIQUES, Ricardo; CAVALLEIRO, Eliane. Educação e políticas públicas afirmativas: elementos da agenda do Ministério da Educação. In: SANTOS, Sales Augusto dos (org.). Ações afirmativas e combate ao racismo na América Latina. Brasília: Ministério da Educação, Secretaria de Educação Continuada, Alfabetização e Diversidade, 2005, p. 211-227.

IKAWA, Daniela. Ações afirmativas em universidades. Rio de Janeiro: Lúmen Júris, 2008 .

INSTITUTO BRASILEIRO DE GEOGRAFIA E ESTATÍSTICA (IBGE). Pesquisa Nacional por Amostra de Domicílios (2006). Disponível em: <http://www.ibge.gov.br>. Acesso em 15.12.2008.

INSTITUTO DE PESQUISA ECONÔMICA APLICADA. Políticas sociais: acompanhamento e análise. N. 15. Março de 2008. 
INSTITUTO DE PESQUISA ECONÔMICA APLICADA. Políticas sociais: acompanhamento e análise. N. 13. 2007.

JACCOUD, Luciana. O combate ao racismo e á desigualdade: o desafio das políticas públicas de promoção da igualdade racial. In: THEODORO, Mário (org.). As políticas públicas e a desigualdade racial no Brasil 120 anos após a abolição. Brasília: Ipea, 2008a, p. 131-166.

. Racismo e República: o debate sobre o branqueamento e a discriminação racial no Brasil. In: THEODORO, Mário (org.). As políticas públicas e a desigualdade racial no Brasil 120 anos após a abolição. Brasília: Ipea, 2008b, p. 45-64.

KAMEL, Ali. Não somos racistas: uma reação aos que querem nos transformar numa nação bicolor. Rio de Janeiro: Nova Fronteira, 2006.

LAFER, Celso. A internacionalização dos direitos humanos: constituição, racismo e relações internacionais. Barueri: Manole, 2005.

LOCKE, John. Segundo tratado sobre o governo. São Paulo: Abril Cultural, 1973, p. 37137.

LOPES, José Reinaldo Lima. Direitos sociais: teoria e prática. São Paulo: Método, 2006.

MASCARO, Alysson Leandro. Anotações da palestra "Exclusão social e racial e perspectivas de ação", ministrada no Seminário Percepções da Diferença, na Universidade de São Paulo, São Paulo, em dezembro de 2009.

MELLO, Marco Aurélio de. Óptica constitucional: A igualdade e as ações afirmativas. Direito e Sociedade, Curitiba, v. 2, n. 2, p.1-14, jul./dez. 2001.

MONTESQUIEU. Do espírito das leis. São Paulo: Abril Cultural, 1973, p. 27-547.

MUNANGA, Kabelenge. Anotações da palestra "Os direitos humanos no contexto da diversidade cultural”, ministrada no Seminário Percepções da Diferença, na Universidade de São Paulo, São Paulo, em dezembro de 2009.

. Entrevista concedida para a Revista Fórum. Nosso racismo é um crime perfeito.18 de Agosto de 2009. Disponível em:

<http://www.revistaforum.com.br/sitefinal/EdicaoNoticiaIntegra.asp?id_artigo=7378>. Acesso em 23.11.2009.

. Políticas de ação afirmativa em benefício da população negra no Brasil: um ponto de vista em defesa das cotas. In: DURHAM, Eunice R.; BORI, Carolina M. (orgs.).

Seminário O negro no Ensino Superior. São Paulo: Núcleo de Pesquisas sobre Ensino Superior, 2002, p. 124-135.

NICKEL, James W. Discrimination and morally relevant characteristics. In: CAHN, Steven M (ed.). The affirmative action debate. New York, London: Routledge, 2002, p. 3-4. 
NOVAES, Adelina de Oliveira et. al.. As bases eletrônicas de jurisprudência nos tribunais de São Paulo. Apresentação de Trabalho no V Congresso da Associação Brasileira de Ensino do Direito. 2007.

ORGANIZAÇÃO DAS NAÇÕES UNIDAS (ONU). Convenção internacional sobre a eliminação de todas as formas de discriminação racial. Disponível em: $<$ http://www.dhnet.org.br/direitos/sip/onu/discrimina/lex81.htm>. Acesso em: 25.12.2008.

ORGANIZAÇÃO DAS NAÇÕES UNIDAS (ONU). Declaração Universal dos Direitos Humanos. Disponível em: 〈http://www.dhnet.org.br/direitos/deconu/textos/integra.htm>. Acesso em: 25.12.2008.

ORWELL, George. A revolução dos bichos. São Paulo: Abril Cultural, 1982.

OSÓRIO, Rafael Guerreiro. Desigualdade racial e mobilidade social no Brasil: um balanço das teorias. In: THEODORO, Mário (org.). As políticas públicas e a desigualdade racial no Brasil 120 anos após a abolição. Brasília: Ipea, 2008, p. 65-95.

PIOVESAN, Flavia. Ações afirmativas da perspectiva dos direitos humanos. Cadernos de Pesquisa, n. 124, v. 35, São Paulo, p. 43-55, jan-abr 2005.

RACISMO. Folha de São Paulo, São Paulo, 23 nov. 2008, Especial, pp 1-12.

ROUSSEAU, Jean-Jacques. Discurso sobre a origem e os fundamentos da desigualdade entre os homens. São Paulo: Abril Cultural, 1973, p. 207-326.

SALOMÃO FILHO, Calixto. Anotações da Mesa de Abertura, do Seminário Percepções da Diferença, na Universidade de São Paulo, São Paulo, em dezembro de 2009a.

. Anotações da palestra "Exclusão social e racial e perspectivas de ação", ministrada no Seminário Percepções da Diferença, na Universidade de São Paulo, São Paulo, em dezembro de 2009.

SANTOS, Boaventura de Sousa. Uma concepção multicultural de direitos humanos. Lua Nova, São Paulo, v. 39, p.105-124, 1997.

SANTOS, Jocélio Teles dos; QUEIROZ, Delcele Mascarenhas. Vestibular com cotas: análise em uma instituição pública federal. Revista USP, n. 68, São Paulo, p. 58-75, dezfev 2005-2006.

SARMENTO, Daniel. Livres e iguais. Rio de Janeiro: Lumen Juris, 2006.

SEGATO, Rita Laura. Cotas: por que não reagimos?. Revista USP, n. 68, São Paulo, p. 76-87, dez-fev 2005-2006.

SILVA, José Afonso da. Curso de direito constitucional positivo. $18^{\mathrm{a}}$ ed. São Paulo: Malheiros, 2000.

SILVA, Paulo Vinícius Baptista da; ROSEMBERG, Fúlvia. Brasil: lugares de negros e brancos na mídia. In: VAN DIJK, Teun A. (org.). Racismo e discurso na América Latina. São Paulo: Conexto, 2008, p. 73-117. 
SINGER, Peter. Ética prática. São Paulo: Martins Fontes, 2002.

TELLES, Edward. Racismo à brasileira: uma nova perspectiva sociológica. Rio de Janeiro: Relume Dumará, 2003.

THEODORO, Mário. À guisa de conclusão: o difícil debate da questão racial e das políticas públicas de combate à desigualdade e à discriminação racial no Brasil. In: THEODORO, Mário (org.). As políticas públicas e a desigualdade racial no Brasil 120 anos após a abolição. Brasília: Ipea, 2008, p. 167-176.

VAN DIJK, Teun A. Introdução. In: VAN DIJK, Teun A. (org.). Racismo e discurso na América Latina. São Paulo: Conexto, 2008, p. 11-24.

VIEIRA JUNIOR, Ronaldo Jorge A. Rumo ao multiculturalismo: a adoção compulsória de ações afirmativas pelo Estado brasileiro como reparação dos danos atuais sofridos pela população negra. In: SANTOS, Sales Augusto dos (org.). Ações afirmativas e combate ao racismo na América Latina. Brasília: Ministério da Educação, Secretaria de Educação Continuada, Alfabetização e Diversidade, 2005, p. 81-100.

WEDDERBURN, Carlos Moore. Do marco histórico das políticas públicas de ação afirmativa. In: SANTOS, Sales Augusto dos (org.). Ações afirmativas e combate ao racismo na América Latina. Brasília: Ministério da Educação, Secretaria de Educação Continuada, Alfabetização e Diversidade, 2005, p. 313-341.

ZEGARRA, Mónica Carrillo. Ações afirmativas e afrodescententes na América Latina: análise de discursos, contra-discursos e estraégias. In: SANTOS, Sales Augusto dos (org.). Ações afirmativas e combate ao racismo na América Latina. Brasília: Ministério da Educação, Secretaria de Educação Continuada, Alfabetização e Diversidade, 2005, p. 343 365 .

\section{Legislação}

BRASIL. Constituição (1988). Constituição da República Federativa do Brasil. Brasília, DF: Senado Federal, 1988.

BRASIL. Plano Nacional de Direitos Humanos. Decreto 1904, de 13 de maio de 1996. Disponível em : <http://www.planalto.gov.br/ccivil_03/decreto/D1904.htm>. Acesso em: 11.07.2009.

BRASIL. Programa Nacional de Direitos Humanos. Decreto 4229, de 13 de maio de 2002. Disponível em :

<http://www.planalto.gov.br/ccivil_03/decreto/2002/D4229.htm\#8>. Acesso em:

11.07.2009.

ESTADOS UNIDOS DA AMÉRICA. Ordem Executiva 11246. 24 de setembro de 1965. Disponível em: <http://www.dol.gov/ofccp/regs/statutes/eo11246.htm>. Acesso em: 27.12.2009. 
ESTADOS UNIDOS DA AMÉRICA. Ordem Executiva n. 10925. 6 de março de 1961. Disponível em <http://eeoc.gov/eeoc/history/35th/thelaw/eo-10925.html>. Acesso em: 01.12.2008.

ESTADOS UNIDOS DA AMÉRICA. Public Law 88-352 (Lei de Direitos Civis). 2 de julho de 1964. Disponível em:

<http://uspolitics.about.com/od/usgovernment/1/bl_civil_rights_act_7.htm>. Acesso em: 01.12.2008.

ORGANIZAÇÃO DAS NAÇÕES UNIDAS. Declaração Universal dos Direitos Humanos. 10 de dezembro de 1948. Disponível em:

<http://www.mj.gov.br/sedh/ct/legis_intern/ddh_bib_inter_universal.htm>. Acesso em: 13.01.2010.

ORGANIZAÇÃO DAS NAÇÕES UNIDAS. Convenção sobre a Eliminação de Todas as Formas de Discriminação Racial. 21 de dezembro de 1965. Disponível em:

<http://www.pge.sp.gov.br/centrodeestudos/bibliotecavirtual/instrumentos/discriraci.htm>. Acesso em: 13.01.2010.

ORGANIZAÇÃO DAS NAÇÕES UNIDAS. III Conferência Mundial de Combate ao Racismo, Discriminação Racial, Xenofobia e Intolerância Correlata. 31 de agosto a 3 de setembro de 2001. Disponível em:

<http://www.inesc.org.br/biblioteca/legislacao/Declaracao_Durban.pdf > . Acesso em: 13.01.2010.

RIO DE JANEIRO. Lei n. 3524, de 28 de dezembro de 2000. Disponível em: <http://www.alerj.rj.gov.br>. Acesso em: 10.10.2008.

RIO DE JANEIRO. Lei n. 3708, de 9 de novembro de 2001. Disponível em: <http://www.alerj.rj.gov.br>. Acesso em: 10.10.2008.

RIO DE JANEIRO. Lei n. 4151, de 4 de setembro de 2003. Disponível em: <http://www.alerj.rj.gov.br>. Acesso em: 10.10.2008.

RIO DE JANEIRO. Lei n. 5074, de 17 de julho de 2007. Disponível em: <http://www.alerj.rj.gov.br>. Acesso em: 10.10.2008.

RIO DE JANEIRO. Lei n. 5346, de 11 de dezembro de 2008. Disponível em: <http://www.alerj.rj.gov.br>. Acesso em: 23.12.2008.

\section{Julgados}

BRASIL. Supremo Tribunal Federal. Ação Direta de Inconstitucionalidade n. 2858.

Relator Ministro Carlos Velloso. Disponível em:

<http://www.stf.jus.br/portal/peticaoInicial/verPeticaoInicial.asp?base=ADIN\&s1=2858\& processo=2858 $>$. Acesso em: 22.11.2008. 
BRASIL. Supremo Tribunal Federal. Ação Direta de Inconstitucionalidade n. 3197. Confederação Nacional dos Estabelecimentos de Ensino e Governadora do Estado do Rio de Janeiro e Assembleia Legislativa do Estado do Rio de Janeiro. Relator Sepúlveda Pertence. Aguardando julgamento. Disponível em:

$<$ http://www.stf.jus.br/portal/peticaoInicial/verPeticaoInicial.asp?base=ADIN\&s1=2858\& processo $=2858>$. Acesso em: 22.11.2008.

CONECTAS DIREITOS HUMANOS. Amicus Curiae na Ação Direta de Inconstitucionalidade n. 3197. 18.05.2004. Disponível em:

<http://www.conectas.org/stfemfoco/home/processos/amicus>. Acesso em: 22.11.2008.

ESTADOS UNIDOS DA AMÉRICA. Suprema Corte. Regents of the University of California versus Bakke. 438 US 265. J. 28 jun. 1978. Disponível em:

<http://supreme.justia.com/us/438/265/case.html>. Acesso em: 12.01.2009.

RIO DE JANEIRO. Tribunal de Justiça do Estado do Rio de Janeiro. Órgão Especial. Ação Direta de Inconstitucionalidade n. 9. Relator: Desembargador Sérgio Cavalieri Filho. J. 18 nov 2009. Disponível em: <www.tj.rj.gov.br>. Acesso em: 13.01.2010.

RIO DE JANEIRO. Tribunal de Justiça do Estado do Rio de Janeiro. Órgão Especial. Ação Direta de Inconstitucionalidade n. 9. Relator: Desembargador José Carlos S. Murta Ribeiro. J. 25 mai 2009. Disponível em: <www.tj.rj.gov.br>. Acesso em: 13.01.2010.

RIO DE JANEIRO. Tribunal de Justiça do Estado do Rio de Janeiro. $5^{\text {a }}$ Câmara Cível. Agravo de Instrumento n. 200300203810. Relator: Desembargador Antonio Cesar Siqueira. J. 5 ago 2008. Disponível em: <www.tj.rj.gov.br〉. Acesso em: 05.10.2008.

RIO DE JANEIRO. Tribunal de Justiça do Estado do Rio de Janeiro. $1^{\text {a }}$ Câmara Cível. Agravo de Instrumento n. 200700210157. Relatora: Desembargadora Maria Augusta Vaz M. De Figueiredo. J. 4 set 2007. Disponível em: <www.tj.rj.gov.br〉. Acesso em: 05.10.2008.

RIO DE JANEIRO. Tribunal de Justiça do Estado do Rio de Janeiro. $16^{\text {a }}$ Câmara Cível. Agravo de Instrumento n. 200700202373. Relator: Desembargador Orlando Secco. J. 5 jun 2007. Disponível em: <www.tj.rj.gov.br>. Acesso em: 05.10.2008.

RIO DE JANEIRO. Tribunal de Justiça do Estado do Rio de Janeiro. $20^{\text {a }}$ Câmara Cível. Agravo de Instrumento n. 200700211039. Relator: Desembargador Marco Antonio Ibrahim. J. 9 mai 2007. Disponível em: <www.tj.rj.gov.br>. Acesso em: 05.10.2008.

RIO DE JANEIRO. Tribunal de Justiça do Estado do Rio de Janeiro. $18^{a}$ Câmara Cível. Agravo de Instrumento n. 200300206264. Relator: Desembargador Ferdinaldo Nascimento. J. 7 fev 2006. Disponível em: <www.tj.rj.gov.br〉. Acesso em: 23.12.2008.

RIO DE JANEIRO. Tribunal de Justiça do Estado do Rio de Janeiro. $2^{a}$ Câmara Cível. Agravo de Instrumento n. 200400222075. Relator: Desembargador José Carlos Varanda. J. 23 ago 2005. Disponível em: <www.tj.rj.gov.br>. Acesso em: 05.10.2008.

RIO DE JANEIRO. Tribunal de Justiça do Estado do Rio de Janeiro. 10 Câmara Cível. Agravo de Instrumento n. 200300206611. Relator: Desembargador José Carlos Varanda. J. 4 mai 2004. Disponível em: <www.tj.rj.gov.br>. Acesso em: 05.10.2008. 
RIO DE JANEIRO. Tribunal de Justiça do Estado do Rio de Janeiro. $6^{\text {a }}$ Câmara Cível. Agravo de Instrumento n. 200300205825. Relator: Desembargador Nagib Slaibi. J. 17 mar 2004. Disponível em: <www.tj.rj.gov.br>. Acesso em: 05.10.2008.

RIO DE JANEIRO. Tribunal de Justiça do Estado do Rio de Janeiro. 11a Câmara Cível. Agravo de Instrumento n. 200300207948. Relator: Desembargador Claudio de Mello Tavares. J. 14 jan 2004. Disponível em: 〈www.tj.rj.gov.br>. Acesso em: 23.12.2008.

RIO DE JANEIRO. Tribunal de Justiça do Estado do Rio de Janeiro. $1^{\text {a }}$ Câmara Cível. Agravo de Instrumento n. 200300204351. Relator: Desembargador Paulo Sérgio Fabião. J. 28 out 2003. Disponível em: <www.tj.rj.gov.br>. Acesso em: 05.10.2008.

RIO DE JANEIRO. Tribunal de Justiça do Estado do Rio de Janeiro. $11^{\text {a }}$ Câmara Cível. Agravo de Instrumento n. 200300205602. Relator: Desembargador Claudio de Mello Tavares. J. 16 out 2003. Disponível em: <www.tj.rj.gov.br〉. Acesso em: 05.10.2008.

RIO DE JANEIRO. Tribunal de Justiça do Estado do Rio de Janeiro. 11a Câmara Cível. Agravo de Instrumento n. 200300205670. Relator: Desembargador Claudio de Mello Tavares. J. 16 out 2003. Disponível em: 〈www.tj.rj.gov.br〉. Acesso em: 23.12.2008.

RIO DE JANEIRO. Tribunal de Justiça do Estado do Rio de Janeiro. 11a Câmara Cível. Agravo de Instrumento n. 200300207589. Relator: Desembargador Claudio de Mello Tavares. J. 16 out 2003. Disponível em: 〈www.tj.rj.gov.br〉. Acesso em: 23.12.2008.

RIO DE JANEIRO. Tribunal de Justiça do Estado do Rio de Janeiro. 11 a Câmara Cível. Agravo de Instrumento n. 200300204409. Relator: Desembargador Claudio de Mello Tavares. J. 16 out 2003. Disponível em: 〈www.tj.rj.gov.br〉. Acesso em: 05.10.2008.

RIO DE JANEIRO. Tribunal de Justiça do Estado do Rio de Janeiro. $2^{\text {a }}$ Câmara Cível. Agravo de Instrumento n. 200300206428. Relatora: Desembargadora Elizabete Filizzola Assunção. J. $1^{\text {º }}$ out 2003. Disponível em: <www.tj.rj.gov.br>. Acesso em: 05.10.2008.

RIO DE JANEIRO. Tribunal de Justiça do Estado do Rio de Janeiro. $2^{\mathrm{a}}$ Câmara Cível. Agravo de Instrumento n. 200300206236. Relatora: Desembargadora Elizabete Filizzola Assunção. J. 24 set 2003. Disponível em: <www.tj.rj.gov.br>. Acesso em: 05.10.2008.

RIO DE JANEIRO. Tribunal de Justiça do Estado do Rio de Janeiro. $14^{a}$ Câmara Cível. Agravo de Instrumento n. 200300206260. Relatora: Desembargadora Maria Christina Louchard de Góes. J. 24 set 2003. Disponível em: 〈www.tj.rj.gov.br〉. Acesso em: 05.10.2008.

RIO DE JANEIRO. Tribunal de Justiça do Estado do Rio de Janeiro. $14^{\text {a }}$ Câmara Cível. Agravo de Instrumento n. 200300206411. Relatora: Desembargadora Maria Christina Louchard de Góes. J. 23 set 2003. Disponível em: <www.tj.rj.gov.br〉. Acesso em: 23.12.2008.

RIO DE JANEIRO. Tribunal de Justiça do Estado do Rio de Janeiro. $5^{\text {a }}$ Câmara Cível. Agravo de Instrumento n. 200300206540. Relator: Desembargador Antonio Cesar Siqueira. J. 19 ago 2003. Disponível em: <www.tj.rj.gov.br>. Acesso em: 05.10.2008. 
RIO DE JANEIRO. Tribunal de Justiça do Estado do Rio de Janeiro. $1^{\text {a }}$ Câmara Cível. Agravo de Instrumento n. 200300204892. Relator: Desembargador Benito Ferolla. J. 12 ago 2003. Disponível em: <www.tj.rj.gov.br>. Acesso em: 05.10.2008.

RIO DE JANEIRO. Tribunal de Justiça do Estado do Rio de Janeiro. $5^{\text {a }}$ Câmara Cível. Agravo de Instrumento n. 200300203814. Relator: Desembargador Carlos Ferrari. J. 12 ago 2003. Disponível em: <www.tj.rj.gov.br>. Acesso em: 05.10.2008.

RIO DE JANEIRO. Tribunal de Justiça do Estado do Rio de Janeiro. $2^{\text {a }}$ Câmara Cível. Agravo de Instrumento n. 200300203741. Relatora: Desembargadora Leila Mariano. J. 6 ago 2003. Disponível em: <www.tj.rj.gov.br>. Acesso em: 05.10.2008.

RIO DE JANEIRO. Tribunal de Justiça do Estado do Rio de Janeiro. $5^{\text {a }}$ Câmara Cível. Agravo de Instrumento n. 20030024515. Relator: Desembargador Antonio Cesar Siqueira. J. 5 ago 2003. Disponível em: <www.tj.rj.gov.br>. Acesso em: 23.12.2008.

RIO DE JANEIRO. Tribunal de Justiça do Estado do Rio de Janeiro. 18a Câmara Cível. Agravo de Instrumento n. 200300205632. Relatora: Desembargadora Célia Maria Vidal Meliga Pessoa. J. 1º jul 2003. Disponível em: <www.tj.rj.gov.br>. Acesso em: 05.10.2008.

RIO DE JANEIRO. Tribunal de Justiça do Estado do Rio de Janeiro. $2^{\mathrm{a}}$ Câmara Cível. Agravo de Instrumento n. 200300204944. Relator: Desembargador Jessé Torres. J. 18 jun 2003. Disponível em: <www.tj.rj.gov.br>. Acesso em: 05.10.2008.

RIO DE JANEIRO. Tribunal de Justiça do Estado do Rio de Janeiro. $13^{\text {a }}$ Câmara Cível. Agravo de Instrumento n. 200300204668. Relator: Desembargador Antonio José Azevedo Pinto. J. 11 jun 2003. Disponível em: <www.tj.rj.gov.br>. Acesso em: 23.12.2008.

RIO DE JANEIRO. Tribunal de Justiça do Estado do Rio de Janeiro. $2^{\text {a }}$ Câmara Cível. Agravo de Instrumento n. 200300205695. Relator: Desembargador Jessé Torres. J. 11 jun 2003. Disponível em: <www.tj.rj.gov.br>. Acesso em: 05.10.2008.

RIO DE JANEIRO. Tribunal de Justiça do Estado do Rio de Janeiro. 15ª Câmara Cível. Agravo de Instrumento n. 200300204790. Relator: Desembargador Sergio Lucio de Oliveira e Cruz. J. 11 jun 2003. Disponível em: <www.tj.rj.gov.br>. Acesso em: 05.10.2008.

RIO DE JANEIRO. Tribunal de Justiça do Estado do Rio de Janeiro. $16^{\mathrm{a}}$ Câmara Cível. Agravo de Instrumento n. 200300204775. Relator: Desembargador Miguel Ângelo Barros. J. 3 jun 2003. Disponível em: <www.tj.rj.gov.br>. Acesso em: 05.10.2008.

RIO DE JANEIRO. Tribunal de Justiça do Estado do Rio de Janeiro. $2^{\text {a }}$ Câmara Cível. Agravo de Instrumento n. 200300204073. Relator: Desembargador Jessé Torres. J. 21 mai 2003. Disponível em: <www.tj.rj.gov.br>. Acesso em: 05.10.2008.

RIO DE JANEIRO. Tribunal de Justiça do Estado do Rio de Janeiro. 17ª Câmara Cível. Agravo de Instrumento n. 200300127536. Relator: Desembargador Henrique Carlos de Andrade Figueira. J. 30 abr 2003. Disponível em: 〈www.tj.rj.gov.br〉. Acesso em: 05.10.2008.

RIO DE JANEIRO. Tribunal de Justiça do Estado do Rio de Janeiro. $17^{\text {a }}$ Câmara Cível. Agravo de Instrumento n. 200300203536. Relator: Desembargador Henrique Carlos de 
Andrade Figueira. J. 30 abr 2003. Disponível em: 〈www.tj.rj.gov.br〉. Acesso em: 05.10.2008.

RIO DE JANEIRO. Tribunal de Justiça do Estado do Rio de Janeiro. $7^{\text {a }}$ Câmara Cível. Agravo Inominado n. 200400101512. Relator: Desembargador Ricardo Rodrigues Cardozo. J. 31 mai 2005. Disponível em: <www.tj.rj.gov.br>. Acesso em: 05.10.2008.

RIO DE JANEIRO. Tribunal de Justiça do Estado do Rio de Janeiro. $17^{a}$ Câmara Cível. Agravo Interno no Agravo de Instrumento n. 200800209800. Relator: Desembargador Antônio Iloízio Barros Bastos. J. 30 abr 2008. Disponível em: <www.tj.rj.gov.br>. Acesso em: 05.10.2008.

RIO DE JANEIRO. Tribunal de Justiça do Estado do Rio de Janeiro. $3^{\text {a }}$ Câmara Cível. Agravo Regimental n. 29389 Relator: Desembargador Antonio Eduardo F. Duarte. J. 22 nov 2007. Disponível em: <www.tj.rj.gov.br>. Acesso em: 05.10.2008.

RIO DE JANEIRO. Tribunal de Justiça do Estado do Rio de Janeiro. $18^{a}$ Câmara Cível. Apelação 14377. Relator: Desembargador Rogério de Oliveira Souza. J. 30 set 2008. Disponível em: <www.tj.rj.gov.br>. Acesso em: 23.12.2008.

RIO DE JANEIRO. Tribunal de Justiça do Estado do Rio de Janeiro. 10ª Câmara Cível. pelação n. 200700166595. Relator: Desembargador Roberto Ribeiro. J. 13 fev 2008. Disponível em: <www.tj.rj.gov.br〉. Acesso em: 05.10.2008.

RIO DE JANEIRO. Tribunal de Justiça do Estado do Rio de Janeiro. 17 $7^{\text {a }}$ Camara Cível. Apelação 200700130389. Relator: Desembargador Elton M. C. Leme. J. 17 out 2007. Disponível em: <www.tj.rj.gov.br>. Acesso em: 23.12.2008.

RIO DE JANEIRO. Tribunal de Justiça do Estado do Rio de Janeiro. 16ª Câmara Cível. Apelação 200700140955. Relator: Desembargador Pedro Raguenet. J. 16 out 2007. Disponível em: <www.tj.rj.gov.br>. Acesso em: 23.12.2008.

RIO DE JANEIRO. Tribunal de Justiça do Estado do Rio de Janeiro. $18^{a}$ Câmara Cível. Apelação 48153. Relatora: Desembargadora Célia Maria Vidal Meliga Pessoa. J. 27 set 2007. Disponível em: <www.tj.rj.gov.br>. Acesso em: 23.12.2008.

RIO DE JANEIRO. Tribunal de Justiça do Estado do Rio de Janeiro. $9^{a}$ Câmara Cível. Apelação 2331. Relator: Desembargador Joaquim Alves de Brito. J. 28 ago 2007. Disponível em: <www.tj.rj.gov.br>. Acesso em: 23.12.2008.

RIO DE JANEIRO. Tribunal de Justiça do Estado do Rio de Janeiro. $6^{\text {a }}$ Câmara Cível. Apelação 200600155203. Relator: Desembargador Francisco de Assis Pessanha. J. $1^{\circ}$ ago 2007. Disponível em: <www.tj.rj.gov.br>. Acesso em: 23.12.2008.

RIO DE JANEIRO. Tribunal de Justiça do Estado do Rio de Janeiro. $6^{\text {a }}$ Câmara Cível. Apelação n. 200600169833. Relator: Desembargador Marco Aurélio dos Santos Fróes. J. 27 jun 2007. Disponível em: <www.tj.rj.gov.br>. Acesso em: 23.12.2008.

RIO DE JANEIRO. Tribunal de Justiça do Estado do Rio de Janeiro. $10^{\mathrm{a}}$ Câmara Cível. Apelação n. 200600138616. Relator: Desembargador José Carlos Varanda. J. 13 jun 2007. Disponível em: <www.tj.rj.gov.br>. Acesso em: 05.10.2008. 
RIO DE JANEIRO. Tribunal de Justiça do Estado do Rio de Janeiro. $6^{\text {a }}$ Câmara Cível. Apelação 20070010817. Relator: Desembargador Marco Aurélio dos Santos Fróes. J. 9 mai 2007. Disponível em: <www.tj.rj.gov.br>. Acesso em: 23.12.2008.

RIO DE JANEIRO. Tribunal de Justiça do Estado do Rio de Janeiro. $7^{\text {a }}$ Câmara Cível. Apelação n. 200500120679. Relator: Desembargador Bernardo Moreira Garcez Neto. J. 17 jan 2007. Disponível em: <www.tj.rj.gov.br>. Acesso em: 23.12.2008.

RIO DE JANEIRO. Tribunal de Justiça do Estado do Rio de Janeiro. $6^{\text {a }}$ Câmara Cível. Apelação n. 200600122174. Relator: Desembargador Ronaldo Álvaro Martins. J. 20 dez 2006. Disponível em: <www.tj.rj.gov.br>. Acesso em: 05.10.2008.

RIO DE JANEIRO. Tribunal de Justiça do Estado do Rio de Janeiro. 17ª Câmara Cível. Apelação 50334. Relator: Desembargador Rogério de Oliveira Souza. J. 13 dez 2006. Disponível em: <www.tj.rj.gov.br>. Acesso em: 23.12.2008.

RIO DE JANEIRO. Tribunal de Justiça do Estado do Rio de Janeiro. $1^{\text {a }}$ Câmara Cível. Apelação 200600144249. Relatora: Desembargadora Vera Maria Van Hombeeck. J. 21 nov 2006. Disponível em: <www.tj.rj.gov.br>. Acesso em: 23.12.2008.

RIO DE JANEIRO. Tribunal de Justiça do Estado do Rio de Janeiro. $18^{a}$ Câmara Cível. Apelação n. 200600143650. Relator: Desembargador Luiz Fernando de Andrade Pinto. J. 21 nov 2006. Disponível em: <www.tj.rj.gov.br>. Acesso em: 05.10.2008.

RIO DE JANEIRO. Tribunal de Justiça do Estado do Rio de Janeiro. $5^{\text {a }}$ Câmara Cível. Apelação n. 200600151764. Relator: Desembargador Paulo Gustavo Horta. J. 31 out 2006. Disponível em: <www.tj.rj.gov.br>. Acesso em: 05.10.2008.

RIO DE JANEIRO. Tribunal de Justiça do Estado do Rio de Janeiro. $8^{\text {a }}$ Câmara Cível. Apelação n. 200500141040. Relatora: Desembargadora Letícia Sardas. J. 24 out 2006. Disponível em: <www.tj.rj.gov.br>. Acesso em: 05.10.2008.

RIO DE JANEIRO. Tribunal de Justiça do Estado do Rio de Janeiro. $11^{\text {a }}$ Câmara Cível. Apelação n. 200600132946. Relator: Desembargador Paulo Sérgio Prestes dos Santos. J. 13 set 2006. Disponível em: <www.tj.rj.gov.br>. Acesso em: 23.12.2008.

RIO DE JANEIRO. Tribunal de Justiça do Estado do Rio de Janeiro. $11^{a}$ Câmara Cível. Apelação 28622. Relator: Desembargador Luiz Eduardo Rabello. J. 7 jun 2006. Disponível em: <www.tj.rj.gov.br>. Acesso em: 23.12.2008.

RIO DE JANEIRO. Tribunal de Justiça do Estado do Rio de Janeiro. $2^{\mathrm{a}}$ Câmara Cível. Apelação n. 200600122089. Relator: Desembargador Jessé Torres. J. 18 mai 2006. Disponível em: <www.tj.rj.gov.br>. Acesso em: 05.10.2008.

RIO DE JANEIRO. Tribunal de Justiça do Estado do Rio de Janeiro. $8^{a}$ Câmara Cível. Apelação n. 200500141489. Relatora: Desembargadora Letícia Sardas. J. 16 mai 2006. Disponível em: <www.tj.rj.gov.br>. Acesso em: 05.10.2008.

RIO DE JANEIRO. Tribunal de Justiça do Estado do Rio de Janeiro. $16^{\mathrm{a}}$ Câmara Cível. Apelação n. 2626805. Relator: Desembargador Mário Robert Mannheimer. J. 16 mai 2006. Disponível em: <www.tj.rj.gov.br>. Acesso em: 23.12.2008. 
RIO DE JANEIRO. Tribunal de Justiça do Estado do Rio de Janeiro. $11^{a}$ Câmara Cível. Apelação 12530. Relator: Desembargador Otávio Rodrigues. J. 10 mai 2006. Disponível em: <www.tj.rj.gov.br>. Acesso em: 23.12.2008.

RIO DE JANEIRO. Tribunal de Justiça do Estado do Rio de Janeiro. $17^{\text {a }}$ Câmara Cível. Apelação n. 200500149966. Relator: Desembargador Camilo Ribeiro Rulière. J. 26 abr 2006. Disponível em: <www.tj.rj.gov.br>. Acesso em: 05.10.2008.

RIO DE JANEIRO. Tribunal de Justiça do Estado do Rio de Janeiro. $16^{\text {a }}$ Câmara Cível. Apelação n. 3008105. Relator: Desembargador Mário Robert Mannheimer. J. 25 abr 2006. Disponível em: <www.tj.rj.gov.br>. Acesso em: 23.12.2008.

RIO DE JANEIRO. Tribunal de Justiça do Estado do Rio de Janeiro. $6^{\text {a }}$ Câmara Cível. Apelação n. 200600100328. Relator: Desembargador Ronaldo Lopes Martins. J. 18 abr 2006. Disponível em: <www.tj.rj.gov.br>. Acesso em: 05.10.2008.

RIO DE JANEIRO. Tribunal de Justiça do Estado do Rio de Janeiro. $13^{\mathrm{a}}$ Câmara Cível. Apelação n. 200500141492. Relator: Desembargador José de Samuel Marques. J. 5 abr 2006. Disponível em: <www.tj.rj.gov.br>. Acesso em: 05.10.2008.

RIO DE JANEIRO. Tribunal de Justiça do Estado do Rio de Janeiro. $7^{\text {a }}$ Câmara Cível. Apelação n. 20040130658. Relator: Desembargador José Mota Filho. J. 7 mar 2006. Disponível em: <www.tj.rj.gov.br>. Acesso em: 05.10.2008.

RIO DE JANEIRO. Tribunal de Justiça do Estado do Rio de Janeiro. $7^{\text {a }}$ Câmara Cível. Apelação n. 200500123324. Relator: Desembargador Carlos C. Lavigne de Lemos. J. 14 fev 2006. Disponível em: <www.tj.rj.gov.br>. Acesso em: 05.10.2008.

RIO DE JANEIRO. Tribunal de Justiça do Estado do Rio de Janeiro. $8^{\text {a }}$ Câmara Cível. Apelação n. 200500123440. Relatora: Desembargadora Odete Knaack de Souza. J. 24 jan 2006. Disponível em: <www.tj.rj.gov.br>. Acesso em: 05.10.2008.

RIO DE JANEIRO. Tribunal de Justiça do Estado do Rio de Janeiro. 10ª Câmara Cível. Apelação n. 200500146362. Relator: Desembargador Bernardo Moreira Garcez Neto. J. 24 jan 2006. Disponível em: <www.tj.rj.gov.br>. Acesso em: 05.10.2008.

RIO DE JANEIRO. Tribunal de Justiça do Estado do Rio de Janeiro. $2^{\mathrm{a}}$ Câmara Cível. Apelação n. 200500153638. Relator: Desembargador Carlos Eduardo da Fonseca Passos. J. 28 dez 2005. Disponível em: 〈www.tj.rj.gov.br〉. Acesso em: 05.10.2008.

RIO DE JANEIRO. Tribunal de Justiça do Estado do Rio de Janeiro. $6^{\text {a }}$ Câmara Cível. Apelação n. 200500116667. Relator: Desembargador Francisco de Assis Pessanha. J. 19 dez 2005. Disponível em: <www.tj.rj.gov.br>. Acesso em: 23.12.2008.

RIO DE JANEIRO. Tribunal de Justiça do Estado do Rio de Janeiro. $9^{a}$ Câmara Cível. Apelação n. 200500114469. Relator: Desembargador Ruyz Athayde Alcântara de Carvalho. J. 13 dez 2005. Disponível em: <www.tj.rj.gov.br>. Acesso em: 05.10.2008.

RIO DE JANEIRO. Tribunal de Justiça do Estado do Rio de Janeiro. 12 ${ }^{\text {a }}$ Câmara Cível. Apelação n. 200500136504. Relator: Desembargador Gamaliel Quinto de Souza. J. 13 dez 2005. Disponível em: <www.tj.rj.gov.br>. Acesso em: 05.10.2008. 
RIO DE JANEIRO. Tribunal de Justiça do Estado do Rio de Janeiro. $11^{\text {a }}$ Câmara Cível. Apelação n. 200500127062. Relator: Desembargador Claudio de Mello Tavares. J. 9 nov 2005. Disponível em: <www.tj.rj.gov.br>. Acesso em: 23.12.2008.

RIO DE JANEIRO. Tribunal de Justiça do Estado do Rio de Janeiro. 10ª Câmara Cível. Apelação n. 200500111190. Relator: Desembargador José Carlos Varanda. J. 8 nov 2005. Disponível em: <www.tj.rj.gov.br〉. Acesso em: 05.10.2008.

RIO DE JANEIRO. Tribunal de Justiça do Estado do Rio de Janeiro. 15ª Câmara Cível. Apelação n. 200500114638. Relator: Desembargador Ruyz José Pimentel Marques. J. 26 out 2005. Disponível em: <www.tj.rj.gov.br>. Acesso em: 05.10.2008.

RIO DE JANEIRO. Tribunal de Justiça do Estado do Rio de Janeiro. $3^{\text {a }}$ Câmara Cível. Apelação n. 200500107346. Relator: Desembargador Antonio Eduardo F. Duarte. J. 18 out 2005. Disponível em: <www.tj.rj.gov.br>. Acesso em: 05.10.2008.

RIO DE JANEIRO. Tribunal de Justiça do Estado do Rio de Janeiro. $2^{a}$ Câmara Cível. Apelação n. 200500114150. Relator: Desembargador Jessé Torres. J. 31 ago 2005. Disponível em: <www.tj.rj.gov.br>. Acesso em: 05.10.2008.

RIO DE JANEIRO. Tribunal de Justiça do Estado do Rio de Janeiro. 13 $3^{\text {a }}$ Câmara Cível. Apelação n. 200500109101. Relator: Desembargador Antonio José Azevedo Pinto. J. 17 ago 2005. Disponível em: <www.tj.rj.gov.br>. Acesso em: 05.10.2008.

RIO DE JANEIRO. Tribunal de Justiça do Estado do Rio de Janeiro. $8^{\text {a }}$ Câmara Cível. Apelação n. 200500108733. Relatora: Desembargadora Odete Knaack de Souza. J. 9 ago 2005. Disponível em: <www.tj.rj.gov.br>. Acesso em: 05.10.2008.

RIO DE JANEIRO. Tribunal de Justiça do Estado do Rio de Janeiro. $18^{a}$ Câmara Cível. Apelação n. 200500111048. Relator: Desembargador Marco Antonio Ibrahim. J. 9 ago 2005. Disponível em: <www.tj.rj.gov.br>. Acesso em: 05.10.2008.

RIO DE JANEIRO. Tribunal de Justiça do Estado do Rio de Janeiro. $4^{\mathrm{a}}$ Câmara Cível. Apelação n. 200400103512. Relator: Desembargador Mário dos Santos Paulo. J. 19 jul 2005. Disponível em: <www.tj.rj.gov.br>. Acesso em: 24.12.2008.

RIO DE JANEIRO. Tribunal de Justiça do Estado do Rio de Janeiro. $11^{a}$ Câmara Cível. Apelação n. 200500112653. Relatora: Desembargadora Marilene Melo Alves. J. 29 jun 2005. Disponível em: <www.tj.rj.gov.br>. Acesso em: 05.10.2008.

RIO DE JANEIRO. Tribunal de Justiça do Estado do Rio de Janeiro. $7^{\text {a }}$ Câmara Cível. Apelação n. 200400101512. Relator: Desembargador Ricardo Rodrigues Cardozo. J. 31 mai 2005. Disponível em: <www.tj.rj.gov.br>. Acesso em: 05.10.2008. Disponível em: <www.tj.rj.gov.br>. Acesso em: 05.10.2008.

RIO DE JANEIRO. Tribunal de Justiça do Estado do Rio de Janeiro. $12^{\mathrm{a}}$ Câmara Cível. Apelação n. 200500148850. Relator: Desembargador Gamaliel Quinto de Souza. J. 25 abr 2005. Disponível em: <www.tj.rj.gov.br>. Acesso em: 05.10.2008.

RIO DE JANEIRO. Tribunal de Justiça do Estado do Rio de Janeiro. $4^{\text {a }}$ Câmara Cível. Apelação n. 200500105263. Relator: Desembargador Reinaldo Pinto Alberto Filho. J. 6 abr 2005. Disponível em: <www.tj.rj.gov.br>. Acesso em: 05.10.2008. 
RIO DE JANEIRO. Tribunal de Justiça do Estado do Rio de Janeiro. 14 ${ }^{a}$ Câmara Cível. Apelação n. 200300120952. Relatora: Desembargadora Maria Christina Louchard de Góes. J. 14 fev 2005. Disponível em: <www.tj.rj.gov.br〉. Acesso em: 05.10.2008.

RIO DE JANEIRO. Tribunal de Justiça do Estado do Rio de Janeiro. 17 ${ }^{\text {a }}$ Câmara Cível. Apelação n. 200400109941. Relator: Desembargador Mauro Dickstein. J. 15 dez 2004. Disponível em: <www.tj.rj.gov.br>. Acesso em: 05.10.2008.

RIO DE JANEIRO. Tribunal de Justiça do Estado do Rio de Janeiro. $7^{\text {a }}$ Câmara Cível. Apelação n. 200400102222. Relator: Desembargador Ronaldo Rocha Passos. J. 18 nov 2004. Disponível em: <www.tj.rj.gov.br>. Acesso em: 05.10.2008.

RIO DE JANEIRO. Tribunal de Justiça do Estado do Rio de Janeiro. $2^{\mathrm{a}}$ Câmara Cível. Apelação n. 200400117032. Relatora: Desembargadora Elisabete Filizzola Assunção. J. 6 out 2004. Disponível em: <www.tj.rj.gov.br>. Acesso em: 05.10.2008.

RIO DE JANEIRO. Tribunal de Justiça do Estado do Rio de Janeiro. 14a Câmara Cível. Apelação n. 200300135408. Relator: Desembargador Walter Felippe D’ Agostino. J. 5 out 2004. Disponível em: <www.tj.rj.gov.br>. Acesso em: 05.10.2008.

RIO DE JANEIRO. Tribunal de Justiça do Estado do Rio de Janeiro. $18^{\text {a }}$ Câmara Cível. Apelação n. 200400102502. Relator: Desembargador Nascimento Póvoas. J. 28 set 2004. Disponível em: <www.tj.rj.gov.br>. Acesso em: 23.12.2008.

RIO DE JANEIRO. Tribunal de Justiça do Estado do Rio de Janeiro. 17ª Câmara Cível. Apelação n. 200400112910. Relator: Desembargador Rudi Loewenkron. J. 30 jun 2004. Disponível em: <www.tj.rj.gov.br>. Acesso em: 05.10.2008.

RIO DE JANEIRO. Tribunal de Justiça do Estado do Rio de Janeiro. $9^{a}$ Câmara Cível. Apelação n. 200400106281. Relator: Desembargador Marcus Tulius Alves. J. 17 set 2004. Disponível em: <www.tj.rj.gov.br>. Acesso em: 05.10.2008.

RIO DE JANEIRO. Tribunal de Justiça do Estado do Rio de Janeiro. $11^{\text {a }}$ Câmara Cível. Apelação n. 200400110830. Relator: Desembargador José Carlos de Figueiredo. J. $1^{\circ}$ set 2004. Disponível em: <www.tj.rj.gov.br>. Acesso em: 05.10.2008.

RIO DE JANEIRO. Tribunal de Justiça do Estado do Rio de Janeiro. $4^{\mathrm{a}}$ Câmara Cível. Apelação n. 200400105286. Relator: Desembargador Reinaldo Pinto Alberto Filho. J. 8 jun 2004. Disponível em: <www.tj.rj.gov.br>. Acesso em: 05.10.2008.

RIO DE JANEIRO. Tribunal de Justiça do Estado do Rio de Janeiro. 17 ${ }^{\text {a }}$ Câmara Cível. Apelação n. 200400103501. Relator: Desembargador Rudi Loewenkron. J. 19 mai 2004. Disponível em: <www.tj.rj.gov.br>. Acesso em: 05.10.2008.

RIO DE JANEIRO. Tribunal de Justiça do Estado do Rio de Janeiro. $7^{\mathrm{a}}$ Câmara Cível. Apelação n. 200300135251. Relator: Desembargador Maurício Caldas Lopes. J. 11 mai 2004. Disponível em: <www.tj.rj.gov.br>. Acesso em: 23.12.2008.

RIO DE JANEIRO. Tribunal de Justiça do Estado do Rio de Janeiro. $10^{\mathrm{a}}$ Câmara Cível. Apelação n. 200400100993. Relatora: Desembargadora Wany Couto. J. 20 abr 2004. Disponível em: <www.tj.rj.gov.br>. Acesso em: 05.10.2008. 
RIO DE JANEIRO. Tribunal de Justiça do Estado do Rio de Janeiro. 17ª Câmara Cível. Apelação n. 200300135773. Relator: Desembargador Rudi Loewenkron. J. 14 abr 2004. Disponível em: <www.tj.rj.gov.br>. Acesso em: 05.10.2008.

RIO DE JANEIRO. Tribunal de Justiça do Estado do Rio de Janeiro. $5^{\text {a }}$ Câmara Cível. Apelação n. 200300131061. Relator: Desembargador Humberto de Mendonça Manes. J. 9 mar 2004. Disponível em: <www.tj.rj.gov.br>. Acesso em: 05.10.2008.

RIO DE JANEIRO. Tribunal de Justiça do Estado do Rio de Janeiro. $11^{\text {a }}$ Câmara Cível. Apelação n. 200300132669. Relatora: Desembargadora Helena Belc Klausner. J. 3 mar 2004. Disponível em: <www.tj.rj.gov.br>. Acesso em: 23.12.2008.

RIO DE JANEIRO. Tribunal de Justiça do Estado do Rio de Janeiro. $11^{\text {a }}$ Câmara Cível. Apelação n. 200300133655. Relatora: Desembargadora Helena Belc Klausner. J. 28 jan 2004. Disponível em: <www.tj.rj.gov.br>. Acesso em: 23.12.2008.

RIO DE JANEIRO. Tribunal de Justiça do Estado do Rio de Janeiro. $11^{\text {a }}$ Câmara Cível. Apelação n. 200300132610. Relator: Desembargador Claudio de Mello Tavares. J. 21 jan 2004. Disponível em: <www.tj.rj.gov.br>. Acesso em: 23.12.2008.

RIO DE JANEIRO. Tribunal de Justiça do Estado do Rio de Janeiro. Órgão Especial. Arguição de Inconstitucionalidade n. 46. Relator: Desembargador Ronald Valladares. J. 28 ago 2006. Disponível em: <www.tj.rj.gov.br>. Acesso em: 05.10.2008.

RIO DE JANEIRO. Tribunal de Justiça do Estado do Rio de Janeiro. $7^{\mathrm{a}}$ Câmara Cível. Arguição de Inconstitucionalidade n. 15. Relator: Desembargador Silvio Teixeira. J. 17 abr 2006. Disponível em: <www.tj.rj.gov.br>. Acesso em: 23.12.2008.

RIO DE JANEIRO. Tribunal de Justiça do Estado do Rio de Janeiro. Órgão Especial. Argüição por Inconstitucionalidade n. 18. Relator: Desembargador Ronald Valladares. J. 25 jul 2005. Disponível em: <www.tj.rj.gov.br>. Acesso em: 05.10.2008.

RIO DE JANEIRO. Tribunal de Justiça do Estado do Rio de Janeiro. 16 Câmara Cível. Duplo Grau Obrigatório no Mandado de Segurança n. 695. Relator: Desembargador Mario Robert Mannheimer. J. 3 out 2006. Disponível em: 〈www.tj.rj.gov.br〉. Acesso em: 05.10.2008.

RIO DE JANEIRO. Tribunal de Justiça do Estado do Rio de Janeiro. $17^{\text {a }}$ Câmara Cível. Duplo Grau Obrigatório n. 200500901192. Relatora: Desembargadora Rosita Maria de Oliveira Netto. J. 28 jun 2006. Disponível em: 〈www.tj.rj.gov.br>. Acesso em: 23.12.2008.

RIO DE JANEIRO. Tribunal de Justiça do Estado do Rio de Janeiro. $2^{\mathrm{a}}$ Câmara Cível. Duplo Grau Obrigatório n. 200400900277. Relator: Desembargador Antonio Saldanha Palheiro. J. 23 jun 2004. Disponível em: <www.tj.rj.gov.br〉. Acesso em: 05.10.2008.

RIO DE JANEIRO. Tribunal de Justiça do Estado do Rio de Janeiro. Órgão Especial. Representação por Inconstitucionalidade n. 20. Relator: Desembargador Nilton Mondego de Carvalho Lima. J. 3 nov 2003. Disponível em: 〈www.tj.rj.gov.br〉. Acesso em: 05.10.2008. 